\author{
UNIVERSIDADE DE BRASÍLIA \\ FACULDADE DE EDUCAÇÃO \\ PROGRAMA DE PÓS-GRADUAÇÃO EM EDUCAÇÃO
}

WELLINGTON AGUIAR DE MELO

INFLUÊNCIA DA PRÁTICA DO XADREZ ESCOLAR NO RACIOCÍNIO INFANTIL 
UNIVERSIDADE DE BRASÍLIA

FACULDADE DE EDUCAÇÃO

PROGRAMA DE PÓS-GRADUAÇÃO EM EDUCAÇÃO

\section{INFLUÊNCIA DA PRÁTICA DO XADREZ ESCOLAR NO RACIOCÍNIO INFANTIL}

Wellington Aguiar de Melo

Dissertação de mestrado submetida ao Programa de Pós-Graduação em Educação da Faculdade de Educação da Universidade de Brasília, como requisito parcial à obtenção do título de Mestre em Educação.

Orientador: Prof. Dr. Antônio Villar Marques de Sá

Co-orientador: Prof. Dr. Luiz Pasquali 
Ficha catalográfica elaborada automaticamente,

com os dados fornecidos pelo(a) autor(a)

A499i

Aguiar de Melo, Wellington

Influência da prática do xadrez escolar no raciocínio infantil / Wellington Aguiar de Melo; orientador Antônio Villar Marques de Sá; co orientador Luiz Pasquali. -- Brasília, 2015. $126 \mathrm{p}$.

Dissertação (Mestrado - Mestrado em Educação) -Universidade de Brasília, 2015.

1. Xadrez. 2. Raciocínio. 3. Xadrez Escolar. 4. Raciocínio Infantil. I. Villar Marques de Sá, Antônio, orient. II. Pasquali, Luiz, co-orient. III. Título. 
UNIVERSIDADE DE BRASÍLIA

FACULDADE DE EDUCAÇÃO

PROGRAMA DE PÓS-GRADUAÇÃO EM EDUCAÇÃO

\title{
INFLUÊNCIA DA PRÁTICA DO XADREZ \\ ESCOLAR NO RACIOCÍNIO INFANTIL
}

\author{
Brasília, 17 de abril de 2015
}

\section{Banca Examinadora de Defesad dẹ Diģ̧ertação de Mestrado

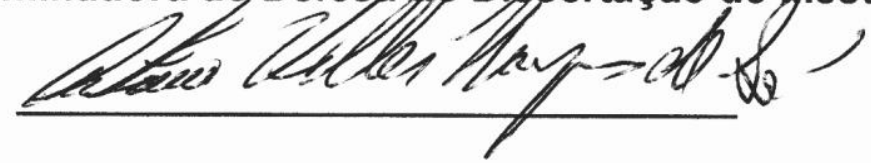

Prof. Dr. Antônio Villar Marques de Sá

Faculdade de Educação - Universidade de Brasília - UnB

(Orientador)

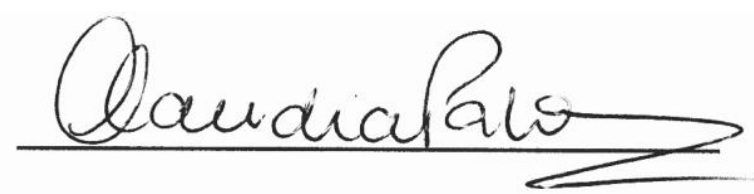

Profa. Dra. Claudia Márcia Lyra Pato

Faculdade de Educação - Universidade de Brasília - UnB

(Membro Interno)

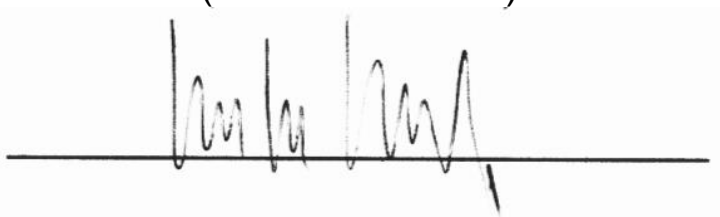

Prof. Dr. Lino de Macedo

Instituto de Psicologia - Universidade de São Paulo - USP

(Membro Externo)

Profa. Dra. Maria Abádia da Silva

Faculdade de Educação - Universidade de Brasília - UnB

(Membro Suplente) 


\section{RESUMO}

O xadrez é considerado pelo senso comum uma poderosa ferramenta para se desenvolver a concentração, a paciência e a perseverança, assim como a criatividade, o raciocínio, a intuição, a memória etc. Porém, muitos põem em xeque esses benefícios, devido à carência de suporte empírico e dos graves problemas metodológicos de estudos anteriores. Em meio a esse fogo cruzado, o presente trabalho teve como objetivo avaliar se a prática do xadrez tem influência no desenvolvimento do raciocínio em crianças. Foram selecionados aleatoriamente 36 sujeitos com idade entre 7 e 8 anos de uma escola pública da zona rural do Distrito Federal. Os sujeitos selecionados foram divididos em três grupos com 12 sujeitos cada. O grupo experimental (GEX) frequentou duas aulas de xadrez por semana, com duração de uma hora cada, enquanto o grupo controle 1 (GC1) frequentou aulas de reforço e o grupo controle 2 (GC2) não recebeu nenhuma intervenção. Os sujeitos foram avaliados antes e após a intervenção por meio do Teste Não Verbal de Raciocínio Infantil (PASQUALI, 2005), visando confirmar ou rejeitar a hipótese de que o GEX irá obter ganhos maiores que o GC1 e GC2. Buscou-se também verificar se a expertise enxadrística influencia nos níveis de raciocínio, utilizando como parâmetro a pontuação obtida em um campeonato realizado ao final do estudo. Por último, buscou-se verificar se existem diferenças significativas entre sexo masculino e feminino. Em relação às diferenças entre os sexos, os dados coletados mostraram, adotando um nível de significância de $5 \%$, que as meninas obtiveram ganho significante entre o pré e o pós-teste $(p<0,0213)$. O mesmo não aconteceu entre os meninos $(p<0,0747)$. Em relação à performance enxadrística, foi possível inferir que não houve correlação entre os dados obtidos, pois o valor encontrado na correlação de Pearson ( $r$ ) foi de $+0,1753$. Em relação aos escores obtidos no TNVRI, os indivíduos que frequentaram aulas de xadrez obtiveram ganhos superiores no Fator Geral quando comparados aos indivíduos que frequentaram aulas de reforço e aos indivíduos que não foram submetidos à intervenção extra. O ganho médio no grupo GEX foi de 7,67 pontos. Já nos grupos GC1 e GC2 foi de 3,33 e 2,08, respectivamente. Podemos ver que o GEX obteve um ganho superior ao GC1 e ao GC2. Porém, adotando o nível de significância em $5 \%$, foi possível afirmar que os ganhos obtidos entre o pré e pós-teste, nos três grupos, foram estatisticamente iguais $(p<0,129)$. Ou seja, mesmo que o GEX tenha apresentado uma tendência de ganhos superiores aos demais, os dados não foram suficientes para comprovar estatisticamente a diferença de ganhos entre os três grupos.

Palavras-chave: Xadrez. Raciocínio infantil. Xadrez escolar. TNVRI. 


\begin{abstract}
Chess is considered by common sense a powerful tool to develop concentration, patience and perseverance, as well as creativity, reasoning, intuition, memory etc. However, many put a risk to these benefits, due to the lack of empirical support and serious methodological problems of previous studies. Amid this crossfire, this study aimed to evaluate if the practice of chess influences the development of reasoning in children. We randomly selected 36 subjects aged between 7 and 8 years of a rural public school in Distrito Federal. The selected subjects were divided into three groups of 12 subjects each. The experimental group (GEX) attended two chess lessons per week, lasting one hour each, while the control group 1 (GC1) attended tutoring classes and the control group 2 (GC2) received no intervention. Subjects were evaluated before and after the intervention through the Nonverbal Test of Child Reasoning (Pasquali, 2005), aiming to confirm or reject the hypothesis that the GEX will get greater gains than the GC1 and GC2. We tried to also check if the chess expertise influences the levels of reasoning, using as parameter the score in a championship held at the end of the study. Finally, we sought to determine whether there are significant differences between male and female. Regarding the differences between the sexes, the data collected demonstrated, adopting a $5 \%$ significance level, that girls got significant gain between pre and post-test $(p<0.0213)$. Not so among boys $(p<0.0747)$. Regarding chess performance, it was possible to infer that there was no correlation between the data obtained as the value found in the Pearson correlation $(r)$ was +0.1753 . As to the scores obtained in TNVRI, individuals who attended chess classes obtained higher gains in General Factor when compared to individuals who attended remedial classes and individuals who did not undergo extra intervention. Average increase in GEX group was 7.67 points. Already in GC1 and GC2 groups was 3.33 and 2.08, respectively. We can see that the GEX obtained a gain higher than the GC1 and GC2. However, adopting the significance level of $5 \%$ was possible to state that the gains obtained in the pre and post-test, the three groups were statistically similar $(p<0.129)$. That is, even if the GEX has shown a trend of higher gains to others, the data were not sufficient to statistically prove the earnings difference between the three groups.
\end{abstract}

Keywords: Chess. Child Reasoning. Schollar Chess. TNVRI. 


\section{LISTA DE FIGURAS}

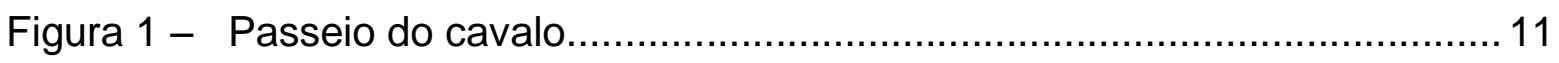

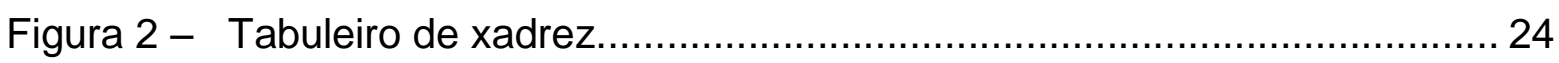

Figura 3 - Exemplo de figura que compõe o TNVRI......................................... 62

Figura 4 - Figura utilizada como exemplo "a" no TNVRI......................................67

Figura 5 - Modelo de Matriz presente no WISC-R.............................................. 91 


\section{LISTA DE GRÁFICOS}

Gráfico 1 - Gráfico ilustrativo do comportamento de um bloxplot....................... 70

Gráfico 2 - Gráfico 2 - Quantidade de indivíduos de cada sexo por grupo...........76

Gráfico 3 - Comparação de resultados PreT e PosT - Fator 2 - GC1 ..................78

Gráfico 4 - Comparação de resultados PreT e PosT - Fator 1 - GC1 ..................79

Gráfico 5 - Boxplot do Fator Geral PreT por grupo.......................................... 79

Gráfico 6 - Boxplot do Fator Geral PosT por grupo........................................ 80

Gráfico 7 - Boxplot da diferença entre o Fator Geral Antes e Fator Geral

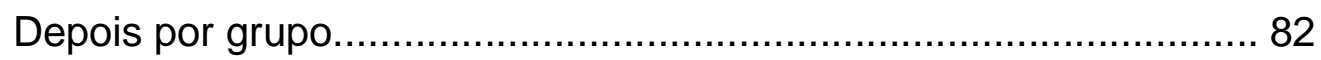

Gráfico 8 - Comparação entre os escores do PosT - Fator Geral - GEX com as pontuações obtidas no campeonato.............................................. 86

Gráfico 9 - Comparação entre os escores do PosT - Fator Geral - GEX com as pontuações obtidas no campeonato

Gráfico 10 - Comparação de escores - PreT e PosT - TCS: Subteste "Memória" - Grupo xadrez

Gráfico 11 - Comparação de escores - PreT e PosT - TNVRI: Fator Geral GEX. 89

Gráfico 12 - Comparação das médias dos escores PreT e PosT - Fator Geral - Sexo feminino e masculino 99

Gráfico 13 - Comparação de ganhos entre PreT e PosT no Fator Geral 100 


\section{LISTA DE TABELAS}

Tabela 1 - Compilação de estudos enxadrísticos em comparação com o experimento ideal.

Tabela 2 - Resultados obtidos por De Groot (1978) em seu estudo, organizados de acordo com a quantidade/porcentagem de erros e acertos na

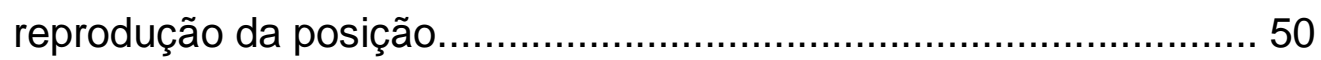

Tabela 3 - Tabela da Análise de Variância.................................................... 75

Tabela 4 - Frequências e porcentagens da variável sexo.................................. 76

Tabela 5 - Frequências e porcentagens da variável grupo................................77

Tabela 6 - Principais estatísticas descritivas para o Fator 1 e 2 PreT e o Fator 1

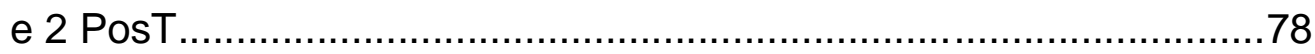

Tabela 7 - Principais estatísticas descritivas para o Fator Geral PreT e Fator

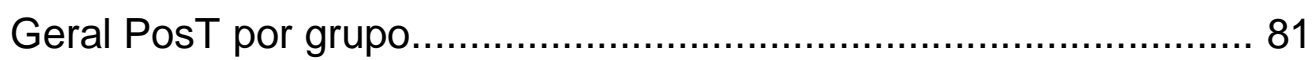

Tabela 8 - Comparação de ganhos entre os grupos......................................... 82

Tabela 9 - Tabela da Análise de Variância da diferença entre o Fator Geral Antes e Fator Geral Depois.......................................................... 83

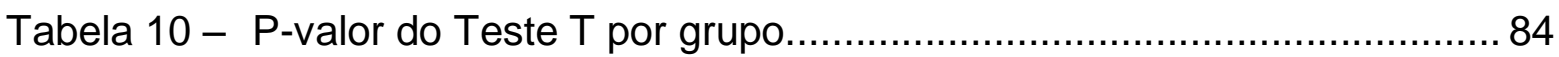

Tabela 11 - Escores TNVRI e pontuação do campeonato.................................... 85

Tabela 12 - Sumário estatístico - Teste $t$ - Test of Cognitive Skills - TCS............88

Tabela 13 - Progressão da porcentagem de mulheres registradas na KNSB (Federação Real Holandesa de Xadrez)......................................... 93 


\section{SUMÁRIO}

1 INTRODUÇÃO

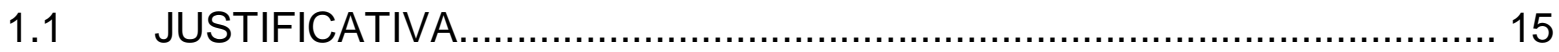

$2 \quad$ EIXO TEÓRICO

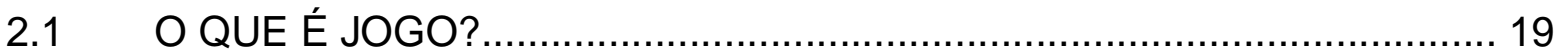

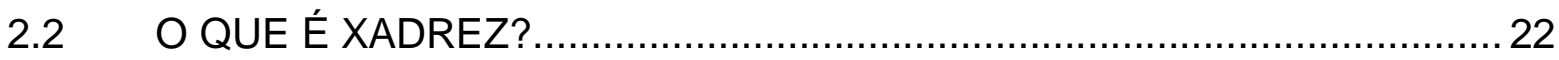

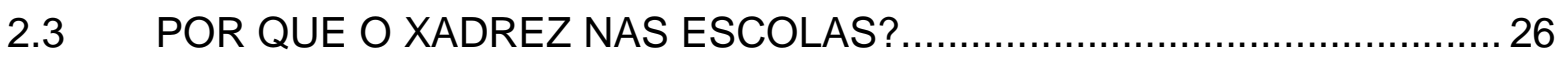

2.3.1 O que é competição?.............................................................................. 33

2.3.2 O que é autonomia?...................................................................... 36

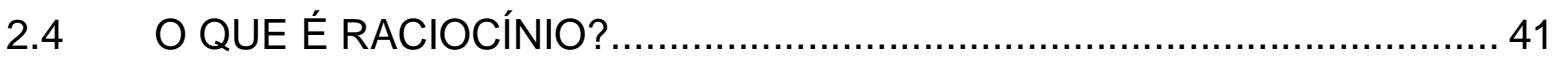

2.4.1 A importância da memória para o raciocínio....................................... 47

2.4.2 A importância do fator emocional na tomada de decisões................... 51

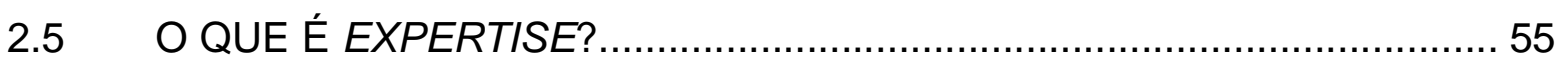

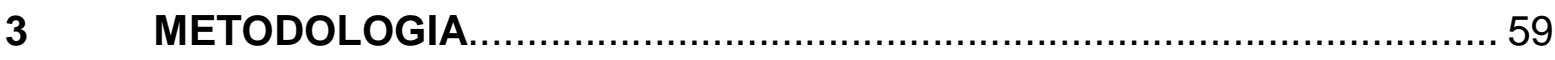

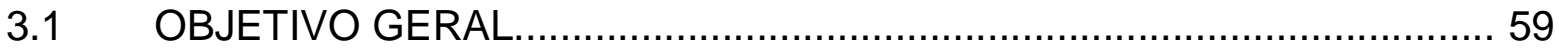

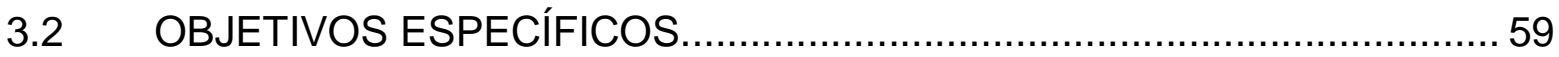

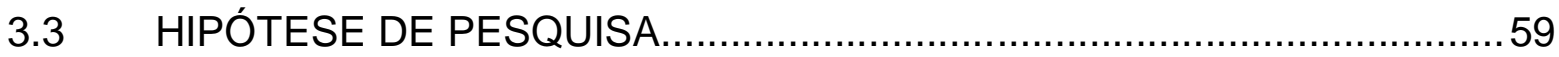

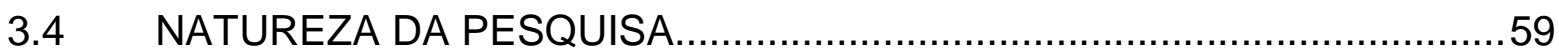

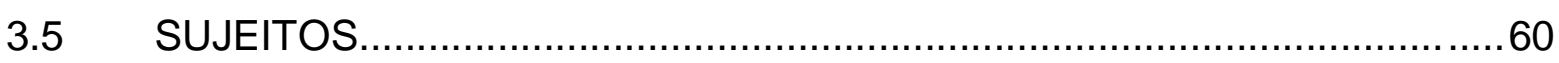

3.5.1 Critérios de inclusão na pesquisa...................................................... 61

3.5.2 Critérios de exclusão da pesquisa....................................................... 61

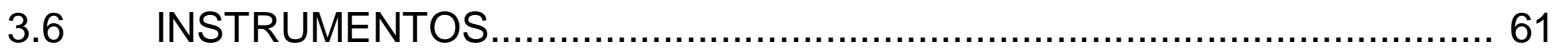

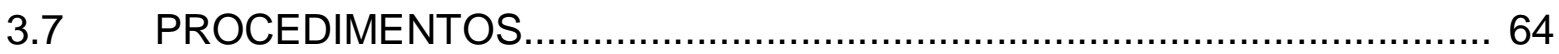

3.7.1 Aplicações do pré-teste (PreT) e do pós-teste (PosT).......................... 65

3.7.2 Diferenças de gênero................................................................ 68

3.7.3 Pontuações no campeonato.............................................................. 68

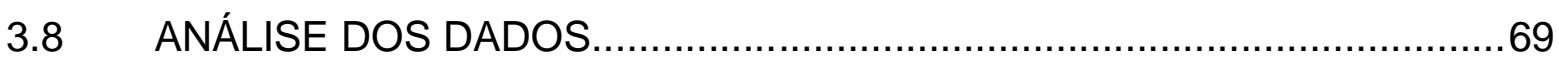

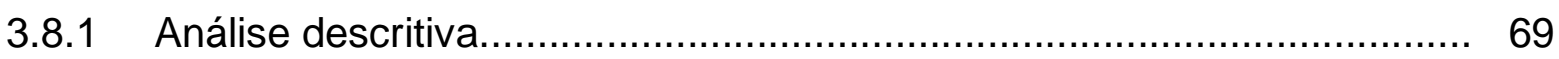

3.8.2 Teste de hipótese..................................................................... 71

3.8.2.1 Teste T para amostras dependentes............................................... 72

3.8.2.2 Teste de Wilcoxon para amostras dependentes................................... 73

3.8.3 Análise de Variância.............................................................................. 74 
$4 \quad$ RESULTADOS

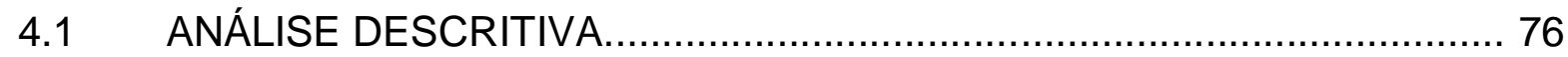

4.2 ANÁLISE DE VARIÂNCIA DA DIFERENÇA ENTRE O FATOR GERAL ANTES E O FATOR GERAL DEPOIS....................................... 82

4.3 COMPARAÇÕES DE MÉDIAS ENTRE O FATOR GERAL PRET

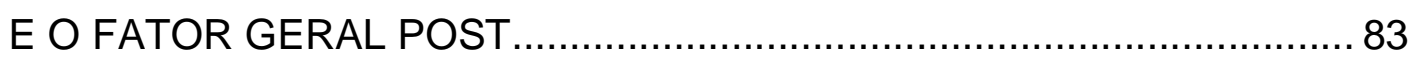

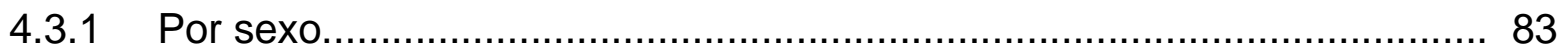

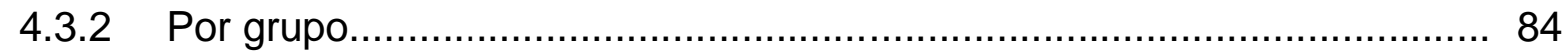

4.4 CORRELAÇÃO ENTRE EXPERTISE ENXADRÍSTICA E

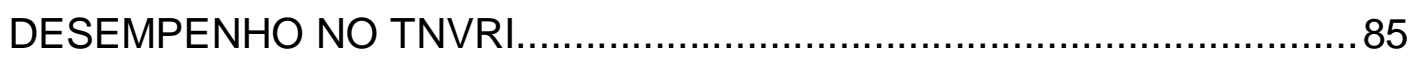

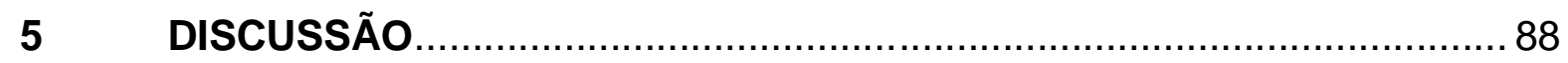

5.1 O QUE DISSERAM OS ESTUDOS SEMELHANTES? .......................... 88

5.2 EXISTEM DIFERENÇAS DE RACIOCÍNIO ENTRE OS SEXOS?.............92

5.3 EXISTE CORRELAÇÃO ENTRE EXPERTISE ENXADRÍSTICA E

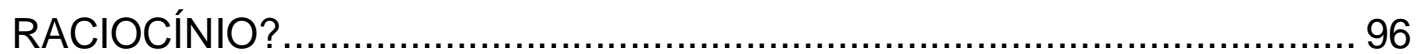

5.4 AFINAL, O XADREZ DESENVOLVE O RACIOCÍNIO?............................99

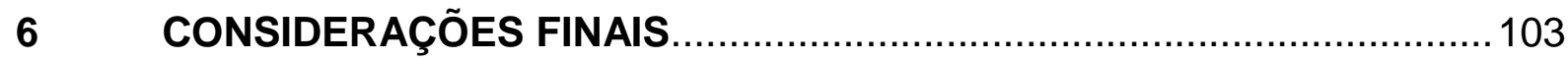

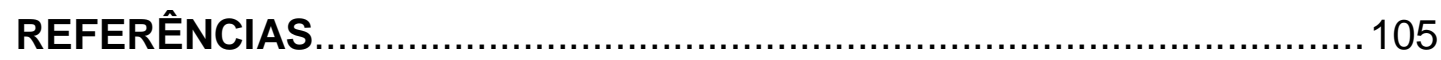

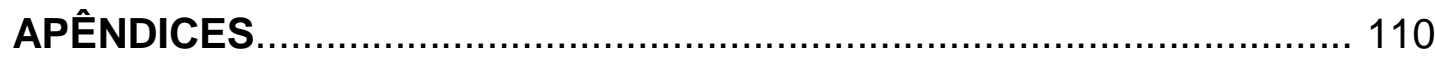




\section{INTRODUÇÃO}

O xadrez é algo mais que um jogo. É uma diversão intelectual que tem algo de arte e muito de ciência (CAPABLANCA, 2002, p. 11).

O xadrez é uma arte? Uma ciência? Alguns afirmam que ambos. Mas, sejamos honestos, é realmente apenas um jogo (DAUVERGNE, 2007, p. 11).

Quem está certo? José Raúl Capablanca (2002), renomado enxadrista cubano, que resumiu, nessa frase, o que o xadrez representa para seus amantes e admiradores, a fonte de todo o fascínio, proporcionado aos que se deleitam do prazer em jogar ou admirar uma bela partida de xadrez. Ou será Peter Dauvergne (2007), professor canadense de Ciência Política, grande mestre em xadrez, que realizou diversos estudos sobre os benefícios advindos da prática do xadrez?

Encarar o xadrez como ciência é uma tarefa há muito explorada. Segundo Edward Lasker (1999, p. 184):

A literatura técnica do jogo atingiu proporções espantosas. Dificilmente passa um ano sem que apareçam dezenas de novos livros de xadrez, escritos em todos os idiomas falados pelo crescente exército dos aficionados do jogo. Mais de dez mil volumes contêm a coleção J. G. White de livros de xadrez, guardada na Biblioteca Pública de Cleveland! Creio que isso supera o número de livros impressos sobre todos os outros jogos em conjunto.

O "Passeio do cavalo" é um dos problemas matemáticos mais famosos do xadrez, no qual o desafio é mover a peça por todas as casas do tabuleiro, de acordo com sua movimentação característica, sem repetir nenhuma casa. Devido à movimentação peculiar do cavalo (que anda duas casas para frente e uma para o lado, formando um "L") e da quantidade de casas no tabuleiro (64, sendo 32 brancas e 32 pretas), essa não é uma tarefa muito fácil. Inúmeros matemáticos se propuseram a estudar esse problema, tornando-o um marco para a junção entre o xadrez e os estudos científicos. 
Figura 1 - Passeio do cavalo
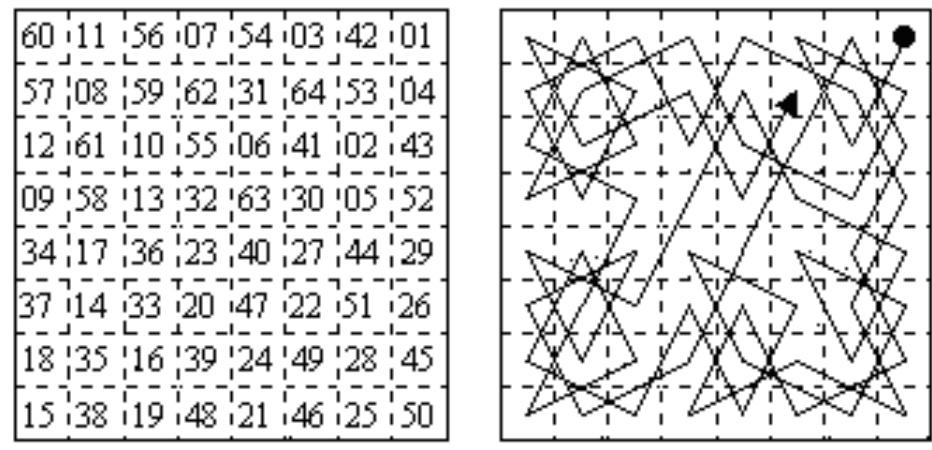

Fonte: HILL; TOSTADO, 2004, p. 4.

Da mesma forma, a arte no jogo de xadrez é também evidenciada desde os primórdios de sua criação. Huizinga (2012, p. 177) afirmou que "Não resta dúvida que o ritmo e a harmonia são fatores comuns, em sentido exatamente idêntico, à poesia, à música e ao jogo". Prova de tal ligação entre xadrez, arte, música e, como foi tratado inicialmente, matemática é a comum incidência de prodígios nessas áreas. Sobre tal assunto, Edward Lasker (1999, p. 163) escreveu em seu livro que:

\begin{abstract}
Na música, no xadrez ou na matemática, a experiência não é necessária. Ali as crianças podem brilhar, porque os dotes nativos são o fator dominante. A sensibilidade estética e a capacidade de pensar logicamente são sem dúvida qualidades natas. De outra forma, como poderia Mozart ter composto um minueto, escrevendo-o realmente, antes de completar quatro anos de idade? Como poderia Gauss, antes dos três anos de idade e antes de saber escrever, ter corrigido o total de uma comprida soma que via seu pai fazer? Como poderia Sammy Reshevsky ter jogado dez partidas de xadrez simultaneamente com apenas seis anos de idade?
\end{abstract}

Portanto, restam-nos ainda algumas dúvidas: A habilidade enxadrística é uma característica nata? E, mais ainda, "a capacidade de pensar logicamente", como afirmou Edward Lasker (1999, p. 163), também o é? É impossível treinar, ao longo da vida, o pensamento lógico? A discussão sobre a existência e também sobre a influência do talento no xadrez requer um outro estudo muito mais aprofundado e, portanto, não será abordado neste momento.

O mesmo Dauvergne (2007), que inicialmente reduziu o xadrez a um simples jogo, afirmou que não importa a idade, o xadrez é uma poderosa ferramenta para se desenvolver a concentração, a paciência e a perseverança, como também a criatividade, intuição, memória, e, segundo ele, mais importante, a habilidade de analisar e deduzir a partir de um conjunto de princípios gerais, aprendendo a tomar decisões difíceis e a resolver problemas de maneira flexível. Ou seja, segundo 
Dauvergne (2007), a habilidade mais importante desenvolvida pelo xadrez é justamente o raciocínio.

Considero a definição de raciocínio apresentada por Sternberg (2010, p. 446) como a mais condizente à utilizada no xadrez. Segundo ele, "Raciocínio é o processo de chegar a conclusões com base em princípios e provas". O julgamento e a tomada de decisão, tão importantes no xadrez, baseiam-se na seleção da melhor opção dentre várias (ou de apenas duas) opções disponíveis. Para se chegar à seleção da "melhor opção", é preciso raciocinar, ou seja, chegar à conclusão com base em princípios e provas. Porém, no xadrez, tal tarefa não é tão simples quanto parece. De Groot (1978), psicólogo e também mestre em xadrez, se propôs a estudar os processos de pensamento e raciocínio utilizados por grandes jogadores em uma partida de xadrez. De Groot (1978), em seu estudo, apresentou uma determinada posição em um tabuleiro de xadrez e deu a seguinte tarefa aos grandes jogadores os quais entrevistou: determinar o melhor movimento a se fazer e tentar verbalizar a linha de pensamento utilizada para se chegar a tal conclusão. Com isso, podia-se obter os "princípios e provas" citados por Sternberg (2010). Porém, como afirmei anteriormente, no xadrez tal tarefa não é tão simples. Como afirmou o próprio De Groot (1978, p. 31, tradução nossa):

\footnotetext{
Por causa do tempo de pensamento limitado e da necessidade de resolver tudo em sua cabeça, o jogador muitas vezes não pode fornecer uma prova, mesmo que uma análise possa. Deve ser mantido em mente, por outro lado, que, numa posição de xadrez, o que pode e deve ser provado não é dado como em um problema matemático. O jogador deve descobrir isso por si mesmo, o processo de pensamento envolve tanto a pesquisa e raciocínio, tanto selecionando um movimento como construindo uma argumentação para a escolha. Assim, é relativamente raro para um processo de pensamento constituir uma prova rigorosa. $\mathrm{Na}$ maioria dos casos, um movimento é jogado sem certeza absoluta que ele realmente é o melhor movimento.
}

Dito dessa forma, parece-nos que na maioria dos casos cada lance é executado com base em uma "crença". Apesar de parecer uma palavra demasiadamente forte, além de fora de contexto, crer que sua decisão reflete o melhor lance a ser executado define grande parte das ações tomadas por um jogador de xadrez. A posição das peças sugere o melhor lance a ser executado no momento, assim como o próximo lance do adversário. Dewey $(1959$, p. 21) define essa situação não como "raciocínio", mas sim, com uma palavra mais abrangente: pensamento. De acordo com ele, pensamento é a "operação em virtude da qual os 
fatos presentes sugerem outros fatos (ou verdades), de tal modo que nos induzam a crer no que é sugerido".

Porém, a palavra crença não deve ser utilizada levianamente. De acordo com o próprio Dewey, o fato de crer (ou não crer) em algo não significa uma atitude impensada ou imprudente, ou seja, um "lance de sorte“. A crença é criada "por intermédio de alguma outra coisa que lhe sirva de testemunho, evidência, prova, documento, garantia, em suma, de fundamento da crença” (DEWEY, 1959, p. 21).

É justamente nesse processo de aquisição de tal evidência que o xadrez mostra sua importância para o desenvolvimento do raciocínio. A importância não está na escolha (e acerto) do melhor lance, mas sim no processo mental complexo utilizado na busca por tal lance. O fato de, apenas por meio do raciocínio, não ser possível fornecer provas consistentes que justifiquem o lance escolhido não diminui os benefícios desse processo.

Ao observar isso, Dauvergne (2007), e muitos outros antes dele, afirmaram que o xadrez é uma das ferramentas educacionais mais poderosas que temos acesso para desenvolver a mente de uma criança. No mesmo sentido, Sá (2012, p. 170) explicitou:

\footnotetext{
A importância do jogo para o desenvolvimento humano tem sido objeto de estudo dos mais diversos campos do conhecimento. A atividade lúdica foi enfocada sob o ponto de vista filosófico (Pascal, Alain, Henriot, Schopenhauer, Nietzsche, Bataille, Sartre), sociológico (Huizinga, Hirn, Caillois, Brougère), psicanalítico ( $S$. Freud, A. Freud, Klein, Winnicott, Charles Nicolas, Enriquez), psicológico (Gross, Claparède, Chateau, Piaget, Vigotski) e pedagógico (Rosseau, Pestalozzi, Frobel, Montessori, Decroly, Freinet, Michelet).
}

A utilização do xadrez para o desenvolvimento de habilidades cognitivas tem despertado o interesse das escolas, que a cada dia se rendem aos seus benefícios e procuram incluir atividades enxadrísticas em sua rotina. Seja de forma discreta, inserindo-o apenas como uma atividade extracurricular, esporádica e voluntária, ou de forma contundente, fazendo-o parte integrante do currículo regular, a sua presença nas salas de aula é cada vez mais visível. A meu ver, os principais fatores que tornam o xadrez uma atividade tão valorosa nas salas de aula são:

a) todas as características físicas que classificam uma pessoa como "boa" ou "ruim" em algum esporte são irrelevantes no xadrez. Alto ou baixo, forte ou fraco, menino ou menina, jovem ou velho, todos são iguais diante de um tabuleiro de xadrez; 
b) o xadrez é um terreno fértil para o desenvolvimento da autoestima e da motivação, pois proporciona a oportunidade de vitória para crianças que, diante do fracasso em outras modalidades esportivas devido ao seu porte físico ou habilidades motoras, se viam desmotivadas, não apenas no âmbito esportivo, mas na esfera acadêmica como um todo;

c) por mais complexo que pareça, é um jogo com regras simples e bem definidas, sem necessidade de interpretação. Crianças de 7 anos aprendem facilmente as regras básicas. Até mesmo crianças de 4 ou 5 anos podem jogar;

d) por mais que a criança aprenda as regras e dicas básicas para se jogar e, consequentemente, ganhar um jogo, é impossível (pelo fato de não existir até o presente momento) um caminho certo para a vitória, uma "fórmula". Cada jogo é um universo diferente, cada um deve aprender a "ler" o jogo que tem diante de si e saber que caminho deve seguir;

e) a facilidade em se trabalhar os mais diversos conteúdos e conhecimentos de forma lúdica por meio do xadrez. Brincando é possível se ensinar história, geografia, sociologia, português e matemática, potencializando o processo de ensino-aprendizagem de conteúdos presentes em cada uma dessas e de outras disciplinas.

Porém, mesmo com todos esses benefícios explicitados sobre a prática do xadrez, além de toda preocupação e fascinação de diferentes cientistas e pesquisadores sobre $\mathrm{o}$ assunto, alguns aspectos relativos aos benefícios do xadrez ainda carecem de estudos. Campitelli e Gobet (2007, p. 183) põem em xeque todas as afirmações sobre os benefícios pedagógicos do xadrez:

\footnotetext{
Em todas as atividades anteriores existe, implicitamente, a crença de que as habilidades adquiridas jogando o xadrez podem transferir-se a outros campos. Tal crença está baseada em evidências contundentes? O valor educativo do xadrez é um fato empírico bem-estabelecido ou os jogadores e professores pensam que 0 xadrez oferece vantagens educativas por seu amor cego ao jogo?
}

Portanto, por mais que inúmeros estudos e incessantes resultados positivos sejam alcançados, ainda se enfrentam críticas e se encontram lacunas ao afirmar, com alto grau de certeza, que o xadrez desenvolve habilidades cognitivas em quem o pratica. 


\subsection{JUSTIFICATIVA}

É cada dia mais imperativa a necessidade de variar métodos e estratégias utilizados em sala de aula para potencializar o processo de ensino-aprendizagem. Essa demanda surge devido à mudança no perfil dos alunos que encontramos nas escolas atualmente. Cada dia mais críticos demonstram resistência às aulas "tradicionais", ou seja, um professor de pé, de frente a um quadro negro, ministrando uma aula expositiva, monótona e conteudista. Ao aluno, cabe apenas "ver, ouvir e registrar", intercalando raros momentos de interação com o conhecimento que lhe é exposto. Segundo os Parâmetros Curriculares Nacionais (PCN) (BRASIL, 1997), o aluno deve ter as seguintes habilidades, ao final do ensino fundamental:

\footnotetext{
Utilizar diferentes linguagens - verbal, matemática, gráfica, plástica e corporal - como meio para produzir, expressar e comunicar suas ideias, interpretar e usufruir das produções culturais, em contextos públicos e privados, atendendo a diferentes intenções e situações de e tratando de resolvê-los, utilizando para isso o pensamento lógico, a criatividade, a intuição, a capacidade e análise crítica, selecionando procedimentos e verificando sua adequação (BRASIL, 1997, p. 69).
}

Fica clara a necessidade da utilização de métodos complementares que auxiliem o professor e o aluno a alcançarem tais objetivos, em que a participação do aluno seja mais efetiva e seu pensamento crítico seja cada dia mais estimulado (RODRIGUES, 2013, p. 17).

Em busca do desenvolvimento de tais habilidades, o xadrez tem sido utilizado como ferramenta pedagógica complementar no processo de ensino-aprendizagem em muitas escolas por todo o mundo. Rodrigues (2013, p. 18) afirma que o xadrez, por ser um jogo em que o fator sorte não existe, mas sim o planejamento e a tomada de decisões baseada em fatores mensuráveis, "[...] o torna especialmente desafiador e cria um ambiente propício ao desenvolvimento de diversas habilidades".

A Lei de Diretrizes e Bases da Educação Nacional (LDB) no 9.394/96, em seu artigo 26 e artigo 27 (incisos de I a IV) (BRASIL, 2010, p. 9 e 10), abre espaço para os professores que desejam utilizar o jogo de xadrez como parte diversificada dos currículos e também como promoção do desporto:

Art. 26. Os currículos do ensino fundamental e médio devem ter uma base nacional comum, a ser complementada, em cada sistema de ensino e estabelecimento escolar, por uma parte diversificada, exigida pelas 
características regionais e locais da sociedade, da cultura, da economia e da clientela.

Art. 27. Os conteúdos curriculares da educação básica observarão, ainda, as seguintes diretrizes: I - a difusão de valores fundamentais ao interesse social, aos direitos e deveres dos cidadãos, de respeito ao bem comum e à ordem democrática;

II - consideração das condições de escolaridade dos alunos em cada estabelecimento; III - orientação para o trabalho; IV - promoção do desporto educacional e apoio às práticas desportivas não- formais.

Em inúmeros países, o xadrez já é visto como uma ferramenta pedagógica de valor fundamentado cientificamente a ponto de se tornar uma política pública, sendo inserido nos mais variados níveis escolares. Sá (2012) mostra como em diversos países, tais como a Alemanha, Argentina, Canadá, Cuba e Estados Unidos, a prática já se encontra, de certa forma, consolidada dentro das escolas. Na Argentina, 18.000 alunos que vivem no estado de Santa Fé e estão entre $\circ 5^{\circ}$ e $\circ 7^{\circ}$ ano do ensino fundamental recebem o ensino obrigatório de xadrez educativo, sancionado por leis do estado. O "Plan massivo de enseñanza del ajedrez em las escuelas primarias", criado em 1964, em Cuba, foi o precursor da massificação do jogo nas escolas, que hoje abrange 450.000 alunos entre o $3^{0}$ e $07^{\circ}$ ano do ensino fundamental. No Brasil, a experiência mais famosa e de maior sucesso foi a da inclusão do xadrez na cidade de Curitiba, Paraná. A Secretaria Municipal de Educação atende 90 das 168 escolas públicas municipais com um programa de ensino, proporcionando a possibilidade de praticar o jogo para mais de 25.000 alunos (W. SILVA, 2010).

Um dos pontos que favorece a inclusão do xadrez nas escolas é a sua capacidade de atender às necessidades de um público tão heterogêneo, mas de uma forma em que seja respeitada a individualidade do aluno. As mentes de jovens ou idosos, ricos ou pobres, meninos ou meninas podem se desafiar igualmente, sem que um ou outro já inicie o jogo com uma vantagem determinada por gênero, idade ou porte físico. Porém, isso não seria o suficiente para justificar a inclusão do xadrez nas escolas. Sá, Rezende Júnior e Melo (2013, p. 277) afirmaram que:

O xadrez também ajuda a construir a autoconfiança e a autoestima, devido à sua competitividade e à possibilidade da derrota, tão temida por muitos, mas vivenciadas por todos. Também contribui potencialmente às crianças menos talentosas a possibilidade de vencerem por seu esforço nos estudos. Isso ajuda a desenvolver uma ligação entre quantidade e qualidade, dos estudos com a vitória. 
Isso mostra que não apenas os benefícios cognitivos advindos da prática do xadrez justificam sua inclusão nas escolas, mas sim outros pequenos "detalhes" que fazem toda a diferença e contribuem para elevá-lo do patamar de simples jogo ao patamar de ferramenta pedagógica.

Campitelli e Gobet (2007), ao fazer uma varredura sobre os estudos científicos sobre o xadrez, propõem um "experimento ideal", baseado nas lacunas apresentadas pelos estudos anteriores. Tal experimento fundamenta-se no fato de que as ciências educativas, a exemplo da psicologia e da medicina, desenvolveram uma variedade de técnicas para estabelecer se um determinado tratamento, atividade ou prática afeta positivamente algum comportamento. Espera-se que 0 grupo experimental, ou seja, o grupo que pratica xadrez, seja comparado a um grupo controle, e as possíveis diferenças sejam avaliadas mediante a aplicação de um pré e um pós-teste. Neles, deve ser utilizado um instrumento de avaliação que meça a variável desejada, que no caso da presente pesquisa é o raciocínio. Visando um estudo mais robusto, Campitelli e Gobet (2007) indicam a utilização de dois grupos controle. O primeiro receberia um tratamento alternativo, e o segundo não receberia nenhum tratamento. Isso excluiria a justificativa de que o incremento observado no grupo experimental fosse advindo apenas da participação em alguma atividade extra, seja ela qual for. Com isso, exclui-se essa possibilidade, sendo possível concluir que o efeito se deve a características presentes apenas no grupo de tratamento.

Na tabela 1 abaixo, Campitelli e Gobet (2007) buscam os principais estudos sobre o xadrez, comparando-os com o "experimento ideal".

Tabela 1 - Compilação de estudos enxadrísticos em comparação com o experimento ideal

\begin{tabular}{|c|c|c|c|c|c|c|c|}
\hline \multicolumn{2}{|c|}{$\begin{array}{c}\text { Designação } \\
\text { aleatória }\end{array}$} & $\begin{array}{l}\text { Pré - } \\
\text { teste }\end{array}$ & $\begin{array}{l}\text { Pós- } \\
\text { teste }\end{array}$ & $\begin{array}{l}\text { Grupo - } \\
\text { controle I } \\
\text { (placebo) }\end{array}$ & $\begin{array}{c}\text { Grupo - } \\
\text { controle II } \\
\text { (sem } \\
\text { tratamento) } \\
\end{array}$ & $\begin{array}{c}\text { Experimentador } \\
\text { diferente na } \\
\text { aplicação dos } \\
\text { testes } \\
\end{array}$ & $\begin{array}{l}\text { Participantes } \\
\text { desconheciam o } \\
\text { experimento }\end{array}$ \\
\hline Experimento ideal & $\sqrt{ }$ & $\sqrt{ }$ & $\sqrt{ }$ & $\sqrt{ }$ & $\sqrt{ }$ & $\sqrt{ }$ & $\sqrt{ }$ \\
\hline Christiaen (1976) & $\sqrt{ }$ & & $\sqrt{ }$ & & $\sqrt{ }$ & $\sqrt{ }$ & $\sqrt{ }$ \\
\hline Frank (1979) & $\sqrt{ }$ & $\sqrt{ }$ & $\sqrt{ }$ & & $\sqrt{ }$ & $\sqrt{ }$ & ? \\
\hline Liptrap (1998) & & $\sqrt{ }$ & $\sqrt{ }$ & & $\sqrt{ }$ & $\sqrt{ }$ & $\sqrt{ }$ \\
\hline Ferguson 1 (1983) & & $\sqrt{ }$ & $\sqrt{ }$ & & $\sqrt{ }$ & ? & ? \\
\hline Ferguson 2 (1988) & & $\sqrt{ }$ & $\sqrt{ }$ & & $\sqrt{ }$ & ? & ? \\
\hline Margulies & & $\sqrt{ }$ & $\sqrt{ }$ & & $\sqrt{ }$ & $\sqrt{ }$ & $\sqrt{ }$ \\
\hline Fried e Ginsburg & $\sqrt{ }$ & & $\sqrt{ }$ & $\sqrt{ }$ & $\sqrt{ }$ & $\sqrt{ }$ & ? \\
\hline
\end{tabular}

Fonte: CAMPITELLI; GOBET, 2007, p. 186. 
Com isso, podemos ver que nenhum estudo feito preenche todos os requisitos para ser considerado "perfeito". Apenas um dos estudos se aproximou razoavelmente do "experimento ideal", mas não utilizou um pré-teste e não se sabe se os participantes sabiam ou não que estavam fazendo parte de um experimento.

Tendo esse conceito de "experimento ideal" em mente, busquei preencher as lacunas apresentadas nas pesquisas anteriores, objetivando também incrementar e expandir suas possibilidades. Porém, seguir todas as recomendações e se encaixar em todos os pré-requisitos, de acordo com Campitelli e Gobet (2007), para executar um "experimento ideal”, não é tarefa fácil. Aliás, seguir tudo à risca é impossível. Os próprios autores reconhecem as dificuldades de conduzir um experimento com tais características. As dificuldades residem nas razões práticas, administrativas e éticas. No caso do presente estudo, o grande entrave são as questões éticas. Para aplicação dos testes e participação na pesquisa, é obrigatória a assinatura, pelos responsáveis das crianças que compõem o estudo, de um Termo de Consentimento Livre e Esclarecido, o qual deve conter toda a natureza do estudo, seu objetivo e procedimentos. Dessa forma, é impossível preencher o requisito de que os sujeitos não devem conhecer o propósito da pesquisa ou não saber que estão sendo parte dela. Além disso, é difícil ocultar dos sujeitos de que estão participando, sendo observados e avaliados, já que a presença de um pré-teste pode alertar os participantes de que estão fazendo parte de um experimento.

Portanto, o objetivo principal do presente estudo foi o de analisar o raciocínio de crianças, que praticaram xadrez por 10 semanas, por meio do Teste Não Verbal de Raciocínio e comparar seu desempenho com o de crianças que frequentaram o reforço escolar, a fim de verificar a existência de diferenças significativas entre o desempenho de ambos os grupos. Além disso, foi investigado se existem diferenças entre o desempenho de crianças do sexo masculino e crianças do sexo feminino no TNVRI, bem como a relação entre expertise enxadrística e desempenho no TNVRI. 


\section{EIXO TEÓRICO}

\subsection{O QUE É JOGO?}

O conceito de jogo deve permanecer distinto de todas as outras formas de pensamento através das quais exprimimos a estrutura da vida espiritual e social. Teremos, portanto, de limitar-nos a descrever suas principais características (HUIZINGA, 2012, p. 10).

Huizinga (2012), em seu clássico Homo Ludens, deixa claro como é complexo e perigoso encarcerar a definição de jogo em uma simples frase. $O$ ato de jogar supera a existência do homem, já que, segundo o mesmo Huizinga (2012, p. 3), "os animais não esperaram que os homens os iniciassem na atividade lúdica". Com isso, vemos a importância do jogar, como esse ato acompanha e influencia a história da humanidade, transpassando-a e tecendo-a, de forma coadjuvante, e, em alguns momentos, como protagonista. O que dizer da guerra, tão antiga, e tão semelhante a um jogo?

A importância do jogar é discutida em seus demais aspectos dentro das mais variadas áreas do conhecimento. Como função biológica, ainda não foi possível chegar a um consenso sobre tal definição. Uns definem suas origens como uma descarga da energia vital superabundante, busca pela satisfação e prazer ou simplesmente a necessidade de relaxamento. Outras vertentes afirmam ser uma preparação do jovem para tarefas sérias que mais tarde lhe serão exigidas na vida. Outras ainda afirmam que o jogar é um exercício de autocontrole indispensável ao indivíduo, uma vontade incontrolável de dominar ou competir, ou ainda da "realização do desejo" (HUIZINGA, 2012, p. 4).

Dentre as hipóteses e possíveis definições de jogo, um ponto se mostra comum: todas consideram o jogar como sendo ligado a alguma coisa que não seja ele mesmo, que no ato de jogar deve haver alguma espécie de finalidade biológica.

Desde já encontramos aqui um aspecto muito importante: mesmo em suas formas mais simples, ao nível animal, o jogo é mais do que um fenômeno fisiológico ou um reflexo psicológico. Ultrapassa os limites da atividade puramente física ou biológica. É uma função significante, isto é, encerra um determinado sentido. No jogo existe alguma coisa "em jogo" que transcende as necessidades imediatas da vida e confere um sentido à ação. Todo jogo significa alguma coisa. Não se explica nada chamando "instinto" ao princípio ativo que constitui a essência do jogo; chamar-lhe "espírito" ou "vontade" seria dizer demasiado. Seja qual for a maneira como o considerem, 0 
simples fato de o jogo encerrar um sentido implica a presença de um elemento não material em sua própria essência (HUIZINGA, 2012, p. 3).

Todas as respostas, porém, não passam de soluções parciais do problema. Brougère (1998) buscou distanciar-se do desafio advindo da definição de jogo. Entretanto, embrenha-se em outra tarefa igualmente complexa: "determinar as significações e usos do termo; o contexto semântico de seu emprego" (BROUGĖRE, 1998, p. 13). Ao iniciar tal jornada, o autor já deixa claro que não podemos agir como se tivéssemos em mãos um termo claro e transparente, de um conceito construído, fechado e definido. $O$ conceito de jogar é uma noção aberta, polissêmica e, às vezes, ambígua. Parece-nos simples definir uma atividade como sendo jogar ou não, mas o que tem em comum entre duas pessoas jogando xadrez e um gato empurrando uma bola? Entre dois peões pretos e brancos em um tabuleiro e uma criança embalando uma boneca? Diante de tais situações, fica visível a dificuldade em obter de tais atividades pontos em comum.

Interessante como Brougère (1998, p. 14) nos apresenta a "absurda" hipótese: "e se o único ponto em comum fosse a utilização do mesmo termo?". Com esse choque em nossa concepção, o autor evidencia que a questão principal é saber o porquê de atividades tão diferentes terem sido designadas pelo mesmo termo, tanto em nossa língua como em muitas outras. A ciência denomina jogar como "atividade lúdica", mas não se sabe de onde esse termo vem, seja pela sensação da pessoa que joga, ou pela observação externa de alguém jogando.

Muitos confundem, ou mesmo consideram igual, a definição de jogo e de brincadeira. Existe diferença? Xadrez é um jogo ou é uma brincadeira? Complexa é a relação entre jogo e brinquedo. Brougère (1998) afirmou que, ao se deparar com um material lúdico, certos objetos são encaixados na categoria jogo; outros, na categoria brinquedo. O brinquedo remete a uma indeterminação quanto ao uso, ou seja, uma liberdade para se escolher como se deseja brincar, uma "ausência de relação direta com um sistema de regras quanto ao uso" (BROUGÈRE, 1998, p. 153). Por outro lado, Vigotski (2007) afirmou que é impossível desassociar a brincadeira da regra. E vai além, afirmando que não existe brinquedo sem regras. regras previamente formuladas e que mudam durante o jogo, mas as que têm sua origem na própria situação imaginária. Portanto, a noção de que uma criança pode se comportar em uma situação imaginária sem regras é simplesmente incorreta (VIGOTSKI, 2007, p. 111, 112). 
Brougère (1998, p. 15), entretanto, afirmou que "o brinquedo não é a materialização de um jogo, mas uma imagem que evoca um aspecto da realidade e que o jogador pode manipular conforme sua vontade". Já um material lúdico destinado ao jogo implica, de maneira explícita, seu uso de acordo com uma regra.

Para apimentar a discussão, coloco uma situação hipotética à mesa: imaginem duas peças de xadrez, o rei e a dama. Ambas são brinquedos ou parte constituinte de um jogo? Se apresentarmos essas peças a uma criança que não conhece o que é xadrez, o que fará ela? E a uma que conhece plenamente as regras do jogo? Qual será a atitude de cada criança diante de tais peças? O rei e a dama serão um simples brinquedo ou serão vistos como parte constituinte de um jogo?

Creio que não importa para nós, diante deste estudo, a definição de jogo e de brincadeira, bem como a diferença entre elas. O que importa, em todos anos de experiência que tenho, é que o xadrez seja visto como diversão, e se distancie cada vez mais de uma atividade cansativa e desgastante. Ensinar uma criança a jogar xadrez acaba sendo o menor dos desafios. O grande desafio é moldar e ajustar a prática do jogo para propiciar momentos de prazer, diversão e alegria. A partir do momento em que a criança encara o jogo como uma brincadeira e passa a ter a diversão como motor principal para o jogo, aprender a jogar se torna uma consequência que acontece sem que a criança perceba.

Macedo e Passos (2005, p. 14) também se aventuram na difícil tarefa de definir e diferenciar brincadeira de jogo e ilustra com maestria o ponto ao qual quero chegar, que é de não menosprezar nem o jogo nem a brincadeira, mas colocá-los em patamares de igual importância. Os autores nos trazem uma relação de sequência entre brincadeira e jogo, afirmando que "O jogo é uma brincadeira que evoluiu".

O jogar é um dos sucedâneos mais importantes do brincar. O jogar é o brincar em um contexto de regras e com um objetivo predefinido. Jogar certo, segundo certas regras e objetivos, diferencia-se de jogar bem, ou seja, da qualidade do efeito das decisões ou dos riscos. O brincar é um jogar com ideias, sentimentos, pessoas, situações e objetos em que as regulações e os objetivos estão necessariamente predeterminados. No jogo, ganha-se ou perde-se. Nas brincadeiras, diverte-se, passa-se um tempo, faz-se de conta. No jogo, as delimitações (tabuleiro, peças, objetivos, regras, alternância entre jogadores, tempo, etc.) são condições fundamentais para sua realização. Nas brincadeiras, tais condições não são necessárias. O jogar é uma brincadeira organizada, convencional, com papéis e posições demarcadas. 
Isso responde, de certa forma, à pergunta por mim feita anteriormente. Um rei e uma dama são brinquedos ou parte constituinte de um jogo? A resposta mais coerente para tal pergunta seria que ambas estão corretas. Não é o objeto que define se é um jogo ou uma brincadeira, mas sim o objetivo da atividade a ser desempenhada com ele.

\title{
2.2 O QUE É XADREZ?
}

O xadrez é um jogo por sua forma, uma arte por seu conteúdo e uma ciência pela dificuldade de ganhar maestria nele. Xadrez pode transmitir tanta felicidade como um bom livro ou uma boa obra musical pode. No entanto, é necessário aprender a jogar bem e só depois experimentar um verdadeiro deleite (PETROSIAN, [1981?]; tradução nossa).

Como José Raúl Capablanca (2002) definiu, xadrez é algo mais que um simples jogo. Há milênios presente na história, peregrino por nações há muito extintas, o xadrez resiste, persiste e se firma como um jogo complexo e determinante para o desenvolvimento do ser humano, e até mesmo de sua própria história. De tão antigo, pouco se sabe e muito se cogita sobre sua criação. A história que é contada mais vezes e, portanto, considerada a mais próxima da realidade é, ironicamente, uma lenda.

\begin{abstract}
Atribui-se a invenção do jogo a Sissa, um brâmane na corte do rajá indiano Balhait. O rei havia pedido ao sábio que criasse um jogo capaz de demonstrar o valor de qualidades como a prudência, a diligência, a visão e o conhecimento, opondo-se nesse sentido ao ensinamento fatalista do nard (nosso gamão), no qual o resultado é decidido pela sorte. [...] Sissa apresentou ao rei um tabuleiro de xadrez, com peças não muito diferentes das que usamos hoje. Essas peças representavam os quatro elementos do exército indiano: carros, cavalos, elefantes e soldados a pé - comandados por um rei e seu vizir. Sissa explicou que escolhera a guerra como modelo para o jogo porque a guerra era a escola mais eficiente para se aprender 0 valor da decisão, do vigor, da persistência, da ponderação e da coragem. [...] O nome do jogo, tal como se praticava na índia, era chaturanga, o que significava "exército formado de quatro membros" (LASKER, 1999, p. 29; 30; 31).
\end{abstract}

A lenda continua, contando sobre a sabedoria de Sissa ao pedir uma recompensa ao Brâmane. No entanto, o que nos interessa é apenas saber que o chaturanga, antecessor do xadrez, foi criado com o objetivo de se opor a jogos "fatalistas", ou seja, àqueles nos quais a sorte é o que define o resultado. Mesmo 
que, inicialmente, o jogo de xadrez ainda continha elementos decididos pela sorte, ao longo dos anos alterações foram feitas e o fator sorte desapareceu completamente do tabuleiro. Essas modificações também se estenderam ao tabuleiro e às peças. Ao peregrinar, principalmente para oeste até a Pérsia e Arábia, o xadrez chega até a Europa. Mudanças vão ocorrendo ao longo dos anos. O número de jogadores caiu de quatro para dois, as peças sofreram alterações de forma e nome, algumas movimentações e capturas também mudaram.

É particularmente interessante ver como cada modificação, nos nomes e nas formas das peças, foram feitas, em cada língua, pelo simples "mal-entendido" com os termos mais antigos. De acordo com Edward Lasker (1999), o "rei" não sofreu alteração em nenhuma língua, sendo todos apenas traduções da palavra Shah, assim como o "peão", traduzido da palavra Baidaq. As demais peças sofrem alterações em seus nomes devido à má interpretação, confusão ou simples "licença poética". O árabe Faras, que representa o "cavalo", foi mantido em várias línguas e, em outras, posteriormente, transformou-se em cavaleiro ou homem a cavalo - o Knight, Cavalier, Ritter, Springer etc. Por desconhecerem o significado da palavra Rukh, a palavra era mantida, respeitando as características de cada língua - Roque, Rocco, Rook etc. Após alguns indianos construírem a peça "torre" na forma de um elefante carregando uma torre, o vocábulo alemão Turm se difundiu, resultando em Tour, Torre e Castle em algumas línguas. O termo árabe Firz, que representava o vizir, o conselheiro, sobreviveu algum tempo na Espanha sob a alcunha de Ferz ou Alfferza, que se transformou em Firge ou Vierge, em francês antigo. Todavia, no final, todos se renderam ao termo que representa a "dama", tal como Dam ou Reine Konigin, em alemão. Pela mesma "falta de tradução", o termo Al-fil, vocábulo árabe que significa elefante, é como se chama o "bispo" na Espanha nos dias atuais, assim como na Itália chama-se Alfiere. Cada língua traduziu o termo Al-fil da forma como desejava, sendo Velho (Der Alte), em alemão, Bishop e Bispo, em inglês e português, respectivamente. Já na França, novamente, a corrupção do vocábulo árabe fil transformou-se em Fou, o tolo ou bobo da corte. Tal equívoco também se origina do formato da peça, com uma fenda no alto, que representava inicialmente as presas do elefante, mas que foram interpretadas erroneamente como a mitra de bispo ou do gorro de bobo da corte (LASKER, 1999).

Seguindo as regras, ainda intactas, referentes ao jogo, o exército de cada jogador de xadrez ainda luta e sucumbe no momento em que o rei não puder 
escapar da captura. Esse é o famoso xeque-mate. O campo de batalha é um tabuleiro de 8 por 8 casas, coloridas alternadamente entre casas claras e escuras, que geralmente chamamos de "brancas" e "negras". Cada um dispõe de uma dama e um rei, dois bispos, dois cavalos, duas torres e oito peões, dispostos da seguinte forma, como podemos ver na imagem a seguir:

Figura 2 - Tabuleiro de xadrez

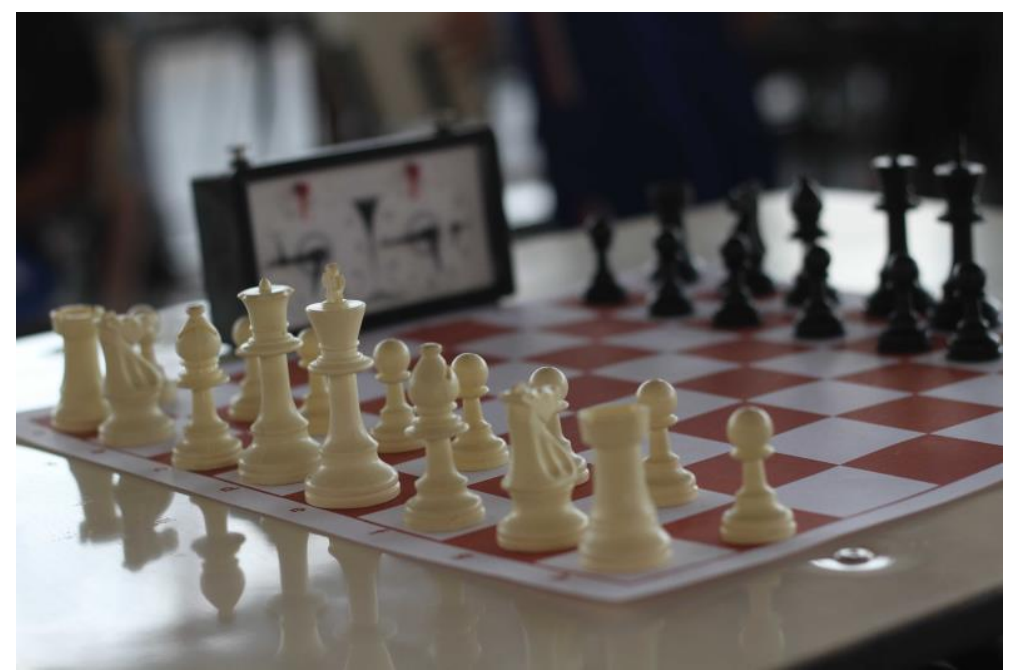

Fonte: Sá; Rezende Júnior; Melo, 2013, p. 276.

Os jogadores devem mover alternadamente uma de suas peças, sendo que as brancas fazem o primeiro movimento. Quando uma peça se movimenta e ocupa a casa de uma adversária, acontece o que chamamos de "captura", devendo ser retirada a peça do oponente e colocada a do jogador que a capturou em seu lugar. Cada peça deve mover-se de uma forma característica, sendo que cada uma movimenta-se de forma diferente.

O rei, ao contrário de sua aparente imponência, é fraco se comparado a outras peças. Movimenta-se apenas uma casa, em qualquer direção. Já a dama, ao contrário da sua imagem de subordinação perante o rei, é a peça mais forte do jogo, movimentando-se em qualquer direção (horizontal, vertical e diagonal), quantas casas desejar. A torre move-se na vertical e horizontal, também por quantas casas desejar. O bispo, ao contrário da torre, apenas na diagonal e, semelhante à torre, movimenta-se por quantas casas forem possível. O peão e o cavalo têm movimentações peculiares, se comparados às outras peças. $\mathrm{O}$ peão movimenta-se uma casa para a frente, mas captura apenas na diagonal, também na distância de uma casa. Porém, ao peão foi concedido o poder de andar duas casas, caso seja 
seu primeiro lance no jogo, além de ser "promovido" à outra peça, caso alcance a borda do tabuleiro. Sobre o cavalo, diversas orientações podem ser dadas a fim de entender sua movimentação. De acordo com Edward Lasker (1999, p. 283), “O cavalo pode mover-se em qualquer direção para a segunda casa de cor diferente daquela onde se encontra". Outra explicação, comumente utilizada em ambientes escolares, é a de que o cavalo anda em "L", ou seja, duas casas para frente e uma para o lado. Além disso, ao cavalo foi concedido o poder de saltar sobre qualquer peça.

Como foi dito anteriormente, o jogo acaba quando o rei não puder escapar de uma iminente captura. Ao lance que ataca o rei, ameaçando-o de captura, damos o nome de "xeque". Ao se encontrar em tal situação, o adversário deve fazer um lance capaz de tirar o rei do xeque. Caso não aconteça, considera-se que o rei está em situação do tão conhecido "xeque-mate", que se origina do termo persa shāh māt, que literalmente significa "o rei está derrotado" ou o "rei está emboscado". O jogo de xadrez é tido como uma "obra-prima" devido à sua clareza e facilidade quantos às regras e às diversas possibilidades de movimento. Para muitos, o que faz o xadrez tão apaixonante é a ausência do fator sorte e a grande evidência do fator planejamento. Muitos jogos famosos (cartas, por exemplo) envolvem a sorte como fator determinante, sendo a habilidade do jogador posta em segundo plano. Já no xadrez, acontece o contrário. O fator sorte foi, ao longo dos anos, sendo cada dia mais distanciado, deixando, assim, espaço para o planejamento, avaliação e execução de estratégias e táticas.

Edward Lasker (1999, p. 11-12) demonstra com maestria o porquê de o xadrez fascinar a quem o pratica:

Certa vez perguntei a diversas pessoas eminentes por que eram
apaixonadas pelo xadrez. Dois conhecidos líderes comerciais deram-me
respostas quase idênticas. Disseram que era porque o xadrez limitava o
elemento de sorte e acentuava a importância do planejamento. Um músico
escreveu que para ele o xadrez era como a própria vida: ensinava-o a
coordenar a razão com o instinto. Um matemático apreciava o elemento
estético do jogo; encontrava numa série de movimentos sutis a mesma
emoção que um belo teorema.

Isso mostra que xadrez vicia por diversos motivos, que variam de acordo com o perfil de quem o joga. Uma criança, por exemplo, teria motivos completamente diferentes desses apresentados, mas que nem por isso perdem seu valor. 


\title{
2.3 POR QUE O XADREZ NAS ESCOLAS?
}

\begin{abstract}
Educação em xadrez tem que ser uma educação de pensamento e julgamento independente. $O$ xadrez não deve ser memorizado, simplesmente porque não é importante o suficiente [...] A memória é muito valiosa para ser entulhada com frivolidades (LASKER, 2008, p. 337, tradução nossa).
\end{abstract}

Por muitos visto como passatempo, frivolidade, relaxamento e "distensão" da vida cotidiana dura e cansativa, o xadrez traz à comunidade científica o desafio de investigar se tal "frivolidade" deve ser inserida nas escolas. Como o próprio Capablanca (2002, p. 11) salientou, "O xadrez serve, como poucas coisas neste mundo, para distrair e esquecer momentaneamente as preocupações da vida diária". Por outro lado, no mesmo livro, o autor afirmou que, "Começando aos dez anos, todos os escolares deviam receber regularmente lições dessa matéria, variando a duração das classes, segundo a idade e a capacidade dos alunos" (CAPABLANCA, 2002, p. 11). Analisando essas afirmações, vemos uma contradição, quase um paradoxo. De acordo com o autor, o xadrez deve ser inserido nas escolas. Porém, a justificativa para essa inserção é a capacidade de "relaxar" a mente dos alunos perante as dificultosas e complexas disciplinas e conhecimento adquiridos nas aulas tradicionais? Ou o xadrez se justifica pela enorme e mal explorada capacidade de aprimorar e desenvolver as habilidades cognitivas tão requeridas em sala de aula (e fora dela), tais como memória, raciocínio, criatividade?

\begin{abstract}
Além de sua importância no âmbito esportivo, aumenta, no contexto atual, o número de países que começam a adotar o ensino do xadrez como instrumento didático-pedagógico, e cada vez mais pesquisadores, pais e professores em todo o mundo descobrem os benefícios educacionais diretos e indiretos decorrentes de sua prática. Dessa forma, é oportuno, principalmente no Brasil, verificar quais são esses benefícios e como devem ser trabalhados a fim de atingir uma maior parcela da população (FILGUTH, 2007, p. 7).
\end{abstract}

Dauvergne (2007) afirmou que o xadrez é uma ferramenta pedagógica especialmente efetiva, pois auxilia, em vários níveis de desenvolvimento e dificuldade, a desenvolver habilidades cognitivas de suma importância para a vida social e acadêmica das crianças. Cada característica do xadrez auxilia no desenvolvimento de alguma dessas habilidades. Todo jogador deve possuir um plano se deseja vencer um jogo. Isso desenvolve e aprimora a capacidade de planejar e de lidar com as consequências de suas decisões. A criança, à medida que 
joga, percebe a necessidade de se concentrar no jogo, de controlar suas emoções, impulsos e vontades, e a pensar (e pensar bem) antes de agir.

Porém, a primeira questão que sempre me vem à mente, e, no caso, apresentada também por Campitelli e Gobet (2005, p. 3), é a seguinte: "Pode um conjunto de habilidades adquiridas em um domínio específico (no nosso caso, o xadrez) ser generalizado a outros domínios (por exemplo, matemática, leitura) ou à habilidades gerais (por exemplo, o raciocínio, a memória)?".

Vigotski (2007) e também Gobet, De Voogt e Retschitzki (2004) utilizaram como base os estudos de Thorndike e Woodworth (1901) para dissertar sobre essa questão. Nesse estudo, verificou-se que teóricos em psicologia e educação, e também professores, acreditavam (e agiam) com base na teoria de que a mente é um conjunto de capacidades e que a melhora em qualquer capacidade específica resulta numa melhora geral de todas as outras. "Portanto, se alguém aprende a fazer bem uma única coisa, também será capaz de fazer bem outras coisas sem nenhuma relação, como resultado de alguma conexão secreta" (VIGOTSKI, 2007, p. 92).

O escritor Millôr Fernandes se contrapôs, da forma bem-humorada com que habitualmente escreve seus textos, a tal afirmação de Vigotski. Em seu livro, ele diz que:

O xadrez tem tido sua prática incrementada apenas por motivos
competitivos lamentáveis. Pois é um jogo que não melhora o ser humano
para nenhuma outra prática, não o leva a melhor relacionamento humano,
não o torna melhor cidadão no sentido de uma lição de vida ou ação social,
nem mesmo à melhoria da linguagem rotineiramente falada. O xadrez
desenvolve apenas o tipo de inteligência que leva o indivíduo a jogar melhor
xadrez (FERNANDES, 2005, p. 55).

Vigotski (2007) se opôs ao seu próprio ponto de vista, apresentado inicialmente. Ele afirmou que um treino especial afeta o desenvolvimento global somente quando seus elementos, seus materiais e seus processos são similares nos vários campos específicos. Vigotski (2007) contribui afirmando que a melhora de uma habilidade só poderá afetar o desenvolvimento de outra se houver elementos comuns em ambas as atividades. Essa questão tem ocupado pesquisas na área da psicologia e da educação por séculos, e a conclusão a que chegamos foi a de que, para que haja uma transferência de habilidades, é necessário que sejam trabalhadas habilidades presentes em ambas as áreas as quais se deseja desenvolver. Como, 
por exemplo, habilidades adquiridas ao se aprender geometria têm maior propensão a serem transferidas para a aprendizagem de cálculos matemáticos mais avançados do que para a aprendizagem de história.

\begin{abstract}
A melhor aposta para se obter habilidades transferíveis parece ser ensinar justamente isso: habilidades transferíveis. É isso, habilidades genéricas e estratégias que ajudem a desenvolver o aprendizado, a solução de problemas ou o raciocínio (GOBET; DE VOOGT; RETSCHITZKI, 2004, p. 156, tradução nossa).
\end{abstract}

Nesse ponto é que o xadrez se distancia dos demais jogos e atividades. Particularmente naquele ensinado na escola, se feito de forma correta, a busca é justamente pelo ensino-aprendizagem de tais habilidades transferíveis, de métodos para resolução de problemas que sejam úteis em outras áreas de conhecimento. Memória, tomada de decisões, planejamento, criatividade e, principalmente, o raciocínio são exemplos de habilidades transferíveis desenvolvidas no xadrez. Emanuel Lasker (2008) foi um notório enxadrista alemão, detentor do título de grande mestre, além de ser matemático e filósofo. Em seu livro Lasker's Manual of Chess, de 1947, reserva um capítulo completo para falar sobre a educação pelo xadrez. Em uma das passagens mais interessantes e aplicáveis à nossa realidade atual, diz:

\begin{abstract}
Você não deve ter em mente nenhum nome, nem números, nem incidentes isolados, nem mesmo os resultados, mas apenas métodos [...] O método produz vários resultados. Alguns deles permanecerão em nossa memória, e, enquanto eles permanecem poucos, eles serão úteis para ilustrar e para manter viva as regras que ordenam mil resultados. Tais resultados úteis devem ser renovados de tempos em tempos tal como comida fresca deve ser fornecida a um organismo vivo para mantê-lo forte e saudável (LASKER, 2008, p. 337-338, tradução nossa).
\end{abstract}

Se analisarmos a instrução pelo xadrez do ponto de vista do fornecimento de fórmulas e resultados, ele em nada pode auxiliar alguém em qualquer outra atividade. Mas, se analisarmos do ângulo correto, vemos que o xadrez não busca ensinar números, nomes e "decorebas", mas sim métodos. Os métodos utilizados no xadrez para obtenção de resultados é que são o grande trunfo de tal jogo. Como afirmo anteriormente, se feito da forma correta, a instrução enxadrística proporciona a oportunidade da aprendizagem e, porque não, da criação de métodos para se resolver problemas e obter resultados desejados. 
O "x" da questão está no "se feito de forma correta". É importante deixar claro o papel de mediador que o professor deve ter no processo de desenvolvimento do aluno pelo xadrez. Mediação, em se falando de educação, refere-se ao posicionamento que o professor deve tomar na relação do aluno com o conhecimento. Ele é responsável por apresentar os conteúdos, potencializando, amplificando e enriquecendo as construções dos alunos, de forma intencional e significativa (CAMPOS; MACEDO, 2011).

O professor como mediador do conhecimento é responsável pelas atividades, não devendo apenas deixar os alunos jogando e esperar que a prática do xadrez, por si só, seja responsável pelo seu desenvolvimento. O professor deve organizar e propor atividades para que os alunos possam, primeiramente, aprimorar-se na prática do jogo, para depois conseguir trabalhar de forma mais autônoma, auxiliando, assim, o desenvolvimento de habilidades cognitivas, sociais e emocionais, descoberta e criação de métodos, ou seja, as habilidades transferíveis. Campos e Macedo (2011, p. 212) afirmaram que o professor também passa por momentos de aprendizagem ao se tornar mediador, e isso é de extrema importância para o sucesso da relação entre o aluno e o conhecimento, bem como o desenvolvimento de sua autonomia.

\footnotetext{
Experimentando e avaliando os resultados de suas orientações, os professores podem adquirir, aos poucos, mais segurança no emprego de intervenções que apelam para maior atividade e participação dos alunos e menor centralização de funções de sua parte, com mudanças significativas no modo de relação usualmente estabelecido em sala de aula.
}

O papel de mediador que o professor deve ter em sala de aula também se refere à motivação. Cabe ao professor criar atividades que sejam lúdicas a ponto de motivar os alunos para sua prática, sem necessidade de recompensá-los com notas e menções ou puni-los com broncas e advertências. Isso se faz necessário, pois a característica lúdica do xadrez, assim como de qualquer outro jogo, só é obtida quando ele é praticado de forma espontânea, ou seja, quando não é uma atividade imposta arbitrariamente (L. SILVA, 2010).

Em outro de seus estudos, Macedo e Passos (2005) abordaram esse ponto e apresentaram como é crucial o erro de se impor jogos e brincadeiras. Muitos professores forçam seus alunos a realizarem uma série de atividades, e, quando os alunos perguntam o porquê daquelas tarefas, os professores respondem da seguinte 
forma: "Fazendo isso você vai ficar mais inteligente, esperto e concentrado. Tudo que está sendo feito é para o seu bem. No futuro você vai me agradecer". Porém, Macedo (2005, p. 17) mostrou como demonstrar benefícios futuros não funciona quando o objetivo é motivar crianças a participarem de jogos e brincadeiras.

\footnotetext{
Em jogos e brincadeiras, as tarefas ou atividades não são meios para outros fins, são fins em si mesmos. Na perspectiva das crianças, não se joga ou brinca para ficar mais inteligente, para ser bem-sucedido quando adulto ou para aprender uma matéria escolar. Joga-se e brinca-se porque isso é divertido, desafiador, promove disputas com os colegas, possibilita estar juntos em um contexto que faz sentido, mesmo que as vezes frustrante e sofrido, por exemplo, quando se perde uma partida ou não se consegue uma certa realização.
}

Esse é um dos grandes erros nos programas de xadrez escolar, que buscam desenvolver habilidades nos alunos por meio da prática do jogo, que de forma imposta arbitrariamente auxilia apenas na rejeição dos alunos para com as aulas. Em nada adianta dizer que as crianças devem jogar xadrez, pois auxilia na memória, inteligência ou raciocínio. Crianças jogam e se motivam para jogar pelo simples fato do jogo ser divertido, desafiador e de promover disputas com os colegas, assim como Macedo (2005) citou anteriormente.

Seguindo o mesmo conceito, Garcia (2011) defendeu a inclusão do xadrez nas escolas, porém não como uma atividade fechada, impositiva e desprovida de aspectos lúdicos. Isso denota a urgência em se desvencilhar de métodos tradicionais de ensino, composto por aulas expositivas maçantes e uma grande quantidade de trabalhos, provas e testes. É necessário, cada vez mais, em qualquer disciplina, aulas mais lúdicas, interessantes e motivadoras, que despertem no aluno a vontade de aprender e buscar o conhecimento por conta própria, e não de sentar e esperar que o conhecimento seja imposto de forma verticalizada. Huizinga (2012, p. 9), ao falar sobre o jogo e a aprendizagem lúdica, afirmou que, "Antes de mais nada, o jogo é uma atividade voluntária. Sujeito a ordens, deixa de ser jogo, podendo no máximo ser uma imitação forçada". Leomagon Silva (2010) menciona, em seu estudo, que trabalhar o xadrez na escola, assim como qualquer outra disciplina do conhecimento, também apresentou dificuldades relacionadas a alunos que não gostaram do jogo e se mantiveram desinteressados pelas aulas. De nada adianta programas muito bem-elaborados que se propõem a inserir e se trabalhar o xadrez no ambiente escolar se os alunos não aderem à ideia e não participam. De Groot (1978) citou como parte dos "benefícios de baixo nível" a motivação. Estar motivado 
para a prática do xadrez é o primeiro passo para se conseguir qualquer resultado no ambiente escolar, tornando, assim, a motivação como um ponto crucial nos programas educacionais. Dessa forma, como afirmou Garcia (2011), o processo de ensino-aprendizagem deve ser repensado, de forma a se buscar um contexto educativo que seja qualitativo, participativo, dialógico e interativo, pois a melhor forma de aprender é quando se ensina com alegria, diálogo, hipertextualidade e interdisciplinaridade em sala de aula.

Um programa educacional, seja de xadrez ou de qualquer outra disciplina, deve levar a motivação como ponto-chave para seu sucesso. Deve-se estimular nos alunos a batalha contra a "preguiça mental". Esse termo é utilizado por Dewey (1959) para exemplificar atitudes que levam a uma resposta desprovida de reflexão profunda, dada a esmo, sem utilização do raciocínio. Ou seja, que em nada contribuem para o desenvolvimento de habilidades cognitivas que tanto almejamos. Segundo ele, é necessário desprender esforço a fim de se chegar a uma resposta, uma solução. Pois, do contrário, o resultado é apenas "[...] uma ação puramente apetitiva, cega e impulsiva [...]." (DEWEY, 1959, p. 26). E é justamente esse esforço que transforma a ação impulsiva em uma ação inteligente. "Pensar... é uma capacidade que nos emancipa da ação unicamente impulsiva e rotineira" (DEWEY, 1959, p. 26).

A necessidade de se empreender esforço, e a justificativa mais comum para não o fazê-lo, é melhor exemplificada no seguinte trecho:

É possível, entretanto, ainda não pensarmos reflexivamente, mesmo quando haja um estado de perplexidade e uma experiência prévia de que emerjam sugestões. Pois pode acontecer que não exerçamos suficiente crítica das ideias que nos ocorrem; que nos precipitemos para uma conclusão, sem pesar os argumentos em que se baseia; que renunciemos à busca, à investigação, ou a abreviemos indevidamente; que adotemos a primeira "resposta" ou solução que nos venha à cabeça, por preguiça mental, frouxidão ou por impaciência de chegar ao fim. Só estamos aptos a pensar reflexivamente quando nos dispomos a suportar a suspensão e a vencer a faina da pesquisa. Tanto a suspensão de juízo como a pesquisa intelectual a muitos desagrada: querem ver tudo acabado o mais cedo possível. Cultivam um hábito mental excessivamente positivo e dogmático ou receiam talvez que a condição de dúvida sofra a pecha de inferioridade mental. É nesse ponto, quando entram na pesquisa o exame e a verificação, que avulta a diferença entre pensamento reflexivo e pensamento mal orientado. Para pensar verdadeiramente bem, cumpre-nos estar dispostos a manter e prolongar esse estado de dúvida, que é o estímulo para uma investigação perfeita, na qual nenhuma ideia se aceite, nenhuma crença se afirme positivamente, sem que se thes tenham descoberto as razões justificativas (DEWEY, 1959, p. 25). 
Esse é um trecho que deveria ser considerado como rumo na prática de ensino de muitos professores, de xadrez ou de qualquer outra área do conhecimento. Estimular nos alunos essa sede, essa vontade, essa motivação em busca da "investigação perfeita", não tendo diante de si nenhuma crença, preconceito ou ideia imposta que se aceite sem o benefício da dúvida e do questionamento. Somente dessa forma podemos desenvolver as habilidades que os PCN recomendam no trecho em que diz que o aluno deve ter a capacidade de "Questionar a realidade formulando-se problemas e tratando de resolvê-los, utilizando para isso o pensamento lógico, a criatividade, a intuição, a capacidade de análise crítica, selecionando procedimentos e verificando sua adequação" (BRASIL, 1997, p. 69).

O xadrez emerge diante de outras estratégias e ferramentas pedagógicas justamente por ser um jogo capaz de despertar em cada aluno essa motivação para o pensar, que é inerente a ele. Em um jogo de xadrez, cada aluno consegue facilmente compreender que o seu desenvolvimento no jogo depende enormemente do quão dedicado ele é em raciocinar em cada lance. Jogar impulsivamente leva inevitavelmente à derrota. Existe até um termo próprio para lances feitos impulsivamente, sem a devida reflexão. São os chamados "Lances Anódinos", lances feitos sem objetivos definidos, ao esmo. A justificativa para a realização desses lances anódinos pode ser encontrada em um trecho da citação anterior de Dewey. O autor afirma que "tanto a suspensão de juízo como a pesquisa intelectual a muitos desagrada: querem ver tudo acabado o mais cedo possível" (DEWEY, 1959, p. 25). No xadrez, é comum ver alunos que, com preguiça de pensar, jogam qualquer peça. Quando questionados do porquê de realizar tal lance, eles respondem com um sonoro "Não sei". É praticamente o mesmo que dizer "Não sei, apenas dei um chute". É mais fácil "chutar" uma resposta em uma questão de múltipla escolha do que "suportar a suspensão e a vencer a faina da pesquisa" (DEWEY, 1959, p. 25).

Porém, o xadrez mostra, na prática, a cada aluno, que chutar pode não ser a melhor alternativa. Pensar, de forma autônoma, na saída para cada situaçãoproblema com a qual se defronta traz resultados mais positivos e se aprimora a cada vez que é utilizado. E o mais interessante é que essa "saída" deve ser obtida apenas pelo próprio aluno e pelo seu próprio raciocínio. Por ser um jogo individual, as decisões não sofrem influência direta de treinadores, companheiros ou até mesmo 
da torcida, no caso do xadrez. Mesmo que comandos ou ordens tenham sido dadas antes do jogo ou durante o treinamento, são as decisões durante o jogo que definem a vitória ou derrota. E, justamente pela característica peculiar do xadrez em possuir uma árvore inimaginável de possibilidades de lance, torna-se quase impossível orientar um jogador sobre a sequência correta de lances a se executar.

Duas passagens citadas no parágrafo anterior merecem uma atenção especial ao se justificar a implantação do xadrez nas escolas: "Jogo individual" e "Pensar, de forma autônoma". Ambas parecem simples, mas estão carregadas de significado e são primordiais na compreensão do porquê implantá-lo nas escolas.

\subsubsection{O que é competição?}

Em relação ao termo "jogo individual", ele muito nos remete à competição e individualismo exacerbado. Primeiramente, competição se refere ao ato ou processo de se conseguir ou ganhar algo, que alguém também está tentando conseguir. Com isso, vemos que a competição envolve dois indivíduos que buscam o mesmo objetivo, sendo que apenas um deles o pode conseguir. A palavra "competição" está arraigada na sociedade como algo ruim, cheia de conotações negativas e vista como algo a ser contundentemente evitado e combatido. Quando falamos de jogo, o fator competição é algo intrínseco, que deve ser visto com cautela, principalmente no ambiente escolar. Por mais que jogos cooperativos estejam figurando em larga escala os planejamentos dos professores, principalmente de educação física, os jogos competitivos ainda são parte integrante e protagonista das quadras, praças, ruas e espaços dedicados a prática esportiva.

O xadrez é um esporte individual e competitivo. O objetivo é sobrepujar as estratégias e táticas do adversário a fim de executar o xeque-mate antes que ele o faça, seguindo as regras previamente estabelecidas mundialmente. Essa busca por "derrotar o inimigo" é o que causa receio em muito educadores ao lidar ou propor o jogo de xadrez. Muitas encaram a competição como algo maléfico, evitando-a ou mascarando-a, a fim de tornar o jogo mais "saudável". De acordo com Kamii e DeVries (2009, p. 274), existem quatro razões pelas quais professores são contra a competição, e elas são:

1) As crianças já são competitivas demais, e não devemos colocá-las em situações que as tornem ainda mais competitivas; 
2) Já existe bastante competitividade em nossa sociedade, e as crianças logo estarão expostas a ela, no próprio ensino fundamental;

3) Os jogos incomodam as crianças que perdem;

4) As crianças devem competir consigo mesmas, e não umas com as outras.

As autoras argumentam e derrubam, uma a uma, cada razão em que professores se baseiam para evitar a competição. Porém, um trecho resume perfeitamente o grande problema da competição:

Existe uma diferença entre comparar desempenhos e competir. A primeira é
uma condição necessária, mas não suficiente para a segunda. A
competição é uma comparação mais alguma coisa - tentar exceder ou
superar os outros. A criança torna-se orgulhosa, agressiva e ofensiva.
Alguns adultos reforçam o sentimento de superioridade da criança, dando
prêmios, dizendo "Bravo!" e geralmente valorizando o fato de vencer. Os
adultos devem lidar com a competição mais naturalmente, para que a
criança também veja o fato de vencer como nada mais do que vencer. Sua
glorificação coroa o ganhador com um sentimento de superioridade, e o
perdedor com um sentimento de falha. Quando os adultos lidam de maneira
errada e destrutiva com a competição, ela se torna altamente indesejável
(KAMII; DEVRIES, 2009, p. 276).

O grande problema da competição é o modo errado com que ela é vista e conduzida. Ganhar nada mais é que ganhar, e ponto. $O$ ato de vencer não lhe dá um diploma de superioridade sobre os demais, apenas the garante que, naquele momento, sua estratégia foi melhor que a dos seus adversários. Em outra situação, em outro contexto, talvez ela não o seja e você venha a perder.

Podemos ver essa forma errada com que lidamos com a competição de forma clara em uma cena do filme Searching for Bobby Fischer (SEARCHING, 1993). O filme conta a história de um garoto de 7 anos chamado Josh Waitzkin, que acaba se mostrando como um prodígio no xadrez. A trama do filme gira em torno das dificuldades de sua família em saber como lidar com esse dom. Seu pai contrata um professor particular renomado, que busca tornar Josh no novo "Bobby Fischer" (Grande Mestre campeão mundial de xadrez em 1972), enquanto sua mãe o incentiva a se divertir jogando contra adversários no parque.

A cena que desejo usar como exemplo se passa em um campeonato de xadrez escolar, em que várias crianças estão reunidas, jogando. professor/organizador do campeonato direciona o seguinte discurso aos pais/mães e acompanhantes no torneio: 
Ok. Quero lembrá-los de que devem se comportar como adultos. Eu não quero nenhum problema. Vocês sabem exatamente o que eu estou falando. Se você quiser assistir ao jogo, faça-o por trás do jogador. Sem pigarros. Sem comentários. Sem contato visual. Ninguém se importa se você é culpado ou não. Se todos se comportarem, eu acho que todos nós vamos ter bons momentos. Eu não estou brincando (SEARCHING, 1993).

Após todo esse sermão, o torneio se inicia. Em poucos minutos, já é possível ver em outra cena dois pais brigando pelo resultado do jogo entre seus filhos. A cena é cortada para um dos organizadores conduzindo todos os pais para o vestiário, alegando que é necessário dar-Ihes um recado longe das crianças. Ao chegarem ao vestiário, todos os pais, mães e acompanhantes são trancados lá e ficam impedidos de acompanharem os jogos. A próxima cena mostra o salão de jogos apenas com crianças, e todos se entreolham e começam a aplaudir, aprovando a decisão da direção do torneio em retirar todos os pais do evento.

Esta cena deveras chocante expõe como alguns adultos, em certos momentos, tornam a competição algo pesaroso e estressante. Buscando afirmar a capacidade de seus filhos e filhas, acabam por cobrar e pressionar para que obtenham a vitória a qualquer custo. $E$ isso é o que torna a competição maléfica e destrutiva.

Em outra cena, a professora de Josh conversa com seu pai, Fred, sobre as viagens que ambos têm ido para jogar campeonatos de xadrez. Porém, ela aconselha Fred de que o garoto pode até ser bom nessa "coisa de xadrez", mas que ele não deve se envolver muito, pois considera o jogo como "cartas, ou poker". Ao ouvir isso, o pai de Josh se sente insultado e responde à professora com uma frase que exemplifica bem o que havia afirmado anteriormente sobre cobrar de seus filhos resultados os quais nunca foram capazes de obter.

Ele é melhor nisso do que eu jamais fui na minha vida. Ele é melhor nisso do que você jamais vai ser, em qualquer coisa. Meu filho tem um dom. Ele tem um dom, e quando você reconhecer isso, então talvez teremos alguma coisa para falar (SEARCHING, 1993).

E para finalizar esse desserviço que pais e mães cometem com seus filhos, cito uma frase do próprio Josh que, ao se ver derrotado em uma partida, começa a desanimar e desistir de jogar xadrez novamente. Quando seu treinador pergunta porque ele está perdendo mais do que o habitual, ele responde: "Talvez seja melhor não ser o melhor. Então você pode perder e tudo fica bem" (SEARCHING, 1993). 


\subsubsection{O que é autonomia?}

Em relação ao termo "autonomia", Kamii e DeVries (2009, p. 39) afirmaram que o termo, originalmente, significa "autogoverno", que é o oposto de "heteronomia", que significa "ser governado por outrem". Autonomia é a "capacidade de julgar o que é certo e o que é errado em um conjunto específico de circunstâncias, baseando-se em valores morais e sociais adquiridos por meio de experiências próprias" (KAMII; DEVRIES, 2009, p.39 apud SÁ; REZENDE JÚNIOR; MELO, 2013, p. 277).

Kamii e DeVries (2009) salientam que autonomia não é fazer o que bem se deseja, mas sim equilibrar os desejos internos com as necessidades externas que a sociedade nos impõe, chegando a uma decisão adequada a todos os envolvidos. Um ser autônomo não é governado por um sistema de recompensas e punições, mas sim de valores e convicções que o guiam de acordo com o conjunto específico de circunstâncias que permeiam a situação. "Todas as crianças, a princípio, são heterônomas: à medida que crescem, algumas se tornam autônomas" (KAMII; DEVRIES, 2009, p. 40). Tendo essa frase em mente, vemos o grande papel que temos, como professores, em desenvolver o pensamento autônomo de nossos alunos, todos os dias, incessantemente. E o xadrez, utilizado como ferramenta pedagógica, pode nos auxiliar nessa tarefa. Em um jogo, por maior que seja a equipe técnica por trás de cada jogador, diante do tabuleiro, quem decide a melhor decisão a ser tomada e a executa é o jogador. Não existe um técnico ditando os lances ou estratégias a serem seguidas, nem um livro que possa ser consultado indicando o melhor lance, tampouco uma torcida gritando seu nome e incentivando-o a prosseguir. O que existe é o silêncio unido ao estardalhaço das correntes de pensamento cruzando sua mente como uma chuva de meteoros. Apenas o jogador pode decidir o que é melhor para ele. Por mais que ele se lembre do que seu técnico disse antes do jogo e por mais que ele se lembre da estratégia que o livro mais recente lançado prega como a melhor, está em suas mãos a decisão sobre qual movimento executar. Nenhum adulto pode lhe dizer o que fazer; o poder é todo seu.

Isso vai ao encontro do que pregam Kamii e DeVries (2009, p. 39), ao dizerem que "Em relação aos adultos, é desejável que as crianças desenvolvam sua autonomia por meio de relações seguras nas quais o poder do adulto seja reduzido o máximo possível". A cena do campeonato de xadrez, do filme Searching for Bobby 
Fischer (SEARCHING, 1993), citado anteriormente, mostra como essa "redução do poder adulto" é importante para que as crianças possam cooperar voluntariamente e possam construir, modificar e extinguir regras para si mesmas. Pode soar estranha a junção entre "cooperar" e "xadrez", já que, por ser um jogo em que se busca a vitória sobre o adversário, o termo cooperar parece fora de contexto. Porém, apesar de o xadrez ser uma atividade considerada pelo senso comum como fria, mecânica e introspectiva, a atmosfera reinante nas salas de aula não corresponde a tal representação (SÁ; REZENDE JÚNIOR; MELO, 2013). O autor afirma que as manifestações calorosas entre os alunos são frequentes e corriqueiras. Nos é óbvio que a dimensão relacional, presente no processo de ensino e aprendizagem, é de extrema importância para o desenvolvimento holístico do ser humano. Porém, o que difere do senso comum é a contribuição do xadrez para a socialização. Graças à sua carga lúdica, o xadrez é, constituindo-se como um jogo de regras, no sentido piagetiano, capaz de contribuir com a socialização (SÁ; REZENDE JÚNIOR; MELO, 2013, p. 277).

Outro ponto que une os termos "xadrez", "socialização" e "autonomia" é o fato de que ninguém joga sozinho. $O$ jogo requer um adversário. $E$ essa relação é parte importante para qualquer pessoa que deseja desenvolver o jogo de xadrez ou até mesmo estudá-lo mais profundamente.

No aspecto de socialização, deve-se ter em mente que não se pratica o jogo
sozinho, e assim é necessário respeitar o silêncio e a sua vez de jogar. Ao
final da partida, o aluno aprende a analisar a partida em conjunto, o que foi
e o que deveria ter sido jogado (post-mortem). O aluno também aprende
que deve manter a cordialidade com todos os participantes, e que é
necessário cumprimentar o adversário no início e no final da partida (SILVA,
2010, p. 220).

Utilizando novamente o exemplo do filme Searching for Bobby Fischer (SEARCHING, 1993), um dos personagens, Vinnie, aconselha o jovem Josh sobre como lidar com o adversário durante o jogo: "Jogue. Nunca contra o tabuleiro, sempre contra o homem. Você tem que jogar contra o homem 'jogando' no tabuleiro. Jogue contra 'mim'. Eu sou seu oponente, você tem que me vencer. Não o tabuleiro, vença a mim". Isso mostra como a interação entre "adversários" durante o jogo é de suma importância. Essa relação contribui imensamente para o desenvolvimento do pensamento autônomo. Kamii e DeVries (2009, p. 42) afirmaram que, "Em relação aos colegas, é desejável que as crianças desenvolvam a capacidade de se 
descentrar e coordenar diferentes pontos de vista". Isso significa que cada um deve aprender a se colocar no lugar do outro. No xadrez, essa ação é constante, pois somente vendo pelos olhos do adversário é possível desvendar seus planos e impedi-los antes que seja tarde. Como será abordado de forma mais profunda adiante sobre raciocínio, no xadrez cada jogador está constantemente tentando "prever" as ações do outro, e se colocar em seu lugar é uma das estratégias mais utilizadas. Garry Kasparov, um dos melhores jogadores que já existiram, foi perguntado sobre quantos movimentos ele conseguia prever em uma partida. Em resposta, ele afirmou que, "Se a jogada é direta, dá pra prever 15 movimentos. Em geral de 4 a 5 movimentos. Minha melhor contagem foi em 1999 contra o búlgaro (Topalov), que se tornou campeão mundial, foi de 15 movimentos" (JÔ SOARES, 2013). É de consenso geral a importância de descentrar e coordenar diferentes pontos de vista no xadrez; essa habilidade faz grande diferença no resultado de uma partida. Nesse ponto é que vemos a presença da cooperação no xadrez. "Cooperar", de acordo com Kamii e DeVries (2009), significa coordenar diferentes pontos de vista, colocar-se no lugar do outro, ser capaz de ver algo a partir de um ponto de vista que difere do seu.

Ao contrário do que se pensa, o xadrez pode ser um jogo cooperativo. Veloso-Silva e Sá (2012) afirmaram, em seu estudo, que existe uma capacidade do jogo de xadrez em promover o desenvolvimento cooperativo, apesar de ser uma atividade concebida como individual. Durante o jogo, é necessário conviver harmonicamente tanto em situações de liderança como de liderados, em face do respeito e da cordialidade presentes nas suas regras, que deve ser seguido em todos os jogos, sendo passível de severa punição o seu não cumprimento.

Kamii e DeVries (2009) utilizaram a concepção piagetiana para afirmar que a cooperação com outros indivíduos permite o desenvolvimento da moralidade e da autonomia. Além disso, afirmaram que é melhor que as crianças desenvolvam sua autonomia por meio de relacionamentos nos quais o poder do adulto seja reduzido o máximo possível. O xadrez tem papel importante nesse ponto, já que proporciona à criança se relacionar com as demais sem a necessidade da presença constante de um adulto para mediar a atividade. Enquanto o poder do adulto predominar, as crianças não estarão livres para se relacionar, resolver seus conflitos, cooperar ou para construir regras para si mesmas (KAMII; DEVRIES, 2009). 
Para exemplificar como o xadrez pode proporcionar situações de interação e construção cooperativa de conceitos e aquisição das regras, cito um impasse que relata bem situações corriqueiras nas aulas de xadrez do grupo experimental do presente estudo. Duas crianças discutem se uma peça pode ou não mover-se em diagonal. Uma afirma que sim, outra que não, e ambas não desistem diante dos argumentos do adversário. Diante do impasse, ambas passam a observar os jogos ao lado, buscando provas para corroborar sua tese sobre a movimentação da peça. Em certos momentos, ignorando o aspecto austero que muitos atribuem ao jogo de xadrez, interrompem o jogo ao lado para perguntar como a peça se move. $\mathrm{E}$ recebem como resposta, de ambos os jogadores, que sim, o Bispo move-se na diagonal. Após obter a comprovação que desejavam, o lance é executado da forma como os colegas ao lado confirmaram. É possível perceber que todo esse processo se deu sem participação de um adulto, não pelo fato de as crianças se recusarem a precisar de um, mas sim pelo simples fato de que não foi necessário chamar o professor responsável que estivesse próximo. A autonomia, como foi defendida por Kamii e DeVries (2009), desenvolve-se, principalmente, em situações como essa, em que o poder do adulto é reduzido ao máximo. Delgado e Muller (2005) exaltaram a importância desses momentos de interação e da ausência da influência do adulto, pois eles contribuem para o desenvolvimento da socialização, não de forma verticalizada como muitos creem, mas sim de forma colaborativa e interativa.

[...] as crianças aprendem com as outras crianças, nos espaços de partilha comuns. Essa partilha de tempos, ações, representações e emoções é necessária para um entendimento mais perfeito do mundo e faz parte do processo de crescimento (SARMENTO, 2004, p. 23-25 apud DELGADO; MULLER, 2005, p. 174).

A socialização, termo comumente citado em objetivos de atividades na escola, é tido como um destino a se alcançar por meio de ações planejadas pelo professor, com a presença dele. Porém, é ignorado o fato de que as crianças não "absorvem passivamente as realidades com as quais entram em contato. Não se trata de adaptação ou interiorização das regras, hábitos e valores do mundo adulto; elas atribuem significados ao mundo que as rodeia" (DELGADO; MULLER, 2005, p. 163).

Não devemos esperar que a socialização seja algo apenas internalizado pela criança, cabendo a ela adaptar-se o mais rápido possível. Muller (2008, p. 139) 
também contribuiu para elucidar como funciona o processo de socialização. A autora afirmou que:

\begin{abstract}
É possível sintetizar que a socialização é um processo relacional envolvendo simultaneamente a internalização e a mudança da sociedade por seus membros. Internalizar significa o aprendizado e a conformação de normas que transformam as pessoas em membros de suas sociedades. Por outro lado, a construção da identidade engloba não apenas a habilidade de se adaptar ao ambiente, mas também de agir e transformá-lo. É o resultado de um jogo de papéis e da síntese de diferentes significações vividas; não haveria uma identidade, porém processos identidários, que são dinâmicos, múltiplos e em constante transformação.
\end{abstract}

Ou seja, isso mostra que a socialização envolve um processo de mão dupla entre "moldar" e "ser moldado". Além de internalizar as regras e práticas aceitas pela sociedade, cabe ao indivíduo avaliar, aperfeiçoar e modificar aquelas com as quais não concorda ou em que visualiza uma possível melhora. O xadrez proporciona espaço para que essa liberdade criativa possa ser estimulada. O jogador, além de internalizar regras mundialmente definidas e ser instruído a seguir estratégias básicas arraigadas nos livros que abordam a prática do jogo, tem total liberdade para criar novos caminhos, trilhar novos rumos pelo tabuleiro e descobrir estratégias mais vantajosas do que aquelas que eram tidas como "dogmas" por enxadristas de gerações anteriores. Um exemplo prático e extremamente atual é do GM Magnus Carlsen, um jovem norueguês que, com apenas 13 anos, conseguiu ganhar do excampeão mundial Anatoly Karpov, detentor de título por 10 anos seguidos (1975 a 1985) e que ostentava mais de 40 anos de experiência no jogo de xadrez. Não satisfeito, Magnus também conseguiu empatar com Garry Kasparov, considerado por muitos o mais brilhante jogador de xadrez de todos os tempos, campeão mundial por 15 anos consecutivos (1985 a 2000). Tais façanhas surpreenderam a todos, atônitos com a habilidade do garoto e com suas jogadas surpreendentes. Justo quando todos estavam crentes de que o xadrez havia sido "resolvido", um garoto chega e muda tudo o que se achava que era correto, executando lances em que ninguém nunca havia pensado antes.

Mesmo que pareçam situações e conceitos diferentes, a socialização, muitas vezes idealizada de uma forma pelos "Kasparov's da pedagogia", é modificada e reinventada por jovens Carlsen pelo mundo, de forma tão inteligente e magnífica como a desempenhada pelo precoce gênio dos tabuleiros. 
Nesse sentido, Muller (2008, p. 139) indicou o quanto ainda precisamos avançar no entendimento da socialização, bem como no entendimento da infância como um todo. De acordo com a autora, podemos, e devemos, aprender com as crianças, dando voz a elas, ouvindo seus desejos e satisfazendo seus anseios, de forma simples, clara e direta.

Ainda que a escola ainda trabalhe com uma ideia vertical de socialização, as crianças mostram que esse processo é muito mais complexo. Mais do que o entendimento da sua condição social de aluno na escola, as crianças buscam diferentes caminhos para interagir com pares e transformar esse espaço-lugar planejado para elas pelos adultos.

\subsection{O QUE É RACIOCÍNIO?}

O único ponto que mereceu referência foi o curioso raciocínio analítico dos efeitos para as causas, por meio do qual consegui desvendar o problema. Sherlock Holmes (DOYLE, 2002, p. 7).

Não existiu, em toda a literatura, um personagem que usasse com maior maestria a capacidade de raciocínio do que Sherlock Holmes, criado por Sir Arthur Conan Doyle. Como vimos na introdução, raciocínio é a capacidade de se chegar a conclusões utilizando-se de princípios e provas (STERNBERG, 2010). O mesmo autor afirmou que o raciocínio é geralmente classificado em dois tipos diferentes: o raciocínio dedutivo e o raciocínio indutivo.

O raciocínio dedutivo é "o processo de raciocinar com base em uma ou mais afirmações gerais relativas ao que se conhece para obter uma conclusão logicamente correta" (STERNBERG, 2010, p. 446). Esse raciocínio é a "praia" de Sherlock Holmes. Baseado em fatos, características e detalhes "triviais" encontrados na cena de um crime, ele conseguia deduzir, com uma precisão de detalhes absurda, o autor do crime, as armas usadas e até mesmo os motivos que o levaram a fazer isso. Um dos tipos de raciocínio dedutivo, que Sherlock emprega com maestria, é o raciocínio condicional, que se utiliza da proposição se-então. "A proposição condicional se-então afirma que, se uma condição antecedente $p$ for atendida, então resulta em um evento consequente q." (STERNBERG, 2010, p. 447). Podemos ver um exemplo claro disso em uma passagem de seu livro "A Scandal in Bohemia", em uma de suas muitas passagens em companhia do seu fiel companheiro Watson: 
Holmes deduz que Watson tinha se molhado muito ultimamente e que ele tinha "a mais desajeitada e descuidada empregada". Quando Watson, com espanto, pergunta como Holmes sabe disso, Holmes responde: É simples [...] Meus olhos me dizem que no seu sapato esquerdo, exatamente onde a luz do fogo atinge, o couro é marcado por seis cortes quase paralelos. Obviamente eles foram causados por alguém que tenha muito descuidadamente raspado em volta das bordas da sola, a fim de remover a crosta de lama dele. Assim, você vê, minha dupla dedução que tinha saído em tempo vil, e que tinha um espécime particularmente maligna de "cortadora de botas" de Londres slavey. Sherlock Holmes (DOYLE, 1891, p. 3 , tradução nossa).

Mas como isso nos ajuda a entender o tipo de raciocínio utilizado no xadrez? É elementar, meu caro Watson! Vejamos a transcrição dessa análise de uma partida entre Kasparov e Karpov, na final do Campeonato Mundial de Xadrez, realizado em Lyon, França, em 1990, feita pelo próprio Kasparov:

Ele joga a dama para d7. Então jogo a dama para g4. Se ele capturar aqui (capturar o cavalo usando a dama) então capturo com o bispo em g7, mate. [...] Se ele capturar usando a torre, xeque (joga a dama para h5). O rei vai para g8, bispo para h7, rei para h8, bispo para g6, rei para g8, dama para h7, então mate. [...] Se ele sacrificar a dama capturando em e1, minha dama captura em e1, torre captura em d6. Depois dama e4 ameaçando o mate, então cavalo d3, dama para h4, xeque. Rei para g8, bispo captura g7, bispo também captura g7, e dama para g4. E então, sem defesa (apontando a casa onde será dado o mate indefensável) (KASPAROV'S CALCULATIONS, 2013, tradução nossa).

Percebam como Kasparov usa incessantemente os termos "se" e "então", justamente os termos-base do raciocínio condicional. É como um gato cobrindo todas as saídas que existem para um rato encurralado. Não importa a estratégia ou artimanha utilizada pelo rato: o gato já sabe o que fazer, pois raciocinou dedutivamente todas as possibilidades de fuga possíveis e todas as ações necessárias em cada uma delas.

Porém, na vida, assim como no xadrez, nada é tão simples quanto parece. Inicialmente, citei que o raciocínio é geralmente classificado em dois tipos diferentes: o raciocínio dedutivo e o raciocínio indutivo, todavia apresentei argumentos que ligam o xadrez apenas ao raciocínio dedutivo, sem citar nada do indutivo. Primeiramente, vamos à definição dada pelo mesmo autor que descreveu o primeiro, o psicólogo Robert J. Sternberg (2010, p. 446-447):

Raciocínio indutivo, em contraste, é o processo de raciocinar com base em fatos e observações específicos para chegar a uma conclusão provável que pode explicar os fatos. A pessoa que aplica o raciocínio indutivo pode usar aquela conclusão provável para tentar prever casos específicos futuros. A principal característica que distingue o raciocínio indutivo do dedutivo é que 
na indução nunca conseguimos chegar a uma conclusão logicamente correta. Somente podemos chegar a uma conclusão parcialmente bem fundamentada ou provável.

Com essa descrição, uma dúvida se instaura novamente: o jogador de xadrez utiliza o raciocínio dedutivo ou indutivo? A resposta para essa pergunta é simples: ele utiliza os dois. Exemplifico. Kasparov aplica um xeque no rei de Karpov utilizando sua dama. Ele, pelas regras do xadrez, é obrigado a pôr um fim a essa situação, ou seja, sair da situação de xeque, de ameaça ao seu rei. Porém, existe somente um lance a se fazer, que é sacrificar sua torre. Ele assim o faz. E, em menos de um segundo, Kasparov responde com outro lance magistral. Como essa situação hipotética nos ajuda a esclarecer a dúvida inicial desse parágrafo? Simples. Antes de fazer o lance, Kasparov analisa a situação e, pela posição das peças, pelo xeque em potencial e pelas regras do xadrez, ele deduz que, ao aplicar o xeque, o único lance possível é sacrificar a torre. Após ter isso em mente, ele já pensa na resposta após tal lance. Quando ele joga, o lance em resposta ao sacrifício da torre já está decidido. Isso nos mostra o poder do raciocínio dedutivo, que, utilizando os fatos e observações no tabuleiro, permite deduzir qual é o próximo lance com total certeza.

Mas já percebemos que o jogador utiliza o raciocínio dedutivo em um jogo; o que nos falta é entender como o raciocínio indutivo se apresenta diante de um tabuleiro. Revisitando a definição de Sternberg (2010, p. 446), salientamos uma passagem em específico: "para tentar prever casos específicos futuros". O jogador de xadrez tenta, a todo o momento em um jogo, prever o futuro, as jogadas, estratégias e táticas do adversário. Baseado em tais previsões, organiza seu esquema para evitar o plano do adversário e colocar o seu próprio plano em ação. Contudo, ele não pode afirmar com plena certeza qual será o próximo lance todo o tempo. Na situação anterior, isso era possível, mas, caso existissem três a quatro possibilidades de movimento para impedir o xeque, seria praticamente impossível prever qual delas seria utilizada.

Mesmo que jogadores de alto nível tenham essa capacidade mais desenvolvida, e que, geralmente, dos quatro lances, apenas um seria o melhor, ainda assim é impossível afirmar com certeza. Em vários momentos do jogo, existem dois ou três lances bons, cabendo ao jogador qual caminho seguir, tornando difícil qualquer tipo de previsão. É aí que o raciocínio indutivo se faz presente. Sternberg (2010, p. 461) expôs, em seu livro, um exemplo interessante: "Por exemplo, no 
problema da série de números $2,4,6$, ?, a maioria das pessoas substituiria o ponto de interrogação por um 8. Porém, não podemos saber com certeza que o número correto é 8". Como aplicar essa situação no xadrez? Uma abertura (lances iniciais de uma partida) muito comum no xadrez é a "Defesa Siciliana". No início do jogo, o jogador que está com as pretas joga o peão para c5 em resposta ao tradicional peão branco em e4. A variante (variações na sequência de lances) mais comum é Cf3, ou seja, as brancas jogarem seu cavalo para a casa f3 e as pretas responderem com um peão em d6. Porém, é impossível afirmar com total certeza que, em um jogo de xadrez, ao se enfrentar um jogador que inicia a Defesa Siciliana jogando o peão preto em c5, vá mover no próximo lance o outro peão para d6. Ele pode, em seu livre-arbítrio, fazer o que quiser, desde jogar a variante "Dragão Rápido" com o cavalo em c6 como levantar da mesa e desistir do jogo.

Outra passagem apresentada por Sternberg (2010, p. 462) leva novamente à utilização do raciocínio indutivo no jogo de xadrez. Ele afirmou que "Já demos a entender que o raciocínio indutivo envolve, muitas vezes, o processo de geração e teste de hipóteses". Em uma partida de xadrez, estamos, a todo o momento, raciocinando e criando hipóteses sobre qual será o próximo lance. Caso isso se confirme, seguimos a mesma linha de pensamento. Em caso contrário, abandonamos aquela linha de raciocínio e criamos outra. Wilson da Silva (2010), afirmou que, para explicar a escolha de boas jogadas que levam a vitória no xadrez, deve-se ter em consideração que, antes de efetuar sua jogada, o jogador deve levar em conta o lance que seu adversário efetuou, pensar em seu próprio próximo lance e, além disso, tentar antecipar o mais precisamente possível a resposta do adversário a esse lance. Ademais, o mesmo autor afirmou que, se esse rigor no raciocínio do jogador não for devidamente seguido, incorre a possibilidade iminente de erro e derrota.

Dessa forma, vemos que tanto o raciocínio dedutivo quanto o indutivo são utilizados no xadrez, não nos deixando dúvida da importância de se raciocinar durante o jogo, e que tal raciocínio é exigido incessantemente.

Porém, resta-nos uma dúvida: Qual é o limite entre o raciocínio dedutivo e o raciocínio indutivo? Quando um deixa de agir para o outro entrar em cena? Qual é o mais utilizado no xadrez?

Visando uma explicação mais completa, recorro aos estudiosos no ramo da economia. Um deles é W. Brian Arthur (1994), que em seu artigo intitulado "Inductive 
Reasoning and Bounded Rationality (The El Farol Problem)" aborda o que ele chama de "Racionalidade limitada".

Arthur (1994) afirma que, quando a racionalidade dedutiva não é possível, ou seja, quando a racionalidade é limitada, devido à complexidade ou incerteza da situação, o ser humano recorre aos métodos indutivos de raciocínio.

Um exemplo clássico disso é o problema do "El Farol Bar:

Imagine que $\mathrm{N}$ pessoas decidem independentemente toda semana a ir ou não a um bar que oferece entretenimento determinada noite. Vamos fixar o valor de $\mathrm{N}$ em 100, para facilitar o raciocínio. Como o espaço é restrito, então o ambiente é agradável se menos que 60 das 100 pessoas estiverem presentes. Acima disso, o ambiente fica desconfortável, tornando a experiência desagradável. Não existe possibilidade de saber o número de pessoas que vão, pois não há comunicação entre os agentes. Dessa maneira, um agente vai, se ele acredita que estarão presentes menos de 60 pessoas, ou ele fica em casa se acredita que mais de 60 das pessoas irão ao bar.

A única informação disponível que possa guiar a decisão de cada agente é o número de pessoas que foram ao bar nas semanas anteriores (ARTHUR, 1994, p. 408, tradução nossa).

Arthur (1994) destaca que não existe um modelo para que os agentes possam basear suas decisões; logo, não é possível uma solução dedutiva. Cada agente não tem conhecimento da estratégia que será utilizada pelos outros agentes, tornando-se um problema maldefinido do ponto de vista dos agentes, o que leva a um processo de indução.

Além disso, se todos os agentes utilizarem a mesma estratégia, ela se torna inválida, pois ou o bar ficará lotado ou ficará completamente vazio. Logo, todas as hipóteses são forçadas a divergir. Nessa situação, nenhum raciocínio dedutivo pode ser utilizado, restando apenas o raciocínio indutivo.

Arthur também utiliza o xadrez para analisar uma situação em que se vê necessário recorrer ao raciocínio indutivo.

Nós podemos ver o comportamento indutivo em funcionamento no jogo de xadrez. Jogadores normalmente estudam a atual configuração do tabuleiro, e recordam os lances do seu oponente em jogos passados, para discernir padrões (De Groot, 1965). Eles utilizam tais padrões para formar hipóteses ou modelos internos sobre as intenções de estratégia uns dos outros, talvez mantendo inúmeras em sua mente de uma única vez: "Ele está usando uma defesa Caro-Kann." "Isso parece um pouco com o jogo 1936 BotvinnikVidmar." "Ele está tentando construir sua formação de peões no meio do tabuleiro." Eles fazem deduções locais baseadas nisso - analisando as implicações possíveis de lances muitas jogadas à frente, de forma profunda. E assim que o jogo se desenrola eles se agarram a hipóteses ou modelos mentais que se comprovam plausíveis, ou joga-os fora, gerando novos para colocar em seu lugar. Em outras palavras, eles usam uma sequência de 
reconhecimento de padrões, formação de hipóteses, dedução de hipóteses atualmente existentes, e substituição de hipóteses, conforme necessário (ARTHUR, 1994, p. 405, tradução nossa).

Isso mostra que o jogador de xadrez utiliza, concomitantemente, os raciocínios dedutivo e indutivo, em busca do melhor lance a ser executado. $O$ raciocínio dedutivo é utilizado quando a situação é simples e bem definida, como no caso de um ataque direto ao rei com apenas uma ou duas opções de saída. Já o raciocínio indutivo é utilizado em situações complexas e maldefinidas, como em uma abertura que possui inúmeras variantes diferentes de igual ou semelhante força, em que a escolha de qual abertura utilizar se deve ao fator estilo ou preferência do jogar. Nesses momentos, o raciocínio indutivo entra para preencher as lacunas que o raciocínio dedutivo deixa, buscando padrões, formulando hipóteses e validando-as ao longo do jogo. Arthur (1994, p. 405, tradução nossa) cita isso diretamente no seguinte trecho de sua obra:

\begin{abstract}
Como seres humanos raciocinam em situações que são complexas ou maldefinidas? A psicologia moderna nos diz que, como seres humanos, nós somos apenas moderadamente bons em lógica dedutiva, e fazemos um uso apenas moderado dela. Mas nós somos magníficos ao ver ou reconhecer ou correlacionar padrões - comportamento este que nos confere óbvios benefícios evolutivos. Então, em problemas complexos, procuramos por padrões; e simplificamos o problema usando isso para construir modelos internos temporários ou hipóteses ou esquemas com que possamos trabalhar. Realizamos deduções localizadas com base em nossas hipóteses atuais e agimos de acordo com elas. Assim que o feedback do ambiente se apresenta, podemos fortalecer ou enfraquecer nossas crenças em nossas hipóteses atuais, descartando algumas quando deixam de funcionar, substituindo-as por novas quando necessário. Em outras palavras, onde não podemos raciocinar plenamente ou não temos uma definição completa do problema, usamos modelos simples para preencher as lacunas em nossa compreensão. Tal comportamento é indutivo.
\end{abstract}

Como havia afirmado anteriormente, em nada importa o fato de que 0 raciocínio seguido está perfeitamente correto ou se está equivocado, bem como se ele é ou não o mais adequado para a situação.

Saber mais sobre cada tipo de raciocínio utilizado em uma partida de xadrez ajuda a entender o porquê desse jogo de regras e constituição simples pode ser tão complexo e multifacetado. Em cada jogada, ou seja, em uma média de 40 vezes por partida, o jogador deve raciocinar profundamente, buscar padrões, criar e testar hipóteses, coletar resultados para reforçar ou refutar essas hipóteses, criar novas para substituir as que não se concretizaram, chegar a conclusões de problemas 
complexos e agir de forma acertada, tudo isso em um tempo limitado. É justamente essa cadeia de pensamento que torna o xadrez uma valorosa ferramenta para 0 desenvolvimento de habilidades cognitivas. Esse esforço e dedicação, além dessa profunda e repetitiva análise em busca do melhor lance são os fatores que realmente potencializam o desenvolvimento do raciocínio. Não é o resultado que importa, mas sim o caminho que foi percorrido para se chegar a ele. É como se ver diante de duas ou mais portas, e decidir qual delas se deve abrir e entrar. Não importa se a que se escolheu foi a correta, mas sim o processo mental utilizado para definir qual porta se deve abrir.

John Dewey (1959) também discorreu sobre esse tema. Utilizando o termo "pensamento" ao invés de raciocínio, o autor afirma que, para ele entrar em ação, é necessária uma dúvida, um dilema, uma decisão a ser tomada que envolva mais de uma resposta. Para ele, o momento inicial no qual nos vemos compelidos a usar o raciocínio é quando nos deparamos com uma "[...] bifurcação de caminhos, uma situação ambígua, que apresente um dilema, que propõe alternativas" (DEWEY, 1959, p. 2).

De acordo com o autor, quando nos deparamos com uma situação que não se configura uma dúvida, um problema a resolver, uma dificuldade a superar, uma saída a se encontrar, acabamos por dar um parecer totalmente desprovido de reflexão, e sugerimos algo ao acaso, ou seja, o que vier primeiro à mente. Porém, diante de uma dificuldade, nosso pensamento segue um fluxo bem definido, que se inicia na sugestão de uma solução, isto é, como afirmamos anteriormente, a criação de uma hipótese.

\subsubsection{A importância da memória para o raciocínio}

Seguindo o raciocínio, vemos que, para se solucionar um problema, criamos uma hipótese e, posteriormente, testamos e avaliamos se ela está correta ou não. Porém, de onde tal hipótese surge?

Dada uma dificuldade, a fase imediata é a sugestão de algum meio de sair dela - é tentar organizar algum plano ou projeto, ou elaborar alguma teoria que explique as particularidades em questão, examinar alguma solução para o problema. Os dados de que dispomos não podem proporcionar a solução; limitam-se a sugeri-la. Quais são, pois, as fontes de sugestão? É óbvio que a experiência passada, um cabedal de conhecimentos úteis disponíveis. Se estivermos familiarizados com situações análogas, se já nos 
preocupamos antes com uma questão semelhante, é provável que surjam sugestões mais ou menos adequadas e eficientes (DEWEY, 1959, p. 24).

No trecho acima, vemos a importância de uma outra habilidade cognitiva, que auxilia o raciocínio: a memória.

A memória é parte importante no processo de criação de hipóteses e na busca por padrões. Como citado anteriormente por Arthur (1994, p. 405, tradução nossa): "Ele está usando uma defesa Caro-Kann." "Isso parece um pouco com o jogo de 1936 Botvinnik-Vidmar." "Ele está tentando construir sua formação de peões no meio do tabuleiro."

Todos esses padrões sugeridos são advindos da comparação entre a situação atual do tabuleiro com situações armazenadas na memória. Situações essas que podem ter sido jogos entre grandes mestres e aberturas catalogadas (como no exemplo citado por Arthur), ou mesmo partidas anteriores do adversário. $\mathrm{O}$ aparato fornecido pela memória dá maior capacidade de encontrar padrões e reduzir o tempo e o esforço na obtenção de uma "saída". Ao se observar um padrão na configuração das peças no tabuleiro, é possível afirmar, com uma probabilidade maior de acerto, de que o próximo lance será idêntico ao utilizado em uma situação anterior pelo mesmo adversário. Se já nos preocupamos anteriormente com essa situação, por que o fazer novamente? Como citado por Dewey (1959, p. 24), "se já nos preocupamos antes com uma questão semelhante, é provável que surjam sugestões mais ou menos adequadas e eficientes".

Porém, ao inserir a memória como fator determinante no sucesso do fluxo de raciocínio, inserimos também um problema quando nos referimos às crianças que nunca tiveram contato com o xadrez, como é o caso do presente estudo. Como raciocina uma pessoa que não teve nenhuma experiência anterior que possa the guiar na formulação de uma hipótese? Como funciona o raciocínio sem a participação ativa da memória? Como um jogador inexperiente chega à conclusão de que lance deve executar? Para responder a essa dúvida, vamos raciocinar juntamente com Dewey (1959, p. 24):

Mas, não havendo alguma experiência análoga, a confusão continuará a ser confusão. Mesmo quando uma criança (ou um adulto) se acha embaraçada com algum problema, é inteiramente inútil exortá-la a pensar a respeito, quando ainda não possui experiência própria em condições aproximadas às presentes. 
Portanto, ao afirmar isso, estamos assumindo que de nada adianta pedir a uma criança, que nunca jogou xadrez, para que pense antes de jogar? Não podemos exigir que ela mergulhe em um fluxo de raciocínio que a possibilite chegar à decisão do melhor lance a ser executado, simplesmente por ela não ter experiências anteriores que as guiem?

A resposta para todas essas perguntas é: Não. Arthur (1994), inicialmente, disse que o processo de raciocínio em um jogo de xadrez envolve, constantemente, a criação, avaliação e renovação de hipóteses. Porém, ele não disse que isso acontece a cada jogo, mas sim a cada LANCE. Ou seja, você aprende a cada novo lance executado. Por exemplo, um jogador formula uma hipótese no lance 12 e obtém o feedback no lance 13, refutando ou reforçando essa hipótese, o que já lhe confere uma experiência que the guie no restante do jogo. Um jogador iniciante e inexperiente, obviamente, não apresentará força o suficiente para vencer um jogador com anos de experiência, mas isso não o impede de raciocinar, igual ou até mais profundamente, do que um jogador veterano.

O fator de grande influência na vitória de um veterano está na sua experiência, ou seja, na sua memória. "Se já nos preocupamos anteriormente com essa situação, por que o fazer novamente?" (DEWEY, 1959, p. 24). Essa frase resume o ponto-chave que define a superioridade de um veterano sobre um iniciante. O veterano já enfrentou as mais diversas situações-problema em jogos anteriores, armazenando de forma eficaz qual foi a melhor saída por ele encontrada. Digo isso pois em sua memória também estão registrados os lances e combinações ruins, as quais levaram-no à derrota. Resumindo, em sua memória existem duas vertentes que direcionam suas decisões: o melhor e o pior a ser feito.

De Groot (1978), que realizou estudos envolvendo jogadores dos mais variados níveis de expertise no xadrez, confirmou a importância da memória, alegando que ela é um fator determinante na habilidade enxadrística. Em seu estudo, uma das atividades propostas era de apresentar uma posição em um tabuleiro, com peças e posições variadas, durante determinando tempo (entre 2 a 10 segundos). Passado o tempo, a posição era removida, cabendo aos sujeitos reproduzirem da forma mais aproximada possível a localização das peças em outro tabuleiro. O sucesso foi mensurado de acordo com a quantidade de peças corretas colocadas nos locais corretos. Ao final de seu estudo, ficou óbvia a diferença entre a memória de jogadores mais experientes e jogador iniciantes. Os GMs, sigla que 
representa o título de Grande Mestre, um dos títulos vitalícios concedidos pela FIDE (Fédération Internationale des Échecs) aos enxadristas profissionais que tenham obtido a pontuação igual ou superior a 2.500 pontos em, pelo menos, 24 partidas válidas pelo rating da FIDE, obtiveram a maior porcentagem de acertos possível (22 acertos). Já os jogadores mais inexperientes acertaram apenas 9 das 22 peças disponíveis, totalizando $41 \%$ de acerto. Os GMs mais experientes apresentaram índices de memória elevados em comparação a todos os outros níveis de expertise abaixo dos seus.

Tabela 2 - Resultados obtidos por De Groot (1978) em seu estudo, organizados de acordo com a quantidade/porcentagem de erros e acertos na reprodução da posição

Tabulated Results

Position VI: taken from a game Rohacek-Rabar (after the 2oth move by While).

Points $\quad \%$ correct $\quad$ defect $\%$

\begin{tabular}{lrrr} 
Maximum & 22 & 100 & 0 \\
\hline Subject G & 22 & 100 & 0 \\
Subject M & 21 & 95 & 5 \\
Subject E & 16 & 73 & 27 \\
Subject C & 9 & 41 & 59
\end{tabular}

Fonte: De GROOT (1978, p. 328).

Na tabela acima, retirada diretamente do estudo de De Groot (1978), vemos que o jogador mais experiente (Subject $G$ ) acertou a localização de $100 \%$ das peças. Já o jogador de nível inferior cometeu erros quase que de acordo com seu nível, ou seja, quanto mais inexperiente, mais erros foram cometidos.

De Groot (1978, p. 329, tradução nossa) afirmou que, "De acordo com esse material é evidente que 'experiência' é a base para as realizações superiores dos mestres". Cabe ressaltar que tal estudo avalia a memória "para assuntos enxadrísticos", ou seja, utilizando peças dispostas em um tabuleiro de xadrez, situação essa que faz parte do cotidiano dos sujeitos entrevistados. Portanto, a transferência dessa habilidade não foi avaliada, sendo impossível afirmar, apenas com este estudo, que a memória desenvolvida no xadrez possa ser aplicada em situações cotidianas, como lembrar de um número de telefone, de um endereço ou data. Mesmo que ainda não tenha sido devidamente provada a capacidade da 
transferência da habilidade cognitiva "memória" do xadrez para outras atividades, já é corroborada cientificamente a possibilidade de se "treinar" a memória. De acordo com Miller (1956, p. 91, tradução nossa), esse "treino" consiste basicamente no desenvolvimento da habilidade de "recodificar" os dados e informações em processo de constante entrada:

No jargão da teoria da comunicação, este processo seria chamado de recodificação. A entrada é dada em um código que contém muitos pedaços com poucos bits por pedaço. $O$ operador recodifica a entrada em outro código que contém menos pedaços com mais bits por pedaço. Há muitas maneiras de fazer essa recodificação, mas provavelmente o mais simples é o de agrupar os eventos de entrada, aplicar um novo nome para o grupo e, em seguida, lembrar-se do novo nome, em vez dos eventos de entrada originais.

Isso mostra que a capacidade de armazenamento de informações na memória de curta duração é plenamente possível de ser ampliada. O segredo está na reorganização das informações já adquiridas, bem como as novas que estão em constante processo de entrada. Sem dúvidas, adquirir, processar, armazenar e utilizar dados e informações são habilidades constantemente requisitadas em uma partida de xadrez, bem como na vida acadêmica.

\subsubsection{A importância do fator emocional na tomada de decisões}

"Mestre, como faço para me tornar sábio? - Boas escolhas. -
Mas como fazer boas escolhas? - Experiência - diz o mestre.
- E como adquirir experiência? - Más escolhas." (autor
desconhecido)

Um dos melhores modos de se adquirir experiência é por meio do erro. Sendo assim, o xadrez constitui-se como um instrumento capaz de proporcionar a oportunidade do erro sem consequências severas.

Ou seja, ele propicia uma liberdade para que seu aluno erre sem temer as consequências. Em um mundo onde ele tem poucas oportunidades de decidir, a partida de xadrez passa a ter uma função privilegiada, pois cada lance é precedido de uma análise e de uma tomada de decisão, o que contribui para o treinamento dessas habilidades (FREIRE et al., 2005, p. 151).

Porém, devemos ter cuidado ao afirmar que o erro no xadrez não traz consequências severas, principalmente ao se falar sobre crianças. Uma partida de 
xadrez para uma criança constitui-se em um mundo de fantasia, que naquele momento em específico, torna-se real. E sendo um mundo considerado real, tem consequências reais, tais como angústia, medo e frustração, que muitas vezes se exteriorizam de forma real e até perigosa. Esse talvez seja o ponto crucial no desenvolvimento emocional potencializado pelo xadrez, pois uma das grandes contribuições desse jogo está na sua capacidade de promover situações em que a criança enfrente a frustração e o erro. Ao professor, cabe o papel de "ensinar" a criança sobre como lidar com as mais variadas emoções que ela externaliza (ou internaliza) diante do erro. Tristeza, raiva, arrependimento e indiferença são exemplos de sentimentos vivenciados por um jogador que comete um erro. $\mathrm{E} o$ desencadeamento de atitudes e ações advindas desses sentimentos também são as mais variadas possíveis. Algumas choram e desistem do jogo, ou apresentam acessos de raiva e derrubam as peças, ou até mesmo formulam desculpas complexas e elaboradas para justificar o erro. Em uma sociedade na qual pais e mães se mostram cada dia mais permissivos, é de suma importância criar mecanismos que possam permitir que a criança enfrente situações de frustração, orientando-a sobre como reagir e controlar seus sentimentos da forma mais adequada.

O professor/educador pode ser um importante colaborador não só da educação formal, da construção da cidadania, mas também da construção do sujeito. Portanto, a forma como lida com as crianças, particularmente com suas emoções (por exemplo, se fica indiferente, utiliza repreensões ou permissões), interferirá no desenvolvimento infantil (com repercussões na vida adulta) (SOUZA, 2013, p. 24).

Seja diante da alegria da vitória, da tristeza da derrota, do arrependimento do lance errado ou da ansiedade da espera, a criança deve saber qual a melhor forma de reagir. Novamente, encontramo-nos diante de uma "[...] bifurcação de caminhos, uma situação ambígua, que apresente um dilema, que propõe alternativas" (DEWEY, 1959, p. 23). Devo conter minha raiva por ter perdido ou posso expressála de alguma forma? Por que todos dizem que devo contê-la? Porque não posso expressar toda a raiva que sinto? Talvez esse seja um diálogo comum na mente de uma criança que se vê diante da fatídica derrota. Muitas delas, não instruídas sobre como reagir, agem de forma agressiva, derrubando as peças ou até mesmo agredindo fisicamente o adversário. Diante de tais atitudes, Souza (2013, p. 27) afirma que: 
Quando demonstram emoções autênticas e estas são desqualificadas ou censuradas, as crianças aprendem a mascará-las, disfarçá-las. Em nossa sociedade/cultura há um convite ou uma permissão para que sintamos e/ou demonstremos algumas emoções e não outras. Quando ocorrem ataques sistemáticos à capacidade de expressar emoções, acontece um processo de treinamento/aprendizagem no sentir algumas emoções e não outras.

Novamente, o xadrez proporciona à criança a necessidade de se raciocinar sobre a melhor decisão a ser tomada. Ela pode externar seus sentimentos e ser, assim, repudiada pelos demais. Ou, então, ela pode controlar tais sentimentos, agindo de forma centrada e correta diante do seu adversário, professor ou colega. Essa situação de conflito é facilmente observada em torneios escolares de xadrez. Em situações de competição explícita, as "travas" emocionais impostas pela sociedade, muitas vezes, mostram-se fracas, pois, devido à pressão do momento, muitas crianças externalizam sentimentos ora retraídos.

\begin{abstract}
A ansiedade sempre se encontra presente nas crianças, especialmente quando participam pela primeira vez de uma competição ou um campeonato. Mesmo dentro de um ambiente conhecido, as expectativas, muitas vezes relacionadas às cobranças dos pais ou da própria criança, são adensadas, podendo atrapalhar a concentração necessária ao momento do jogo (CHRISTOFOLETTI, 2007, p. 49).
\end{abstract}

É comprovado que a emoção influencia diretamente na tomada de decisões. A eterna luta entra a razão e a emoção, eternizada em poemas pelo mundo, é também parte constituinte de estudos científicos. Damasio (1994) foi um dos estudiosos que pesquisou sobre a influência da emoção no raciocínio e na tomada de decisões, criando a "hipótese do marcador somático". Essa hipótese sugere que "uma situação se une a um estado somático específico, e é este padrão somatosensorial, ou marcador somático que qualifica uma situação como boa ou má" (BUTMAN; ALLEGRI, 2001, p. 276). Em um de seus principais estudos, buscouse comparar o processo de tomada de decisões de pacientes com diferentes níveis de lesões cerebrais no sistema límbico, ou córtex frontal do cérebro, o qual é responsável pelas emoções. Ao final, foi possível observar que pacientes com lesão no córtex pré-frontal ventromedial apresentaram "falhas na utilização de sinais somáticos ou emocionais para guiar a conduta" (BUTMAN; ALLEGRI, 2001, p. 276). Esse "marcador somático" pode ser traduzido, com auxílio do vocabulário popular, como "cérebro de lagarto" ou "sexto sentido", ou até mesmo com o auxílio de Stan Lee e seu famoso personagem Homem Aranha, o qual possui o "sensor aranha", 
que alerta-o do perigo iminente, antes mesmo que ela tome consciência dele. Esse sentido alerta o corpo sobre uma determinada decisão, avaliando-a automaticamente, de forma inconsciente, e classificando-a em boa ou má decisão. Portanto, pacientes com lesões nessa área geralmente "[...] se mostram alheios às futuras consequências de seus atos e atuam segundo suas perspectivas imediatas" (BUTMAN; ALLEGRI, 2001, p. 276).

Um exemplo simples pode ser o de uma pedra vindo em sua direção. Quando alguém lhe atira um objeto, você tem, basicamente, duas opções: desviar ou deixar o objeto lhe atingir. Porém, a situação requer uma decisão imediata, da qual não se pode esperar um conhecimento consciente para realizá-la. Nessa situação, ninguém pensa "Devo desviar ou ser atingido?", pois, em situação anterior, percebeu-se que ser atingido é a pior escolha possível. Portanto, o conhecimento consciente foi adquirido anteriormente, sendo armazenado no cérebro de forma a facilitar decisões posteriores, acelerando-as. Tendo essa informação em mente, de forma inconsciente, o cérebro é capaz de ligar diretamente o estímulo desencadeador da resposta mais vantajosa, de forma a se acionar esse mecanismo rápida e automaticamente. Ou seja, ao observar um objeto sendo atirado em sua direção, você imediatamente desvia, agindo por puro "reflexo".

A aparente frieza de raciocínio prejudica a tomada de decisões, já que os marcados emocionais são parte determinante do processo. Damasio (1994 apud OLIVA et al., 2006, p. 57-58) concluiu que:

\begin{abstract}
Nas relações que se estabelecem entre as pessoas, tomar uma decisão envolve analisar vantagens e desvantagens, ganhos e perdas, nas mais variadas instâncias sociais. O comportamento de decidir sobre algo parece incluir, de acordo com Damásio, uma atividade cerebral explícita (sob o domínio de estruturas ou mecanismos cognitivos) e outra implícita (sob o domínio de mecanismos emocionais). Por exemplo, quando são usados comportamentos cooperativos ou competitivos, as pessoas ponderam sobre o que vão ganhar e perder e agem, muitas vezes, visando um ganho imediato mesmo que venham a perder a longo prazo. Isto pode ser indicativo da predominância de um mecanismo emocional nessa decisão.
\end{abstract}

Como pudemos ver, na vida, assim como no xadrez, muitas (ou até mesmo todas) das decisões por nós tomadas são influenciadas pela emoção. Controlar e direcionar as emoções em prol de um objetivo, ou da melhor decisão, são tarefas cotidianas de qualquer ser humano que viva em sociedade. De acordo com as palavras do próprio Damásio (1994, p. 52, tradução nossa): 
Nunca houve qualquer dúvida de que, sob certas circunstâncias, as emoções perturbam 0 raciocínio. As evidências são abundantes e constituem a fonte para os bons conselhos com o qual temos sido criados. Mantenha a cabeça fria, mantenha as emoções afastadas! Não deixe que as paixões interfiram em seu julgamento.

E, como foi afirmado anteriormente, o xadrez é um instrumento capaz de proporcionar constantes momentos em que é necessário manter a "cabeça fria e as emoções afastadas", evitando, dessa forma, que as "paixões interfiram em seu julgamento". Assim como Freire et al. (2005) também confirmaram, o xadrez propicia uma liberdade para que quem o joga possa errar sem temer as consequências. Isso propicia momentos de aprendizagem únicos para a criança, permitindo experimentar, em um ambiente amigável, as consequências dos seus atos, vendo, na prática, que más decisões levam a consequências ruins.

\subsection{O QUE É EXPERTISE?}

Para iniciarmos a busca por responder essa questão, veremos um trecho retirado do estudo de Silva (2010, p. 87):

O termo expert é geralmente empregado para definir alguém muito
habilidoso e bem informado em algum campo especial, ou para alguém
amplamente reconhecido por seus pares como uma fonte confiável de
conhecimento, técnica ou habilidade. Experts têm experiência prolongada
ou intensa através de prática e estudo em um campo particular. Expertise
então se refere às características, habilidades e conhecimentos que
distinguem experts de novatos e de pessoas menos experientes.

De acordo com Ericsson (1996), estudar a expertise constituiu um grande desafio aos cientistas, pois a maioria das evidências da existência de experts em determinadas áreas era baseada em fatos e "anedotas" impossíveis de serem comprovados, sendo, muitas vezes, histórias contadas pelos próprios experts, relatando seus feitos. Portanto, o estudo da expertise apresenta grandes complicadores, que residem, principalmente, na dificuldade de identificação e catálogo sistemático de evidências empíricas. Sobre isso, Ericsson (1996, p. 1, tradução nossa) afirma que, para o estudo confiável da expertise, é necessário que: 
identificação e acúmulo sistemático de todas as evidências empíricas que atendam aos critérios científicos padrão.

Porém, em alguns casos, essa não é uma tarefa fácil. Em alguns esportes, como a ginástica, a performance é avaliada por termos relativos, baseados na comparação com outros atletas contemporâneos, o que dificulta um padrão global para mensurar a performance de um atleta. Entretanto, em outros âmbitos, como o xadrez ou tênis, os resultados em jogos e torneios podem ser analisados por rankings individuais, denotando, assim, o nível de expertise individual de acordo com a sua colocação em determinando ranking. Também existem diversos âmbitos em que performances superiores são observadas por meio de testes e condições padronizadas. Certas atividades que envolvem habilidade motora, como uma corrida de 100 metros, por exemplo, são medidas pelo tempo. Não apenas nos esportes, mas em outras inúmeras áreas, a expertise pode ser observada. Porém, Ericsson (1996, p. 3, tradução nossa) encontrou resultados curiosos quando profissionais considerados experts foram submetidos a testes em condições padronizadas. De acordo com ele, "a suposição de que profissionais considerados experts devem apresentar um desempenho superior em atividades relevantes do seu domínio não foi comprovada quando os testes foram realizados sob condições padronizadas".

Ao rever as definições e estudos apresentados sobre expertise, resta-nos a seguinte dúvida: a expertise só pode ser adquirida com a experiência, descartandose, assim, a existência de um talento nato? Com essa pergunta, voltamos a uma das primeiras páginas do presente estudo, em que Edward Lasker (1999, p. 163) afirmou que, "Na música, no xadrez ou na matemática, a experiência não é necessária". Sloboda (1996, p. 107) aborda esse tema, citando-o em um capítulo intitulado "A aquisição de expertise na performance musical: desconstruindo o peso do 'Talento' nas diferenças individuais da expressividade musical". Nele, o autor expõe basicamente que talento nada mais é do que a crença de que o indivíduo nasceu com uma habilidade especial para certa atividade, que no caso foi a música, mas bem poderia ser o xadrez, a culinária, o basquete ou a engenharia de computação. Davis (1994) mostrou, em seu estudo, que $75 \%$ da sua amostra, composta principalmente por profissionais da educação, acreditam que atividades como compor, cantar e tocar um instrumento musical exigem um dom especial ou talento natural. Já menos de $40 \%$ da amostra acreditam que tal talento nato é 
extremamente necessário em atividades como jogar xadrez, realizar uma cirurgia ou escrever um livro.

Muitas teorias foram formuladas visando explicar por que pessoas possuem níveis diferentes de habilidades cognitivas.

\begin{abstract}
Entre as respostas mais proeminentes, estão as de que o desempenho cognitivo depende dos genes, de habilidades gerais, de experiências de vida, ou do conhecimento especializado que foi aprendido. Quem está certo? [...] Os estudos com gêmeos mostram uma forte correlação entre os resultados dos testes cognitivos de gêmeos idênticos criados separadamente, sugerindo evidência para a explicação dos genes. Pontuações em testes de habilidade cognitiva geral conseguiram predizer com sucesso o quão bem os alunos iriam em testes escolares, sugerindo evidências para a explicação das habilidades gerais. Os estudantes de música cujos pais incentivaram a participação em grande quantidade de atividades desafiadoras são mais propensos a se tornarem pianistas realizados, sugerindo evidência para a explicação da experiência de vida. Finalmente, as pessoas que aprenderam estratégias específicas de como se lembrar de uma lista de dígitos obtiveram excelência em tarefas de extensão de dígitos, o que sugere a evidência para a explicação do conhecimento especializado (MAYER, 2003, p. 264, tradução nossa).
\end{abstract}

Ericsson, Krampe e Tesch-Romer (1993) forneceram evidências convincentes para a conclusão de alguma generalidade com relação ao desenvolvimento da expertise. Sua conclusão foi de que o nível de expertise é uma função direta da quantidade de prática formal de esforço dessa habilidade empreendida por um indivíduo. Ou seja, a prática leva à perfeição. Charness, Krampe e Mayr (1996) estudaram a influência da quantidade (e direcionamento) de tempo gasto com a prática e estudo do xadrez na expertise enxadrística. Eles encontraram dados interessantes, principalmente no que se refere à prática solitária. Praticar sozinho, em comparação a praticar em público (como em torneios, por exemplo), demonstrou melhores resultados ao fim do estudo. Para explicar melhor a falha na concepção de "talento nato", os autores citam a seguinte situação hipotética:

Imagine dois jogadores hipotéticos, $X$ possui um rating de 2200 , e $Y$ possui um rating de 1800. $O$ Jogador $Y$ observa que 0 jogador $X$ joga aproximadamente o mesmo número de torneios que ele, e que o jogador $X$ se envolve em análises pós jogo tão frequentemente quanto 0 jogador $Y$. Assim, a sua diferença em relação ao rating deve ser devido ao fato de que $\mathrm{o}$ jogador $\mathrm{X}$ é mais talentoso do que jogador $\mathrm{Y}$. $\mathrm{O}$ fator ausente pode ser $\mathrm{O}$ que $X$ e $Y$ fazem fora do clube de xadrez ou salão do torneio. Jogador $X$ pode estar estudando uma hora por dia a mais do que o jogador $\mathrm{Y}$, e estudando de forma mais eficaz (CHARNESS; KRAMPE; MAYR, 1996, p. 76). 
Portanto, ainda é controverso o assunto que aborda o talento nato, bem como os fatores que influenciam a expertise. Cabe-nos analisar as diversas teorias e levar em consideração a que mais se aplica a habilidade em questão, que é a enxadrística, mas sem descartar completamente as demais teorias. Assim como é característico do próprio jogo de xadrez, a imensidão de possibilidades também se aplica quando buscamos descobrir qual fator desempenha maior influência na expertise enxadrística. Genética, prática e questões ambientais são os temas que figuram em maior quantidade os estudos sobre tal assunto, mas nenhum deles chegou a resultados conclusivos que nos permitam afirmar por que uma criança joga xadrez de forma excelente, chegando a vencer adultos com anos de experiência, e outras mal conseguem vencer crianças da mesma idade. 


\section{METODOLOGIA}

\subsection{OBJETIVO GERAL}

Analisar o desempenho de crianças no Teste Não Verbal de Raciocínio Infantil e comparar seu desempenho com o de crianças que frequentaram o reforço escolar, a fim de verificar a existência de diferenças estatisticamente significativas entre o desempenho dos grupos, sugerindo assim uma possível influência da prática do xadrez no raciocínio infantil.

\subsection{OBJETIVOS ESPECÍFICOS}

a) Verificar se existem diferenças estatisticamente significativas entre 0 desempenho de crianças do sexo masculino e crianças do sexo feminino no TNVRI;

b) verificar se existe correlação entre a expertise enxadrística e o escore obtido no Fator Geral do Pós-Teste do TNVRI.

\subsection{HIPÓTESE DE PESQUISA}

Os indivíduos que frequentaram aulas de xadrez terão desempenho superior no Fator Geral do TNVRI - Teste Não Verbal de Raciocínio Infantil, quando comparados aos indivíduos que frequentaram aulas de reforço e aos indivíduos que não frequentaram aulas extras.

\subsection{NATUREZA DA PESQUISA}

Com base nos objetivos, este estudo é de natureza explicativa, pois tem "como preocupação central identificar os fatores que determinam ou que contribuem para a ocorrência dos fenômenos" (GIL, 2002, p. 42). O fenômeno estudado é o desenvolvimento do raciocínio, sendo a prática do xadrez como fator determinante para ele. A hipótese que se deseja refutar ou confirmar é a de que a prática do xadrez influencia positivamente no desenvolvimento do raciocínio, mais do que aulas de reforço. A comparação com um grupo que frequentou o reforço escolar e outro 
grupo que não desempenhou nenhuma atividade extra vai ao encontro das recomendações de Campitelli e Gobet (2007), nas quais ele afirmaram que é esperado que o grupo experimental, ou seja, o grupo que praticou xadrez, obtenha desempenho superior ao ser comparado com dois grupos controle. O primeiro grupo controle deveria ser composto por indivíduos que receberiam um tratamento alternativo (sendo o reforço escolar o tratamento alternativo escolhido no presente estudo), e o segundo deveria receber nenhum tratamento. Esse esquema exclui a justificativa de que o incremento observado no grupo experimental fosse advindo apenas da participação em alguma atividade extra, seja ela qual for. Com isso, é possível concluir que o efeito se deve a características presentes apenas no grupo de tratamento. De acordo com Gil (2002, p. 42), "Esse é o tipo de pesquisa que mais aprofunda o conhecimento da realidade, porque explica a razão, o porquê das coisas".

O delineamento metodológico caracteriza o estudo como uma pesquisa experimental. Portanto, vai de acordo com Gil (2002, p. 43), que afirmou que "as pesquisas explicativas nas ciências naturais valem-se quase exclusivamente do método experimental". A pesquisa experimental pode ser descrita em três características básicas: 1) determinar um objeto de estudo; 2) selecionar as variáveis que seriam capazes de influenciá-lo; 3) definir as formas de controle e de observação dos efeitos que a variável produz no objeto. Gil (2002) afirmou que é razoavelmente simples controlar as variáveis em estudos que envolvam entidades físicas, tais como porções de líquidos, bactérias ou ratos. Porém, quando se objetiva experimentar objetos sociais, tais como pessoas, grupos ou instituições, as limitações são bem evidentes. Mas que, mesmo com tais dificuldades, ainda são frequentes experimentos nas ciências humanas, sobretudo na psicologia (por exemplo: aprendizagem). Gil (2002, p. 48) elogiou a escolha da pesquisa experimental como delineamento de pesquisa:

A pesquisa experimental constitui o delineamento mais prestigiado nos meios científicos. Consiste essencialmente em determinar um objeto de estudo, selecionar as variáveis capazes de influenciá-lo e definir as formas de controle e de observação dos efeitos que a variável produz no objeto. Trata-se, portanto, de uma pesquisa em que o pesquisador é um agente ativo, e não um observador passivo. 


\subsection{SUJEITOS}

Foram selecionados, por conveniência, 36 sujeitos de uma escola pública da zona rural do Distrito Federal, com idade entre 7 anos e 8 anos e 9 meses (média 7 $\pm 0,58$ d.p), matriculados entre $\circ 2^{\circ}$ e $\circ 3^{\circ}$ ano do ensino fundamental. Os sujeitos selecionados foram divididos em três grupos: um grupo experimental e dois grupos controle. Cada grupo foi composto por 12 sujeitos, escolhidos aleatoriamente em três turmas presentes na escola em questão. O grupo experimental (GEX) frequentou duas aulas de xadrez por semana, com duração de uma hora cada. $O$ grupo controle 1 (GC1) frequentou duas aulas de reforço escolar por semana, também com duração de uma hora cada. O grupo controle 2 (GC2) não recebeu nenhum tratamento ou intervenção extra. A presença desse segundo grupo controle vai ao encontro das recomendações apresentadas por Campitelli e Gobet (2007), que utilizaram como justificativa o argumento de que essa estratégia elimina a possibilidade de o efeito da prática do xadrez não ser atribuído a alguma característica do grupo experimental, mas $\operatorname{sim}$ a fatores inespecíficos, como a participação em um experimento ou o simples fato de estarem realizando uma atividade extra.

\subsubsection{Critérios de inclusão na pesquisa}

a) Sujeitos que se declararam disponíveis e interessados em frequentar as aulas de xadrez e de reforço escolar;

b) sujeitos em que o Termo de Consentimento Livre e Esclarecido foi assinado por seus responsáveis;

c) sujeitos que declararam não ter tido nenhum tipo de instrução enxadrística anterior à pesquisa.

\subsubsection{Critérios de exclusão da pesquisa}

a) Sujeitos em que o Termo de Consentimento Livre e Esclarecido não foi assinado por seus responsáveis;

b) sujeitos que demostraram ter tido algum tipo de instrução enxadrística anterior à pesquisa; 
c) sujeitos que apresentaram frequência inferior a $75 \%$ das aulas.

d) sujeitos que não participaram do Pré-Teste ou do Pós-Teste.

\subsection{INSTRUMENTOS}

Como instrumento de pesquisa, foi utilizado o Teste Não Verbal de Raciocínio Infantil - TNVRI (PASQUALI, 2005). O TNVRI é composto de 58 figuras. Cada uma das figuras representam um problema, cuja solução implica que a criança possua certo nível de desenvolvimento intelectual. Todos eles implicam, como problema, a complementação de uma figura simples, ainda que composta de elementos discretos, exigindo da criança apenas a capacidade de perceber diferenças ou similaridades em cada uma, preenchendo corretamente uma lacuna simples. O TNVRI avalia basicamente dois fatores: o raciocínio analógico abstrato (Fator 1) e o raciocínio analógico concreto (Fator 2). O TNVRI produz três escores, sendo um para cada fator citado anteriormente, além do fator geral de raciocínio analógico, o qual foi o fator utilizado no presente estudo.

Figura 3 - Exemplo de figura que compõe o TNVRI

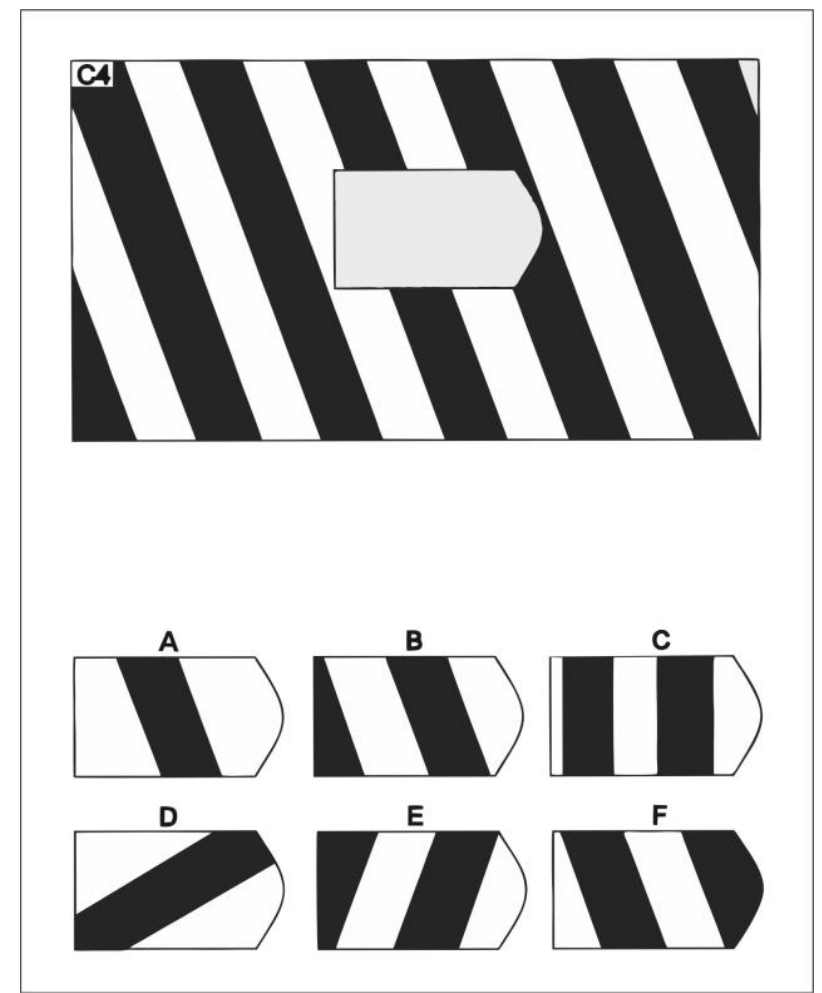

Fonte: Pasquali, 2005, p. 32. 
O TNVRI foi construído tendo como base os princípios que orientaram a criação das Matrizes Progressivas de Raven, pois, mesmo sendo um teste criado há décadas, mais precisamente em 1938, ainda existe um grande uso atualmente. Os princípios utilizados por Raven se basearam em três vertentes teóricas (PASQUALI, 2005):

a) a teoria dos dois fatores de Spearman (fator "g");

b) a teoria da Gestalt;

c) a teoria do desenvolvimento cognitivo.

O fator geral "g" de Spearman, de acordo com Pasquali (2005, p. 13), era "[...] como o fator noético, que consistia essencialmente na capacidade de fazer comparações, raciocinar por analogia e desenvolver um método lógico de pensar independentemente de informação previamente adquirida". Essa definição resume bem os processos de raciocínio lógico pelos quais um jogador de xadrez deve passar para definir qual lance, tática ou estratégia a seguir. Outro ponto que justifica a escolha desse teste diante dos inúmeros demais está no fato de ele ser um teste não verbal. Buscando evitar influências de elementos culturais e de treinamento, Raven optou por utilizar itens de caráter gráfico em vez de verbal. Além disso, um teste não verbal facilita sua aplicação em crianças as quais ainda não adquiriram plenamente a capacidade da leitura e escrita, realidade essa encontrada na escola em que o estudo foi conduzido. Um teste verbal poderia ser influenciado por esse fator, deturpando, assim, os resultados obtidos.

Pasquali (2005) afirmou que, ao construir o TNVRI, foram consideradas igualmente as ponderações de Raven quanto ao desenvolvimento cognitivo das crianças, nas quais menciona que crianças dos 5 aos 12 anos de idade passam por cinco níveis de desenvolvimento cognitivo, ao se defrontarem com a solução de problemas. Seguindo a ordem apresentada, a criança, segundo Pasquali (2005, p. 15), é capaz de:

1. Distinguir figuras idênticas de figuras diferentes e distinguir figuras similares de figuras dissimilares;

2. Avaliar a orientação da figura com relação à própria criança e a outros objetos no campo perceptual;

3. Perceber duas ou mais figuras discretas como formando um todo ou uma entidade individual organizada;

4. Analisar um todo em suas partes constituintes e distinguir entre o que aparece no real e o que ela própria acrescenta;

5. Comparar mudanças análogas nos constituintes percebidos e usar isso como um método lógico de raciocinar. 
Muitos desses "passos" de desenvolvimento se assemelham a situações encontradas em uma partida de xadrez. O item dois, por exemplo, é constantemente requisitado, pois, para movimentar uma peça no tabuleiro, bem como verificar previamente seu raio de ação antes de movimentá-la, é necessária a avaliação da orientação do objeto em relação a si mesmo, bem como ao tabuleiro e a ordenação das casas. $O$ item três também em muito se assemelha à dinâmica do jogo de xadrez, pois, mesmo sendo constituído de várias peças, 32 para ser mais exato, tais peças não devem ser vistas como figuras isoladas, mas sim como figuras formando uma entidade individual organizada. Por exemplo, dois ou mais peões unidos entre si e separados dos demais são chamados de "ilha de peões", ou seja, duas ou mais figuras discretas formando uma entidade individual organizada.

\subsection{PROCEDIMENTOS}

Foram analisados os registros de cada aluno matriculado no $2^{\circ}$ e $3^{\circ}$ anos do ensino fundamental, visando selecionar apenas crianças com idade entre 7 anos a 8 anos e 9 meses, definida como a faixa ideal para a pesquisa. Tal recorte etário justificou-se pelo Manual técnico e de aplicação, proposto por Pasquali (2005, p. 64), que observou que os escores do fator 1 e escores do fator geral crescem sistematicamente de acordo com o avanço da idade. Porém, ele afirmou que: "[...] aparecem apenas duas faixas etárias realmente distintas: 1) crianças com idade inferior a 8 ano e 9 meses e 2) crianças com idade superior a 8 anos e 9 meses". Após selecionados os alunos, foi feito o convite para participação na pesquisa. Apenas crianças que se voluntariaram a participar das aulas de xadrez e de reforço foram escolhidas.

Após a seleção dos sujeitos, foi encaminhado o TCLE para as respectivas famílias. Após o recebimento de todos os termos devidamente assinados, foi dado início à realização do pré-teste (PreT), aplicado nos dias 10 e 14 de março de 2014. O PreT seguiu todos os procedimentos recomendados pelo protocolo de aplicação do TNVRI (PASQUALI, 2005). Após a realização do PreT e obtenção dos resultados, foram iniciadas as aulas de xadrez para o GEX e de reforço para o GC1. As aulas de xadrez foram realizadas mediante metodologia e conteúdos previamente definidos (consultar Apêndice A), que buscaram ensinar as regras básicas do xadrez, tais como movimentação, captura, xeque e xeque-mate. As aulas do GC1 seguiram o 
esquema de reforço utilizado anualmente pela escola, também com metodologia e conteúdos pré-definidos pela professora da turma (consultar Apêndice B).

Após o período de 10 semanas, compreendidas entre 17 de março de 2014 e 26 de maio de 2014 (20 aulas), encerrou-se o período de intervenção tanto no GEX como no GC1. Nos dias 30 de maio e 6 de junho, foi aplicado o pós-teste (PosT). O PosT foi realizado procurando seguir exatamente a mesma forma com que o PreT foi realizado, com o mesmo instrumento, grupo de sujeitos (salvo os excluídos da pesquisa) e examinador.

\subsubsection{Aplicações do pré-teste (PreT) e do pós-teste (PosT)}

A aplicação dos testes foi realizada de forma coletiva, em datas prédeterminadas e marcadas com antecedência, respeitando a quantidade máxima de dez crianças por sessão. A escolha pela aplicação coletiva foi por conveniência, visando diminuir o tempo gasto com o PreT e também porque Pasquali (2005) recomendou a aplicação individual apenas para sujeitos abaixo dos 7 anos, o que não foi o caso do presente estudo. Sabendo que seria examinado um grupo de 36 indivíduos, com 10 crianças de cada vez por sessão de 1 h30 de duração, já podíamos inferir que seriam necessárias quatro sessões de aplicação do teste, resultando em mais de um dia de testes, tanto para o PreT como para o PosT. Dessa forma, foi seguido rigorosamente o protocolo de aplicação do teste presente no manual técnico e de aplicação do TNVRI (PASQUALI, 2005). A seguir, será descrito resumidamente o procedimento seguido na aplicação de ambos os testes (PreT e PosT).

a) o examinador foi uma pessoa externa ao estudo, ou seja, não foi o pesquisador, nem o professor que ministra as aulas, seja de reforço ou de xadrez, nem qualquer pessoa que seja do conhecimento do grupo de sujeitos. Dessa forma, evitou-se qualquer influência pela relação psíquica entre o examinador e o examinando (WEIL, 1967);

b) permaneceram na sala apenas o examinador e o grupo de examinandos, ou, apenas em dois momentos no PreT, quando o examinador julgou necessário, uma terceira pessoa foi designada para auxiliá-lo na aplicação do teste. Foi dada uma satisfação aos examinandos quanto à presença dessa terceira pessoa, dizendo-Ihes que era uma pessoa que ajudaria na 
aplicação do teste. Caso os examinandos apresentassem má vontade ou relutância, a terceira pessoa não seria utilizada para auxiliar na aplicação do teste. Porém, em nenhum momento foi necessária a retirada da terceira pessoa;

c) foi escolhida para aplicação dos testes uma sala tranquila, isolada, sem ruído ou possibilidade de interferência que pudesse desviar a atenção dos examinandos, localizada na própria escola, e que não fosse uma sala que possuísse um "significado" que pudesse trazer medo ou receio (sala da direção ou sala de aula de algum aluno). Os testes foram realizados em uma sala utilizada pelas turmas do turno matutino, ou seja, sem nenhuma ligação com os alunos do turno vespertino, que foram os constituintes do presente estudo;

d) antes da entrada das crianças, foram anotados os dados de cada uma na parte superior da folha de respostas (nome e data de nascimento), visando impedir a cópia. A distribuição dos lugares na sala se deu de forma aleatória;

e) quando as crianças adentraram a sala a ser utilizada para os testes, foiIhes informado para não abrirem os cadernos até que fosse dada ordem para fazê-lo;

f) após se apresentar para a turma, o examinador explicou a natureza e objetivo da pesquisa, também explicando que o TNVRI mede a capacidade de perceber e pensar claramente (PASQUALI, 2005);

g) finalizada a apresentação inicial, foi dada a ordem para que todos abram os cadernos na primeira página;

h) agora, mostrando uma página ampliada de exemplo que pode ser vista na figura logo a seguir, o examinador seguiu exatamente o procedimento indicado por Pasquali (2005, p. 47):

Este desenho é igual ao de vocês. Como vocês veem, na parte superior há um desenho grande com um pedaço faltando. Cada um destes pedaços embaixo (apontar para cada um deles) tem a forma correta para completar o espaço, mas nem todos completam o desenho corretamente. O pedaço "b" (apontar para o pedaço e depois para o desenho) está errado, porque mostra pernas. Os pedaços "c", "d" e "e" também estão errados, porque eles completam o espaço, mas não têm o desenho correto. O pedaço "f" está completamente errado, porque não tem nada a ver com o coelho da figura. Então fica o pedaço marcado com a letra "a" como o desenho certo (ilustrar que o desenho é o mesmo do que está acima). Assim vocês vão escrever "a" na Folha de Resposta, no quadradinho onde está escrito "Exemplo A" 
i) após observar o correto preenchimento do exemplo "a", o examinador ressaltou a necessidade do preenchimento ser feito na folha de respostas, e não no caderno. Além disso, foi citada a progressão na dificuldade de cada questão, bem como obrigatoriedade de que cada questão possuí apenas uma resposta correta;

j) preenchido corretamente o exemplo "a", os alunos foram autorizados a virarem a página e preencher o exemplo "b", dessa vez dando mais liberdade para que cada aluno a preenchesse sem auxílio prévio do examinador. Porém, assim que todos preencheram o caderno de respostas, o examinador confirmou a resposta correta, explicando os motivos pelos quais ela é a correta dentre as outras alternativas.

Figura 4 - Figura utilizada como exemplo "a" no TNVRI

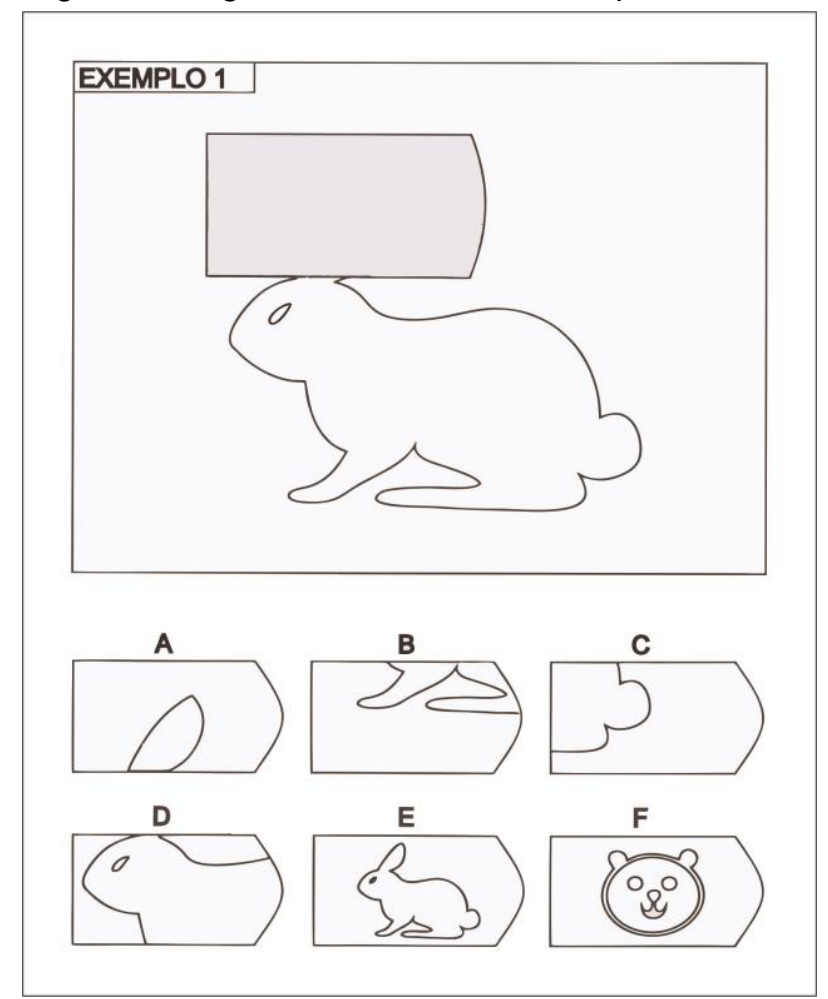

Fonte: Pasquali, 2005, p. 1.

k) após os examinandos estarem tranquilos, confiantes e em estado psíquico normal, encarando com serenidade as explicações do examinador e demonstrando naturalidade e espontaneidade, os testes foram iniciados (WEIL, 1967); 
I) o horário de início do teste foi registrado. Ao final de 15 minutos, o examinador verificou novamente se as crianças estavam registrando as respostas no local correto;

m) ao final de 20 minutos, as crianças foram instruídas a fazerem um círculo em volta do número do problema em que estavam trabalhando.

n) foi verificado, assim, que a criança terminou o teste, se a Folha de Respostas havia sido preenchida corretamente, assim como os dados de cada criança. Ao final do teste, cada criança voltou às suas atividades normais.

\subsubsection{Diferenças de gênero}

Visando responder às questões apresentadas nos objetivos específicos, alguns procedimentos adicionais foram executados durante o estudo. Para verificar possível semelhança ou diferença entre meninos e meninas, foram analisados, de forma individual, os índices obtidos por cada grupo no TNVRI. Após isso, foi feita uma análise estatística para determinar se ambos os grupos são estatisticamente iguais ou se diferenças significativas podem ser encontradas. Tal procedimento foi realizado tanto no PreT como no PosT.

\subsubsection{Pontuações no campeonato}

No que se refere à ligação entre o desempenho enxadrístico e os índices de raciocínio mensurados pelo TNVRI, foi realizado um campeonato na última semana de intervenção. O campeonato foi realizado em um único dia, englobando todos os sujeitos do grupo experimental, tanto meninos quanto meninas, e teve como objetivo classificar os sujeitos de acordo com sua expertise enxadrística. Tal campeonato foi realizado no sistema suíço, com o número de quatro rodadas de 15 minutos para cada jogador, utilizando o software Swiss Perfect para a apuração dos resultados e cálculo dos critérios de desempate. Esse sistema procura emparceirar jogadores baseando-se na pontuação obtida a cada rodada, respeitando o fato cor e retrospectos, evitando que jogadores se enfrentem mais de uma vez. Com isso, espera-se que a cada rodada jogadores do mesmo nível estejam se enfrentando, evitando disputas entre jogadores com níveis de jogos extremamente díspares. Tal 
sistema foi escolhido por poder ser executado em um curto espaço de tempo, além de ser o sistema mais utilizado nas competições de xadrez escolar atualmente, e isso também vale para a escolha de 15 minutos para cada jogador.

\subsection{ANÁLISE DOS DADOS}

Os dados coletados durante o estudo, tais como os escores obtidos no TNVRI, pontuação no campeonato e variáveis como sexo e idade foram analisados, primeiramente, de forma descritiva, a fim de evidenciar mais claramente 0 comportamento das variáveis intervenientes no estudo. Após, foram aplicados testes a fim de se rejeitar a hipótese nula, ou seja, buscando-se indicar a possível influência da prática do xadrez para o desenvolvimento do raciocínio em crianças. Os testes utilizados foram o Teste $T$ para amostras dependentes, o Teste de Wilcoxon para amostras dependentes e também a análise de variância.

\subsubsection{Análise descritiva}

A análise descritiva consiste em fazer análises a partir da sumarização e da organização de dados. As principais medidas calculadas são: primeiro, segundo e terceiro quartis, média, variância, mínimo e máximo.

Para calcular os quartis, é necessário primeiro ordenar os dados. O primeiro quartil $\left(Q_{1}\right)$, segundo quartil $\left(Q_{2}\right)$ e terceiro quartil $\left(Q_{3}\right)$ são obtidos da seguinte forma:

$$
\begin{aligned}
& \mathrm{Q}_{1}=\mathrm{X}_{\mathrm{n} / 4} \\
& \mathrm{Q}_{2}=\mathrm{X}_{\mathrm{n} / 2} \\
& \mathrm{Q}_{3}=\mathrm{X}_{3 \mathrm{n} / 4}
\end{aligned}
$$

Onde n é o número de observações. O segundo quartil também é conhecido como mediana.

A Média é obtida por:

A Variância e Desvio Padrãó: $\bar{x}=\frac{\sum_{\mathrm{i}=1}^{\mathrm{n}} \mathrm{x}_{\mathrm{i}}}{\mathrm{n}}$

$$
\operatorname{Var}(\mathrm{X})=\frac{\sum_{\mathrm{i}=1}^{\mathrm{n}}\left(\mathrm{X}_{\mathrm{i}}-\overline{\mathrm{x}}\right)^{2}}{\mathrm{n}-1}
$$


O Coeficiente de Variação, que é usado para comparar variâncias de grupos diferentes, é dado por:

$$
\mathrm{CV}(\mathrm{X})=\frac{\sqrt{\operatorname{Var}(\mathrm{X})}}{\overline{\mathrm{x}}}
$$

Para se obter o Mínimo e o Máximo, basta ordenar os dados. O menor valor será o Mínimo e o maior valor será o Máximo.

Para melhor análise descritiva dos dados, foi utilizado o gráfico boxplot, que é um tipo de gráfico no qual se pode perceber de forma mais clara como os dados estão distribuídos (BUSSAB; MORETTIN, 2010).

Observe a ilustração desse gráfico a seguir:

Gráfico 1 - Gráfico ilustrativo do comportamento de um bloxplot

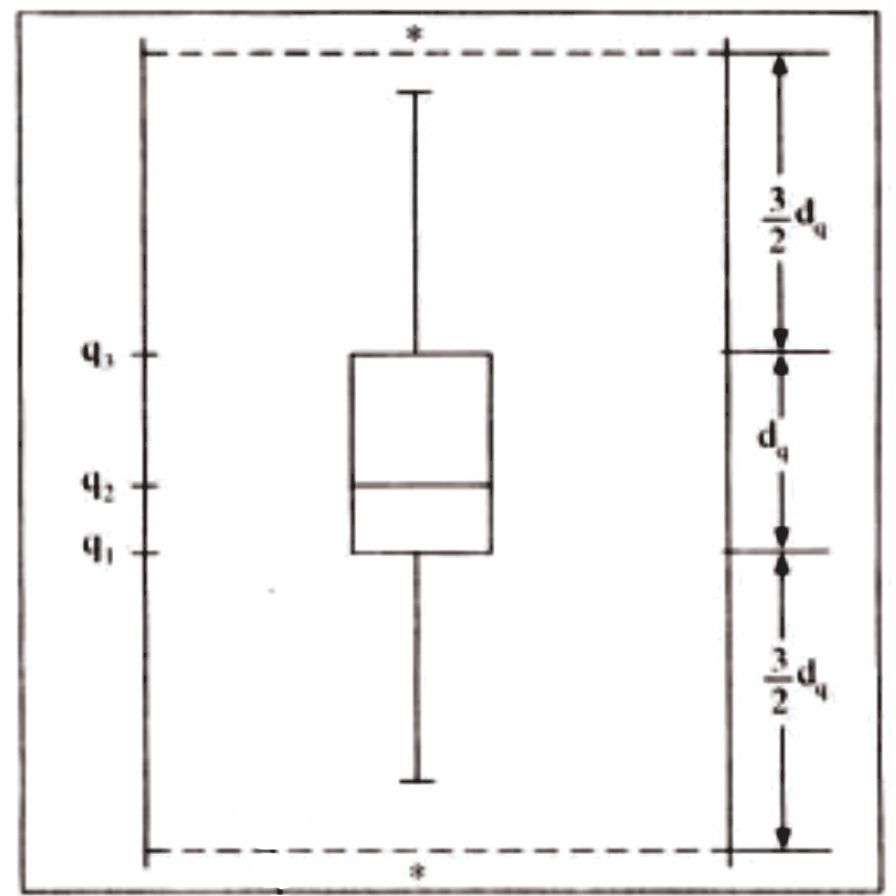

Fonte: BUSSAB; MORETTIN, 2010, p. 48.

Para fazer um gráfico do tipo boxplot, é necessário primeiramente ordenar os dados de forma crescente. Os traços inferior e superior representam, respectivamente, o valor mínimo e máximo dos dados. A porção inferior do retângulo principal diz respeito ao segundo quartil (ou seja, a porção que mostra o agrupamento de $25 \%$ dos dados); já a porção superior do retângulo mostra o terceiro quartil (ou seja, a porção que denota o agrupamento de $75 \%$ dos dados). 0 traço no interior do retângulo representa a mediana do conjunto de dados, ou seja, o 
valor em que o conjunto de dados é dividido em dois subconjuntos de mesmo tamanho. Os valores representados por asteriscos são outliers. Os outliers são valores discrepantes da série de dados, valores que não demonstram a realidade de um conjunto de dados (MONTGOMERY, 2001).

\subsubsection{Teste de hipótese}

Teste de hipótese é uma técnica estatística em que se testa uma afirmação sobre determinada característica da população. O teste de hipótese é composto pela hipótese nula $\left(\mathrm{H}_{0}\right)$ e hipótese alternativa $\left(\mathrm{H}_{1}\right)$. A hipótese nula é formulada a partir do conhecimento prévio que se tem sobre a população estudada, ou seja, sobre a distribuição de probabilidade do parâmetro. Já a hipótese alternativa é aquela que se pretende testar. A rejeição ou não da hipótese nula é baseada em uma estatística obtida a partir da amostra. Em um nível mais geral:

$$
\begin{aligned}
& \mathrm{H}_{0}: \theta=\theta_{0} \\
& \mathrm{H}_{1}: \theta \neq \theta_{0}
\end{aligned}
$$

Poderíamos, ainda, ter alternativas da forma, dependendo do que é desejado.

$$
\mathrm{H}_{1}: \theta<\theta_{0} \text { ou } \mathrm{H}_{1}: \theta>\theta_{0},
$$

Para que a decisão seja tomada, necessita-se de uma estatística teste (função relacionada ao que se deseja testar baseada nos valores amostrais) e da construção da região crítica. A região crítica é composta pelos valores para os quais a hipótese nula é rejeitada, ou seja, caso a estatística teste retorne um valor que está dentro da região crítica, rejeita-se a hipótese nula (MONTGOMERY, 2001). Outra forma para a tomada de decisão é o chamado p-valor, que é a probabilidade de se observar valor mais extremo que o observado na amostra. Se o p-valor for menor que o nível de significância, a hipótese nula é rejeitada. $\mathrm{O}$ valor $\alpha$ recebe o nome de nível de significância. Esse valor é a probabilidade de se rejeitar a hipótese $\mathrm{H}_{0}$, dado que ela é verdadeira. Bussab e Morettin afirmaram que:

\footnotetext{
$\mathrm{O}$ resultado da amostra é tanto mais significante para rejeitar $\mathrm{H}_{0}$ quanto menor for esse nível. Ou seja, quanto menor for $\alpha$, menor é a probabilidade de se obter uma amostra com estatística pertencente à região crítica, sendo pouco verossímil a obtenção de uma amostra da população para a qual $\mathrm{H}_{0}$ seja verdadeira. Usualmente, o valor de $\alpha$ é fixado em $5 \%, 1 \%$ ou $0,1 \%$.
}

No presente estudo, o nível de significância utilizado foi de 5\%. 
3.8.2.1 Teste $\mathrm{T}$ para amostras dependentes

Considere duas amostras dependentes $X_{1}, \ldots, X_{n}$ e $Y_{1}, \ldots, Y_{n}$, onde as observações são pareadas, ou seja, $\left(X_{1}, Y_{n}\right), \ldots,\left(X_{n}, Y_{n}\right)$. Seja $D_{i}=X_{i}-Y_{i}$, para $i=1$, ..., n. Então, a amostra $D_{1}, \ldots, D_{n}$ é obtida a partir das diferenças entre os valores de cada par. A suposição é de que a população das diferenças segue distribuição Normal com média $\mu_{\mathrm{D}}$ e variância $\sigma^{\mathrm{D}_{2}}$.

As hipóteses:

$$
\begin{aligned}
& H_{0}: \mu_{D}=0 . \\
& H_{1}: \mu_{D} \neq 0 .
\end{aligned}
$$

onde $\mu_{D}=\mu_{1}-\mu_{2}$, sendo $\mu_{1}$ e $\mu_{2}$ as médias correspondentes às populações de $X$ e $\mathrm{Y}$, respectivamente.

$\mathrm{Ou}$ :

$\mathrm{H}_{0}$ : A média das diferenças é igual a zero.

$\mathrm{H}_{1}$ : A média das diferenças é diferente de zero.

A formulação das hipóteses varia conforme o que é desejado. Os parâmetros $\mu \mathrm{D}$ e $\sigma_{\mathrm{D}}^{2}$ são estimados pela média e variância amostrais:

$$
\begin{gathered}
\bar{D}=\frac{1}{n} \sum_{i=1}^{n} D_{i} \\
S_{D}^{2}=\frac{1}{n-1} \sum_{i=1}^{n}\left(D_{i}-\bar{D}\right)^{2}
\end{gathered}
$$

A estatística $\bar{D}$ tem distribuição Normal com média $\mu_{D}$ e variância $\frac{\sigma_{D}^{2}}{n}$.

A estatística do teste terá distribuição $t$ de Student, com $(n-1)$ graus de liberdade - número de observações ou de grupos menos o número de estimativas calculadas a partir da amostra:

$$
\mathrm{T}=\frac{\sqrt{\mathrm{n}}\left(\overline{\mathrm{D}}-\mu_{\mathrm{D}}\right)}{\mathrm{S}_{\mathrm{D}}}
$$

Caso o p-valor seja menor que o nível de significância considerado, a hipótese nula é rejeitada. 


\subsubsection{Teste de Wilcoxon para amostras dependentes}

O teste de Wilcoxon é um teste não paramétrico que tem o objetivo de verificar se duas amostras aleatórias $X$ e $Y$ possuem a mesma função de distribuição. Em função disso, esse teste também pode ser utilizado para a comparação de médias entre amostras dependentes. Seja $D_{i}=X_{i}-Y_{i}$, para $i=1, \ldots$, n. Então, a amostra $D_{1}, \ldots, D_{n}$ é obtida a partir das diferenças entre os valores de cada par. As hipóteses deste teste são:

$$
\begin{gathered}
H_{0}: \mu_{x}-\mu_{y}=\mu_{D}=0 \\
H_{1}: \mu_{x} \neq \mu_{y} \neq 0 \text { ou } H 1: \mu_{x}>\mu_{y} \text { ou } H 1: \mu_{x}<\mu_{y}
\end{gathered}
$$

Em que:

$$
\begin{aligned}
& \mu_{\mathrm{x}}=\text { média populacional de } \mathrm{X} \\
& \mu_{\mathrm{y}}=\text { média populacional de } \mathrm{Y}
\end{aligned}
$$

O teste é feito a partir da ordenação da variável $D_{i}$ e postos (ou ranks) são atribuídos a cada observação. Após essa ordenação, algumas observações podem receber a mesma posição na ordenação. Esse fenômeno é denominado empate. A estatística do teste é calculada da seguinte maneira:

Considere:

$$
R_{i}=\left\{\begin{array}{rr}
R\left(X_{i}, Y_{i}\right), & \text { se } D_{i}>0, \\
-R\left(X_{i}, Y_{i}\right), & \text { se } D_{i}<0,
\end{array}\right.
$$

Onde $R\left(X_{i}, Y_{i}\right)$ é o posto associado a $\left(X_{i}, Y_{i}\right)$.

Se não houver empates, a estatística a ser usada é:

$$
\mathrm{T}^{+}=\sum\left(\mathrm{R}_{\mathrm{i}} \operatorname{com} \mathrm{D}_{\mathrm{i}}>0\right),
$$

Ou seja, a soma dos postos positivos.

Se houver empates, a estatística a ser usada tem distribuição normal com média zero e variância 1 e é dada por:

$$
\mathrm{V}=\frac{\sum_{\mathrm{i}=1}^{\mathrm{n}} \mathrm{R}_{\mathrm{i}}}{\sqrt{\sum_{\mathrm{i}=1}^{\mathrm{n}} \mathrm{R}_{\mathrm{i}}^{2}}}
$$

Caso o p-valor seja menor que o nível de significância, a hipótese nula é rejeitada (BUSSAB; MORETTIN, 2010). 


\subsubsection{Análise de Variância}

A Análise de Variância, mais conhecida por ANOVA, consiste em um teste de hipótese, em que é testado se as médias dos tratamentos (ou grupos) são iguais. Os dados são descritos pelo seguinte modelo:

$$
\mathrm{y}_{i j}=\mu+\mathrm{a}_{i}+e_{i j}, \mathrm{i}=1, \ldots, \mathrm{a} \text { e } \mathrm{j}=1, \ldots, \mathrm{N},
$$

em que, i é o número de tratamentos, j o número de observações e yij a j-ésima observação do i-ésimo tratamento.

No modelo, $\mu$ é a média geral dos dados e $\alpha_{i}$ é o efeito do tratamento i na variável resposta. Já $e_{i j}$ é a variável aleatória correspondente ao erro. Supõe-se que tal variável tem distribuição de probabilidade Normal com média zero e variância $\sigma^{2}$. Mais precisamente, $e_{i j} \sim N\left(0, \sigma^{2}\right)$.

A variabilidade total pode ser decomposta na variabilidade devido aos diferentes tratamentos, somada à variabilidade dentro de cada tratamento:

Soma de Quadrados Total (SQtotal) =

Soma de Quadrados de Tratamento (SQtrat) + Soma de Quadrados de

Resíduos (SQres).

Sendo o estudo balanceado, ou seja, os tratamentos possuem tamanhos de amostra iguais:

$$
\begin{gathered}
\mathrm{SQ}_{\text {total }}=\sum_{\mathrm{i}=1}^{\mathrm{a}} \sum_{\mathrm{j}=1}^{\mathrm{n}_{\mathrm{i}}} \mathrm{y}_{\mathrm{ij}}^{2}-\frac{\mathrm{y}_{\mathrm{w}}^{2}}{\mathrm{~N}} \\
\mathrm{SQ}_{\text {trat }}=\sum_{\mathrm{i}=1}^{\mathrm{a}} \frac{\mathrm{y}_{\mathrm{i}}^{2}}{\mathrm{n}_{\mathrm{i}}}-\frac{\mathrm{y}_{\mathrm{s}}^{2}}{\mathrm{~N}} \\
\mathrm{SQ}_{\text {res }}=\sum_{\mathrm{i}=1}^{\mathrm{a}} \sum_{\mathrm{j}=1}^{\mathrm{n}_{\mathrm{i}}} \mathrm{y}_{\mathrm{ij}}^{2}-\sum_{\mathrm{i}=1}^{\mathrm{a}} \frac{\mathrm{y}_{\mathrm{i}}^{2}}{\mathrm{n}_{\mathrm{i}}}
\end{gathered}
$$

onde $\mathrm{n}_{\mathrm{i}}$ é o número de observações do í-ésimo tratamento, $\mathrm{N}$ o número total de observações e

$$
\begin{gathered}
y_{-}=\sum_{i=1}^{a} \sum_{j=1}^{n_{i}} y_{i j} \\
y_{i s}=\sum_{j=1}^{n_{i}} y_{i j}
\end{gathered}
$$


As hipóteses do teste são:

$$
\begin{gathered}
\mathrm{H}_{0}: \mu_{1}=\mu_{2}=\cdots=\mu_{\mathrm{a}}=\mu \\
\mathrm{H}_{1}: \exists \mu_{\mathrm{k}} \neq \mu_{1}
\end{gathered}
$$

Ou:

$$
\mathrm{H}_{0} \text { : As médias dos a tratamentos são iguais. }
$$

$\mathrm{H}_{1}$ : Existe pelo menos um par de médias diferente.

A estatística do teste é composta pelo Quadrado Médio de Tratamento (QMTRAT) e Quadrado Médio de Resíduos (QMRES), sendo a definição de Quadrado Médio a divisão da Soma de Quadrados por seus graus de liberdade. Por conta da suposição de Normalidade dos erros no modelo, a estatística do teste, F, tem distribuição $F$ de Snedecor com $(a-1)$ e $\left(\sum_{i=1}^{a} n_{i}-a\right)$ graus de liberdade.

$$
\mathrm{F}=\frac{\frac{\mathrm{SQ}}{(\mathrm{a}-1)}}{\frac{\mathrm{SQ}_{\text {res }}}{\left(\sum_{\mathrm{i}=1}^{\mathrm{a}} \mathrm{n}_{\mathrm{i}}-\mathrm{a}\right)}}
$$

A hipótese nula é rejeitada caso o p-valor seja menor que o nível de significância pré-fixado. No presente estudo, o valor pré-fixado do nível de significância é de $5 \%$ ou $p<0,05$. Dessa forma, o valor apresentado terá um intervalo

\begin{tabular}{|c|c|c|c|c|}
\hline Source of Variation & $\begin{array}{l}\text { Sum of } \\
\text { Squares }\end{array}$ & $\begin{array}{l}\text { Degrees of } \\
\text { Freedom }\end{array}$ & $\begin{array}{l}\text { Mean } \\
\text { Square }\end{array}$ & $F_{0}$ \\
\hline & $S S_{\text {Treadments }}$ & & & \\
\hline Between treatments & $=n \sum_{i=1}^{a}\left(\bar{y}_{L}-\bar{y}\right)^{2}$ & $a-1$ & $M S_{\text {Treatments }}$ & $F_{0}=\frac{M S_{\text {Treatments }}}{M S_{E}}$ \\
\hline Error (within treatments) & $S S_{E}=S S_{T}-S S_{\text {Treatments }}$ & $N-a$ & $M S_{E}$ & \\
\hline Total & $S S_{\mathrm{T}}=\sum_{i=1}^{a} \sum_{j=1}^{n}\left(y_{l}-\bar{y} . .\right)^{2}$ & $N-1$ & & \\
\hline
\end{tabular}
de confiança de $95 \%$. A tabela a seguir resume melhor as informações anteriores, deixando de forma mais clara os dados para facilitar a compreensão:

Tabela 3 - Tabela da Análise de Variância

Fonte: MONTGOMERY, 2001, p. 75. 


\section{RESULTADOS}

\subsection{ANÁLISE DESCRITIVA}

A análise exploratória dos dados se inicia com um breve estudo sobre a variável Sexo:

Tabela 4 - Frequências e porcentagens da variável sexo

\begin{tabular}{ccc}
\hline Sexo & Frequência & Porcentagem \\
\hline Feminino & 18 & $50,0 \%$ \\
Masculino & 18 & $50,0 \%$ \\
\hline TOTAL & $\mathbf{3 6}$ & $\mathbf{1 0 0 , 0 0 \%}$ \\
\hline
\end{tabular}

Fonte: Elaborado a partir dos dados obtidos no teste.

Vemos que a amostra está perfeitamente balanceada, apresentando o mesmo número de sujeitos do sexo masculino como do sexo feminino. Porém, as amostras não foram balanceadas quando analisamos cada grupo individualmente, pois a quantidade de meninos e meninas varia em cada grupo, como podemos ver no gráfico abaixo:

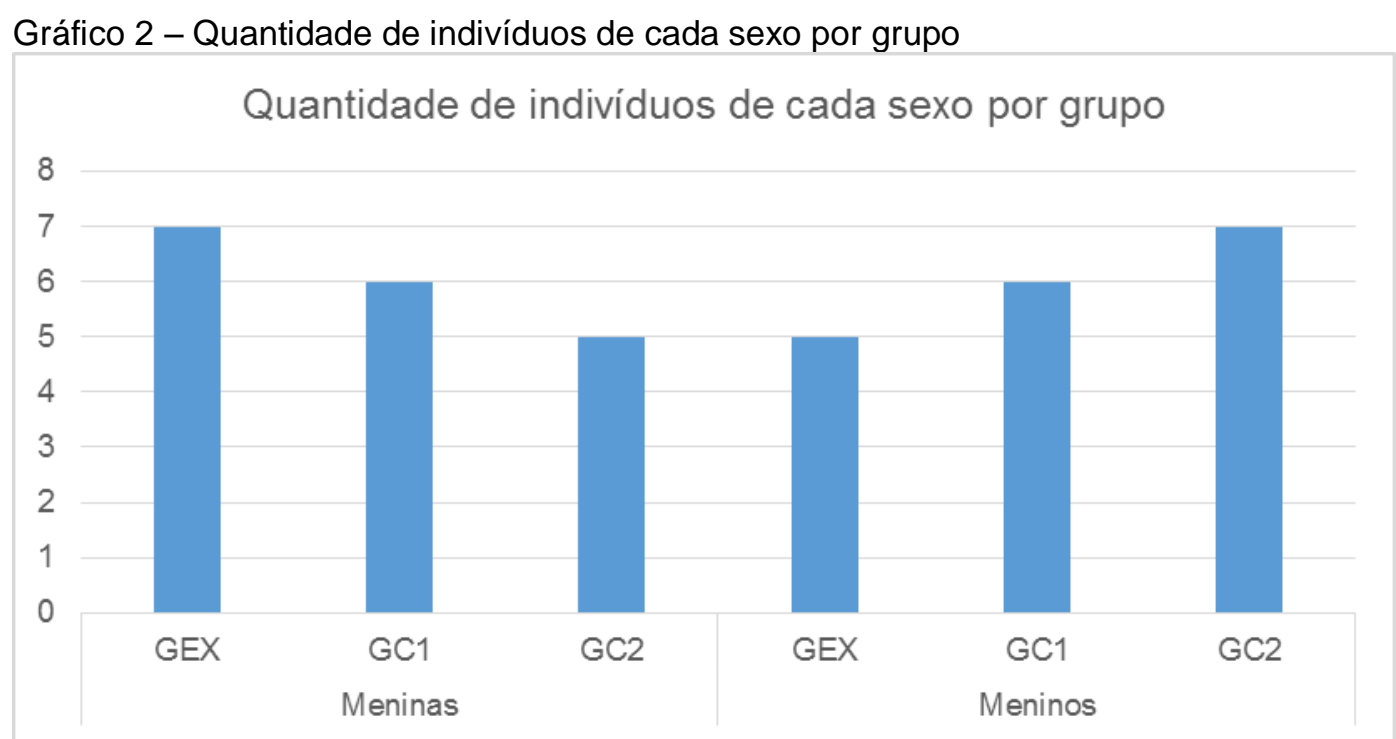

Fonte: Elaborado a partir dos dados obtidos no teste.

Adiante vemos a tabela que exibe as frequências e porcentagens relacionadas à variável atividade, ou seja, quantos alunos compunham o GEX (que 
frequentou aulas de xadrez), GC1 (que frequentou aulas de reforço) e GC2 (que não frequentou nenhuma aula extra):

Tabela 5 - Frequências e porcentagens da variável grupo

\begin{tabular}{ccc}
\hline Grupo & Frequência & Porcentagem \\
\hline GEX & 12 & $33,33 \%$ \\
GC1 & 12 & $33,33 \%$ \\
GC2 & 12 & $33,33 \%$ \\
\hline TOTAL & $\mathbf{3 6}$ & $\mathbf{1 0 0 , 0 0 \%}$ \\
\hline
\end{tabular}

Fonte: Elaborado a partir dos dados obtidos no teste.

A quantidade de indivíduos por grupo foi decidida por conveniência, devido ao tamanho da sala e das turmas presentes na escola onde o estudo foi conduzido. Outro motivo reside na maior facilidade com que, em um grupo reduzido, é possível dar suporte e conduzir um processo de ensino-aprendizagem em xadrez. Cabe ressaltar que, inicialmente, a amostra era composta por 25 indivíduos em cada grupo. Porém, devido à realidade rural da escola onde o estudo foi conduzido, é comum a grande rotatividade de alunos durante o ano letivo, devido às épocas de plantio e colheita. Sendo assim, indivíduos que participaram do PreT e não puderam participar do PosT foram, por motivos óbvios, excluídos da pesquisa. Outros três sujeitos foram excluídos do GEX com o objetivo de homogeneizar a amostra, tanto em número de indivíduos como pelo equilíbrio entre os sexos masculino e feminino.

Para que os resultados sejam mais bem examinados, o Fator Geral PreT e Fator Geral PosT serão vistos separadamente mais adiante. Primeiramente, por questão de curiosidade, vamos ver como se comportaram os dados do Fator 1 (raciocínio analógico abstrato) e do Fator 2 (raciocínio analógico concreto), que não são objeto principal deste estudo, mas que contribuem para entender os resultados do Fator Geral. O Fator 1 PreT e o Fator 2 PreT equivalem ao momento em que as turmas ainda não tinham praticado sua atividade correspondente, e o Fator 1 PosT e Fator 2 PosT, ao momento posterior à prática da atividade. O Fator 2 possui menor amplitude em ambos os momentos, assim como o primeiro, segundo e terceiro quartis praticamente não se alteram. Considere a tabela a seguir, com as estatísticas descritivas para o Fator 1 e 2 PreT e Fator 1 e 2 PosT, referente a toda a amostra, ou seja, os dados dos três grupos (GEX, GC1 e GC2): 
Tabela 6 - Principais estatísticas descritivas para o Fator 1 e 2 PreT e o Fator 1 e 2 PosT

\begin{tabular}{|c|c|c|c|c|}
\hline \multirow{2}{*}{ Estatística } & \multicolumn{4}{|c}{ Fator } \\
\cline { 2 - 5 } & $\begin{array}{c}\text { Fator 1 } \\
\text { PreT }\end{array}$ & $\begin{array}{c}\text { Fator 2 } \\
\text { PreT }\end{array}$ & $\begin{array}{c}\text { Fator 1 } \\
\text { PosT }\end{array}$ & $\begin{array}{c}\text { Fator 2 } \\
\text { PosT }\end{array}$ \\
\hline Mínimo & 3,00 & 1,00 & 3,00 & 0,00 \\
\hline 1ㅇ Quartil & 8,00 & 11,00 & 12,75 & 12,00 \\
\hline Mediana & 14,50 & 13,00 & 19,5 & 13,00 \\
\hline Média & 15,22 & 10,78 & 18,39 & 11,53 \\
\hline 3o Quartil & 22,25 & 13,00 & 24,25 & 13,00 \\
\hline Máximo & 33,00 & 13,00 & 34,00 & 13,00 \\
\hline Variância & 68,75 & 15,15 & 58,24 & 11,17 \\
Coeficiente de & $54,47 \%$ & $36,11 \%$ & $41,50 \%$ & $28,99 \%$ \\
\hline Variação & & & & \\
\hline
\end{tabular}

Fonte: Elaborado a partir dos dados obtidos no teste.

Isso mostra que o raciocínio analógico concreto, no geral, pouco se alterou entre o PreT e o PosT. O Fator 2 PosT possui a menor taxa de variação dentre os fatores estudados, ou seja, a dispersão dos dados em relação à média no PosT ocorre a uma taxa de $28,99 \%$. Para melhor visualização, podemos acompanhar no gráfico a seguir, que retrata apenas a realidade do GC1, como foi pequena a variação entre o PreT e o PosT, bem como foi pequena a taxa variação no que se refere ao Fator 2:

Gráfico 3 - Comparação de resultados PreT e PosT - Fator 2 - GC1 Comparação de escores PreT e PosT - Fator 2 - GC1

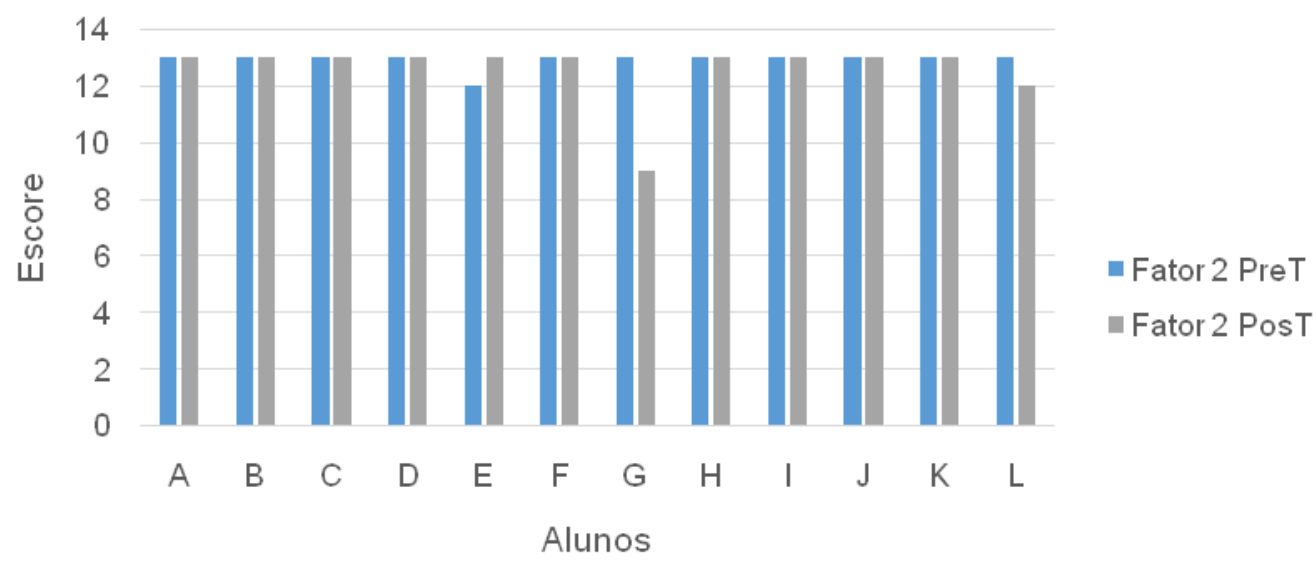

Fonte: Elaborado a partir dos dados obtidos no teste. 
No Fator 1, foi possível observar o mesmo comportamento, com amplitudes menores e quartis semelhantes. Porém, a média e mediana de ambos os momentos apresentaram maior variação. Se no PosT do Fator 2 o Coeficiente de variação foi de 28,99\%, no Fator 1 esse mesmo coeficiente foi de 41,50\%. No gráfico 3, é possível observar facilmente essa maior variação, se comparado ao gráfico anterior que retrata as variações de escore do Fator 2 no GC1 entre o PreT e o PosT, o qual apresentou um coeficiente de variação menor (12,51\% de diferença).

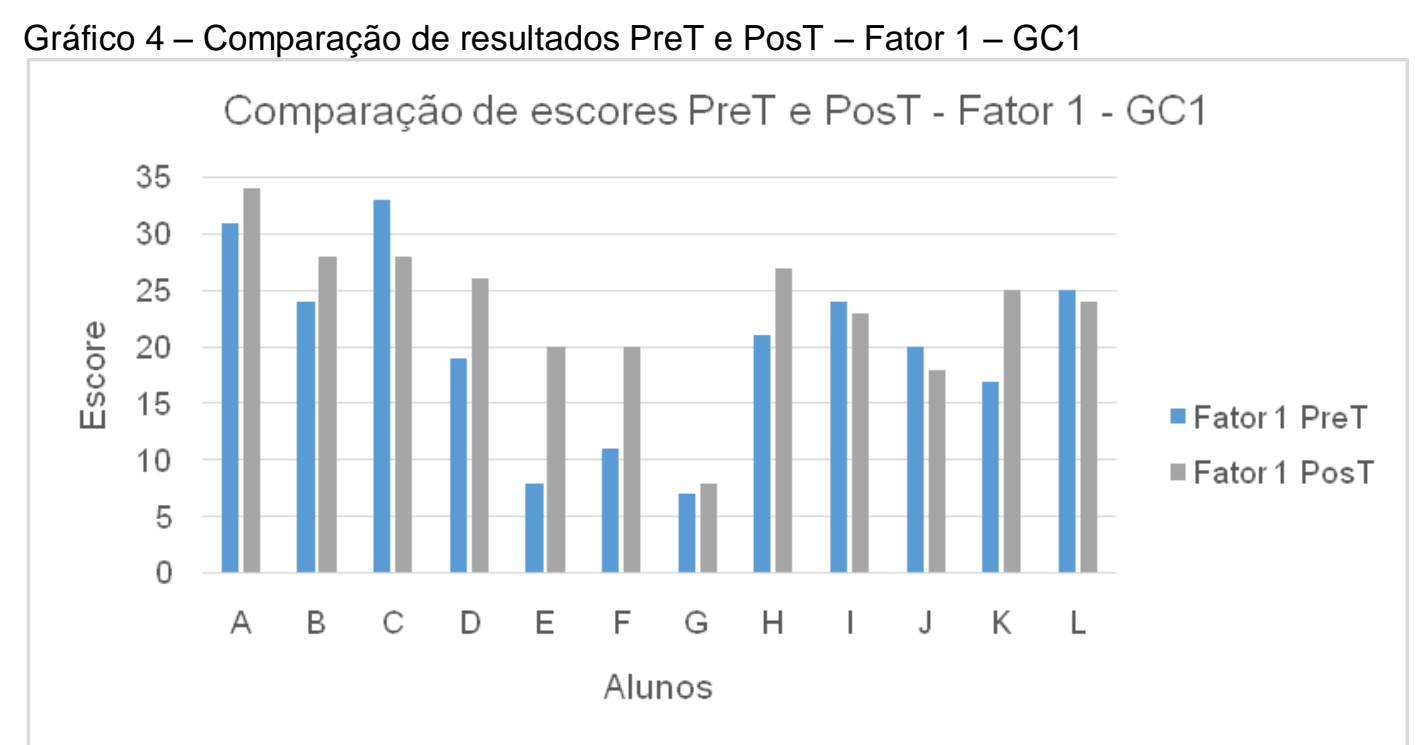

Fonte: Elaborado a partir dos dados obtidos no teste.

Após observarmos esses dados mais detalhados dos fatores 1 e 2, vamos ao Fator Geral, que é o principal fator a ser levado em consideração no presente estudo.

Gráfico 5 - Boxplot do Fator Geral PreT por grupo

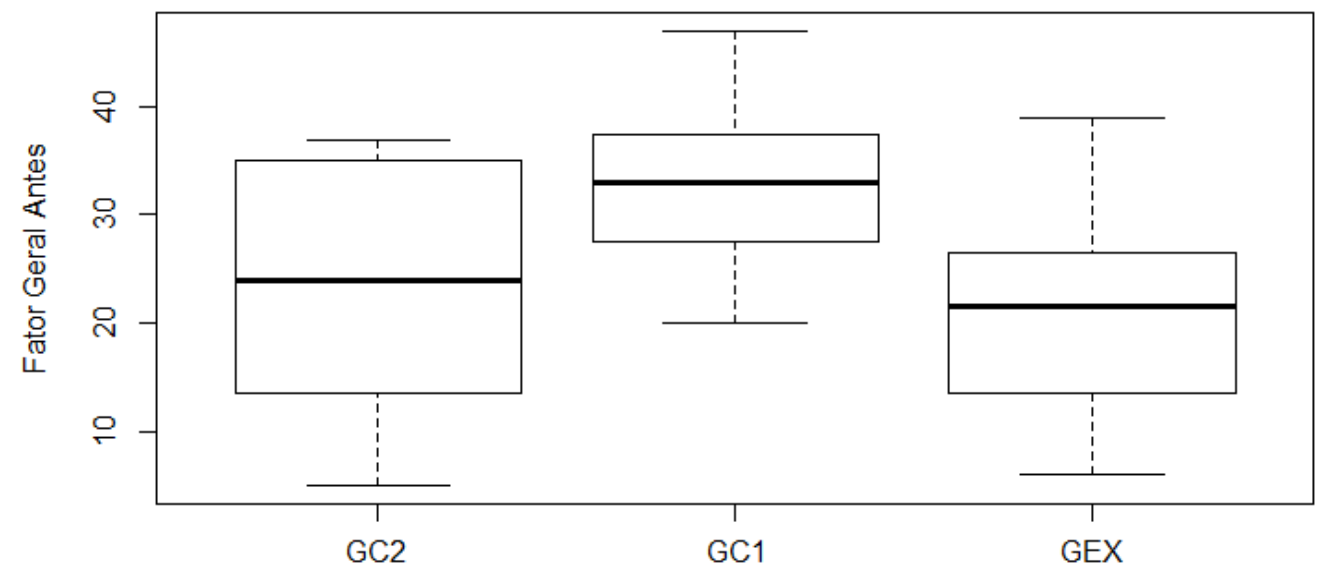

Fonte: Elaborado a partir dos dados obtidos no teste. 
No boxplot anterior, podemos ver graficamente a distribuição dos escores do Fator Geral no PreT, divididos por grupo. Assim, é possível verificar a proximidade entre as medianas dos grupos GEX e GC2, denotando, assim, certa semelhança entre os grupos, mesmo que os Quartis e Coeficiente de Variação sejam diferentes. A variabilidade dos escores também pode ser analisada: os escores do grupo GC2 são mais dispersos (pois é o grupo que apresenta os maiores Coeficientes de Variação, 51,52\% no PreT e 45,20\% no PosT) em relação à média quando comparados com os demais grupos. Também podemos ver que o GEX é o grupo com menor mediana em comparação aos demais grupos no PreT. Em relação aos escores, o GC1 é o que apresenta os maiores escores em todas as medidas estatísticas visualizadas no boxplot (quartis, média, mediana, máximo e mínimo), seguido pelo GC2 e GEX, respectivamente. Isso mostra que o GC1 inicia o estudo com índices de raciocínio maiores que os demais. Porém, apenas o GC1 se destaca, pois o GEX e GC2, por mais que difiram em alguns dados, se mostram semelhantes.

Agora temos a visualização gráfica do Fator Geral PosT, por grupo:

Gráfico 6 - Boxplot do Fator Geral PosT por grupo

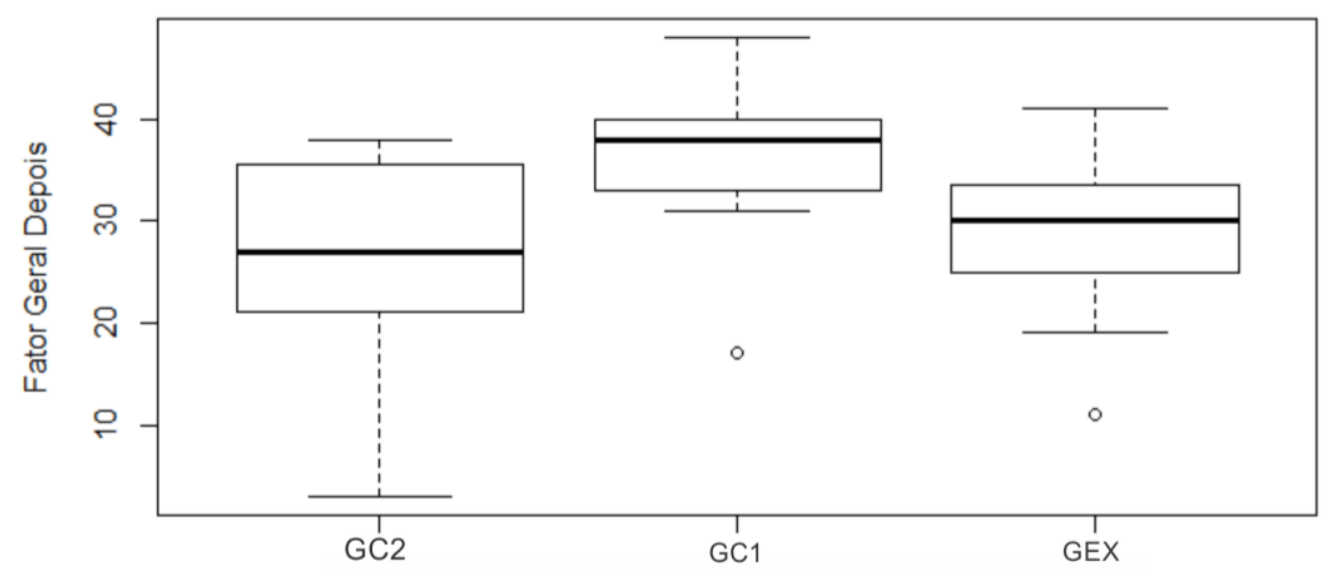

Fonte: Elaborado a partir dos dados obtidos no teste.

Quando comparado às demais atividades, o Fator Geral PosT do GC1 é o que apresenta menor Coeficiente de Variação e, sendo assim, menor dispersão dos dados em relação à média. Os quartis das atividades já não estão tão próximos quanto no boxplot anterior, referente ao PreT. Isso mostra que as atividades desempenhadas em cada grupo (ou a ausência delas, como no caso do GC2) 
tendem a homogeneizar a amostra, ou seja, os indivíduos passam a obter escores mais aproximados da média geral do grupo.

Entretanto, a tabela a seguir organiza os dados obtidos de forma objetiva, a fim de verificar os valores encontrados nos Quartis, médias, medianas e Coeficientes de Variação de forma mais clara, permitindo-nos analisar profundamente as variações nos escores entre os grupos.

Tabela 7 - Principais estatísticas descritivas para o Fator Geral PreT e Fator Geral PosT por grupo

\begin{tabular}{|c|c|c|c|c|c|c|}
\hline \multirow{3}{*}{ Estatística } & \multicolumn{6}{|c|}{ Fator } \\
\hline & \multicolumn{2}{|c|}{ GEX } & \multicolumn{2}{|c|}{ GC1 } & \multicolumn{2}{|c|}{ GC2 } \\
\hline & $\begin{array}{l}\text { Fator } \\
\text { Geral } \\
\text { PreT }\end{array}$ & $\begin{array}{l}\text { Fator } \\
\text { Geral } \\
\text { PosT }\end{array}$ & $\begin{array}{l}\text { Fator } \\
\text { Geral } \\
\text { PreT }\end{array}$ & $\begin{array}{l}\text { Fator } \\
\text { Geral } \\
\text { PosT }\end{array}$ & $\begin{array}{l}\text { Fator } \\
\text { Geral } \\
\text { PreT }\end{array}$ & $\begin{array}{l}\text { Fator } \\
\text { Geral } \\
\text { PosT }\end{array}$ \\
\hline Mínimo & 6,00 & 11,00 & 20,00 & 17,00 & 5,00 & 3,00 \\
\hline $1^{\circ}$ Quartil & 13,50 & 25,00 & 27,50 & 33,00 & 13,50 & 21,00 \\
\hline Mediana & 21,50 & 30,00 & 33,00 & 38,00 & 24,00 & 27,00 \\
\hline Média & 20,83 & 28,50 & 33,00 & 36,33 & 23,25 & 25,33 \\
\hline 3 Quartil & 26,50 & 33,50 & 37,50 & 40,00 & 35,00 & 35,50 \\
\hline Máximo & 39,00 & 41,00 & 47,00 & 48,00 & 37,00 & 38,00 \\
\hline Desv.Pad. & 9,71 & 7,96 & 8,35 & 7,59 & 11,98 & 11,45 \\
\hline C.V. & $46,61 \%$ & $27,92 \%$ & $25,30 \%$ & $20,89 \%$ & $51,52 \%$ & $45,20 \%$ \\
\hline
\end{tabular}

Fonte: Elaborado a partir dos dados obtidos no teste.

Na Tabela 7, a análise do Fator Geral PreT e Fator Geral PosT está dividida por grupos. Podemos observar de início que o escore médio obtido no Fator Geral PosT é maior que o do Fator Geral PreT em relação a todos os grupos. Porém, é possível observar que a diferença entre o escore obtido no PosT em relação ao PreT é maior no GEX do que no GC1 e GC2. O ganho médio no GEX foi de 7,67 pontos. Já no GC1 e GC2 foi de 3,33 e 2,08, respectivamente. Para melhor análise, a título de comparação, podemos ver a seguir as diferenças de ganhos entre os três grupos. 
Tabela 8 - Comparação de ganhos entre os grupos

\begin{tabular}{cccc}
\hline \multicolumn{2}{c}{ Comparação } & $\begin{array}{c}\text { Diferença de } \\
\text { ganhos }\end{array}$ & \% de diferença \\
\hline GEX & GC1 & $+4,34$ & $130,33 \%$ \\
GEX & GC2 & $+5,59$ & $268,75 \%$ \\
GC1 & GC2 & $+1,25$ & $60,10 \%$ \\
\hline
\end{tabular}

Fonte: Elaborado a partir dos dados obtidos no teste.

Podemos ver que o GEX obteve um ganho 130,33\% superior ao GC1 e $268,75 \%$ superior ao GC2. O GC1 obteve ganhos $60,10 \%$ superiores que o GC2. Isso mostra o quanto o grupo que frequentou as aulas de xadrez avançou durante o período experimental, sugerindo assim um ganho superior aos demais. A maior diferença encontrada foi entre o GEX e o GC2, pois os ganhos obtidos no GEX foram três vezes maiores que os encontrados no GC2. A menor diferença de ganhos encontrada foi entre o GC1 e o GC2, já que a diferença, em pontos, foi de apenas 1,25 entre ambos os grupos.

\subsection{ANÁLISE DE VARIÂNCIA DA DIFERENÇA ENTRE O FATOR GERAL ANTES E O FATOR GERAL DEPOIS}

Para verificar se as médias da diferença entre o Fator Geral Antes e Fator Geral Depois do GEX, GC1 e GC2 diferem, foram feitos o boxplot para visualização gráfica dos dados e, em seguida, a Análise de Variância.

\section{Gráfico 7 - Boxplot da diferença entre o Fator Geral Antes e Fator Geral Depois por grupo}

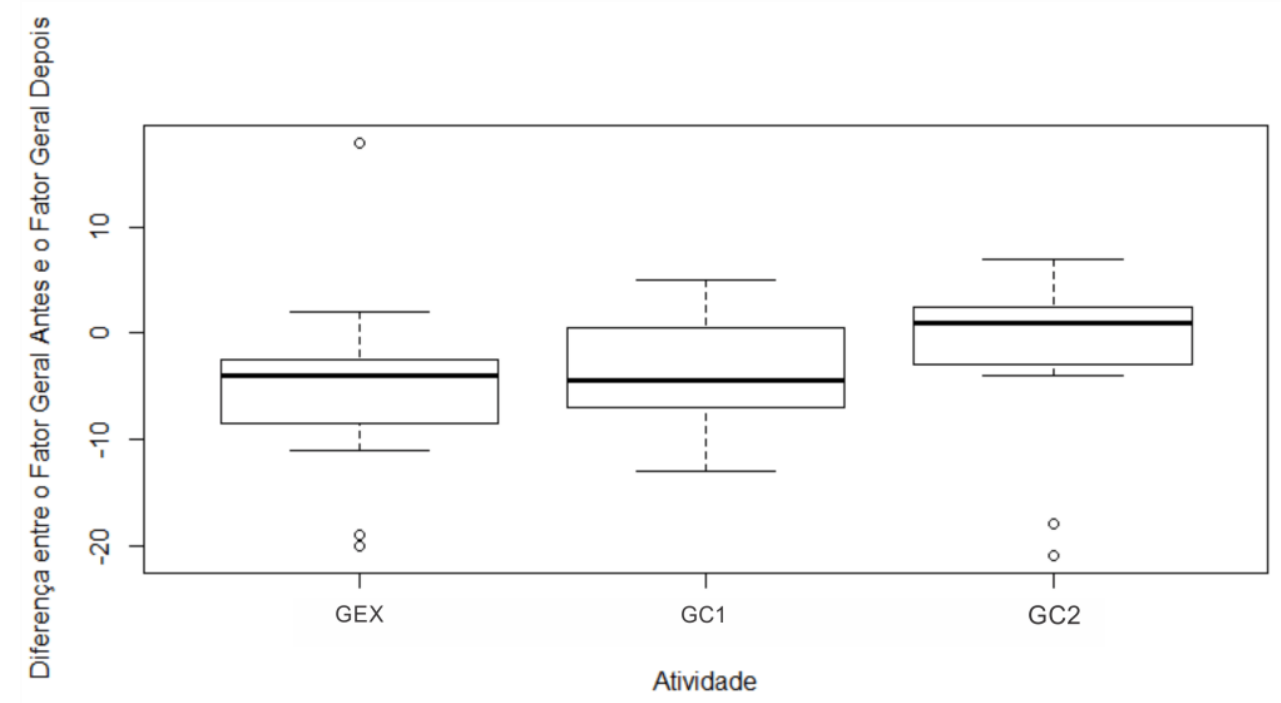

Fonte: Elaborado a partir dos dados obtidos no teste. 
O gráfico acima já indica uma suspeita de que não exista diferença estatisticamente significante entre as médias dos três grupos. Segue a tabela da Análise de Variância:

Tabela 9 - Tabela da Análise de Variância da diferença entre o Fator Geral Antes e Fator Geral Depois

\begin{tabular}{cccccc}
\hline $\begin{array}{c}\text { Fonte de } \\
\text { Variação }\end{array}$ & $\begin{array}{c}\text { Graus de } \\
\text { Liberdade }\end{array}$ & $\begin{array}{c}\text { Soma de } \\
\text { Quadrados }\end{array}$ & $\begin{array}{c}\text { Quadrado } \\
\text { Médio }\end{array}$ & Estatística F & p-valor \\
\hline Atividades & 2 & 206,10 & 103,03 & 2,182 & 0,129 \\
Resíduos & 33 & $1.558,20$ & 47,22 & & \\
\hline TOTAL & 35 & $\mathbf{1 . 7 6 4 , 3 0}$ & & & \\
\hline
\end{tabular}

Fonte: Elaborado a partir dos dados obtidos no teste.

O p-valor indica que não há indícios suficientes para rejeitar a hipótese nula. Logo, a um nível de significância de $5 \%$, conclui-se que as médias da diferença entre o Fator Geral Antes e Fator Geral Depois do GEX, GC1 e GC2 são estatisticamente iguais. Ou seja, mesmo com os ganhos superiores do GEX em relação aos demais, os dados não foram suficientes para comprovar estatisticamente essa diferença, quando comparamos os três grupos de forma conjunta.

\subsection{COMPARAÇÕES DE MÉDIAS ENTRE O FATOR GERAL PRET E O FATOR GERAL POST}

\subsubsection{Por sexo}

Para a comparação de médias entre o Fator Geral PreT e o Fator Geral PosT por sexo, mais uma vez será feito um teste de hipótese. Consideram-se as amostras dos grupos de interesse como dependentes. As hipóteses são:

$\mathrm{H}_{0}$ : As médias do Fator Geral Antes e do Fator Geral Depois são iguais por sexo.

$\mathrm{H}_{1}$ : As médias do Fator Geral Antes e do Fator Geral Depois diferem por sexo.

Os dados para o sexo feminino não atendem à suposição de Normalidade, logo, o Teste de Wilcoxon foi aplicado e retornou p-valor igual a 0,0213. Para um nível de significância de $5 \%$, a hipótese nula é rejeitada. Portanto, as médias dos 
escores obtidos no Fator Geral PreT e do Fator Geral PosT não são iguais para o sexo feminino.

A suposição de Normalidade é aceita para o caso do sexo masculino. Sendo assim, o Teste $\mathrm{T}$ foi realizado e o p-valor encontrado foi de 0,0747. Assumindo 0 nível de significância de 5\%, a hipótese nula não é rejeitada, ou seja, as médias dos escores obtidos no Fator Geral PreT e Fator Geral PosT são iguais para o sexo masculino.

\subsubsection{Por grupo}

Dado que a suposição de normalidade dos dados foi atendida e que as amostras são dependentes, foi aplicado, de forma complementar aos testes anteriores, o Teste $T$ para a comparação entre as médias dos escores obtidos no Fator Geral PosT e no Fator Geral PreT. Isso visa comparar cada grupo, separadamente, visando observar alguma tendência no comportamento dos dados.

As hipóteses a seguir são as mesmas para as três atividades:

$\mathrm{H}_{0}$ : As médias do Fator Geral Depois e do Fator Geral Antes são iguais.

$\mathrm{H}_{1}$ : A média do Fator Geral Depois é maior do que a média do Fator Geral Antes

Para um nível de significância de 5\%, pode-se afirmar que o escore médio no TNVRI obtido pelos alunos do GEX após o período de intervenção é diferente do escore médio obtido no período anterior à intervenção. Além do GEX, foi possível concluir o mesmo para o GC1. Para o GC2, não houve alteração no escore médio do fator geral do TNVRI.

Tabela 10 - P-valor do Teste T por grupo

\begin{tabular}{c|c}
\hline Grupo & p-valor \\
\hline GEX & 0,0241 \\
GC1 & 0,0281 \\
GC2 & 0,2101 \\
\hline Fonte: Elaborado partir dos dados obtidos no teste
\end{tabular}

Fonte: Elaborado a partir dos dados obtidos no teste. 


\subsection{CORRELAÇÃO ENTRE EXPERTISE ENXADRÍSTICA E DESEMPENHO NO TNVRI}

Ao final do campeonato, realizado apenas entre os indivíduos do GEX, os pontos foram computados para utilização nos testes de correlação. No xadrez, uma vitória soma a pontuação do jogador à quantia de 1 (um) ponto, empate corresponde a 0,5 pontos e, em caso de derrota, o jogador recebe 0 (zero) pontos. Ao final do número de rodadas pré-determinado (4, no caso do presente estudo), somam-se os pontos de cada jogador e declara-se vencedor aquele que tiver a maior pontuação, considerando-se, em caso de empate, os critérios também previamente estabelecidos e recomendados pela Fide (Federação Internacional de Xadrez).

A pontuação obtida no campeonato foi comparada apenas aos escores obtidos no Fator Geral do PosT, que descrevem, ao final do período de intervenção, o nível de raciocínio de cada criança. A seguir, temos uma tabela que mostra os alunos (identificados por letras, a fim de preservar suas identidades), os escores obtidos no TNVRI e a pontuação alcançada no campeonato ao fim da quarta rodada. Os dados estão organizados em ordem decrescente a partir do escore obtido no TNVRI. Isso facilita a visualização de uma possível correlação entre nível de raciocínio com expertise enxadrística.

Tabela 11 - Escores TNVRI e pontuação do campeonato

\begin{tabular}{c|c|c|c}
\hline Aluno & Gênero & TNVRI & Campeonato \\
\hline E & Feminino & 41 & 2 \\
H & Feminino & 36 & 1,5 \\
G & Feminino & 34 & 2 \\
F & Masculino & 33 & 3 \\
C & Masculino & 31 & 2 \\
D & Feminino & 27 & 2,5 \\
A & Feminino & 25 & 3 \\
I & Feminino & 25 & 1 \\
J & Feminino & 19 & 2 \\
B & Masculino & 11 & 1,5 \\
Média & & $\mathbf{2 8 , 2}$ & $\mathbf{2 , 0 5}$ \\
\hline
\end{tabular}

Fonte: Elaborado a partir dos dados obtidos no teste e no campeonato. 
A seguir, temos os dados dispostos graficamente. É possível perceber a dificuldade em encontrar alguma correlação entre os dados, pois jogadores que obtiveram bons escores no TNVRI não obtiveram, necessariamente, bons resultados no campeonato, como o sujeito $A$ ou o sujeito $E$, por exemplo.

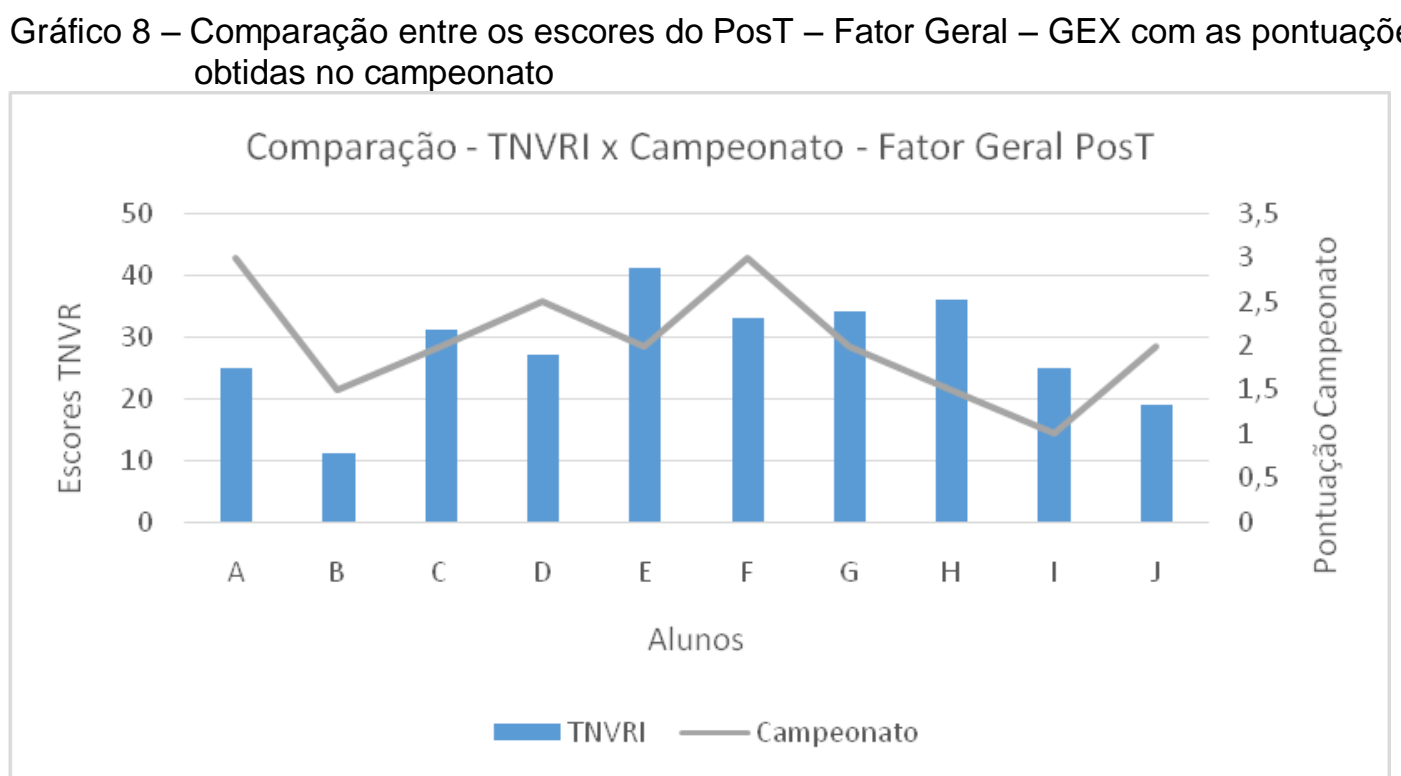

Fonte: Elaborado a partir dos dados obtidos no teste e no campeonato.

Apenas observando os gráficos e tabelas, é possível inferir que não houve correlação entre os dados obtidos, pois o valor encontrado de $r$ foi de $+0,1753$. Apesar de indicar uma correlação positiva dos dados, ou seja, que, à medida que crescem os escores no Fator Geral do TNVRI, crescem também os pontos obtidos no campeonato, tal correlação não é forte o suficiente para que possamos chegar a qualquer parecer ou conclusão.

Objetivando uma melhor visualização dessa conclusão, temos a seguir um gráfico de dispersão que nos auxilia a observar melhor e corroborar com mais ênfase a conclusão da ausência de correlação entre o resultado obtido no TNVRI com os resultados obtidos no campeonato. Pelo gráfico podemos ver como os dados se dispersam de forma aleatória, não denotando qualquer tipo de tendência, seja ela ascendente ou descendente: 
Gráfico 9 - Comparação entre os escores do PosT - Fator Geral - GEX com as pontuações obtidas no campeonato

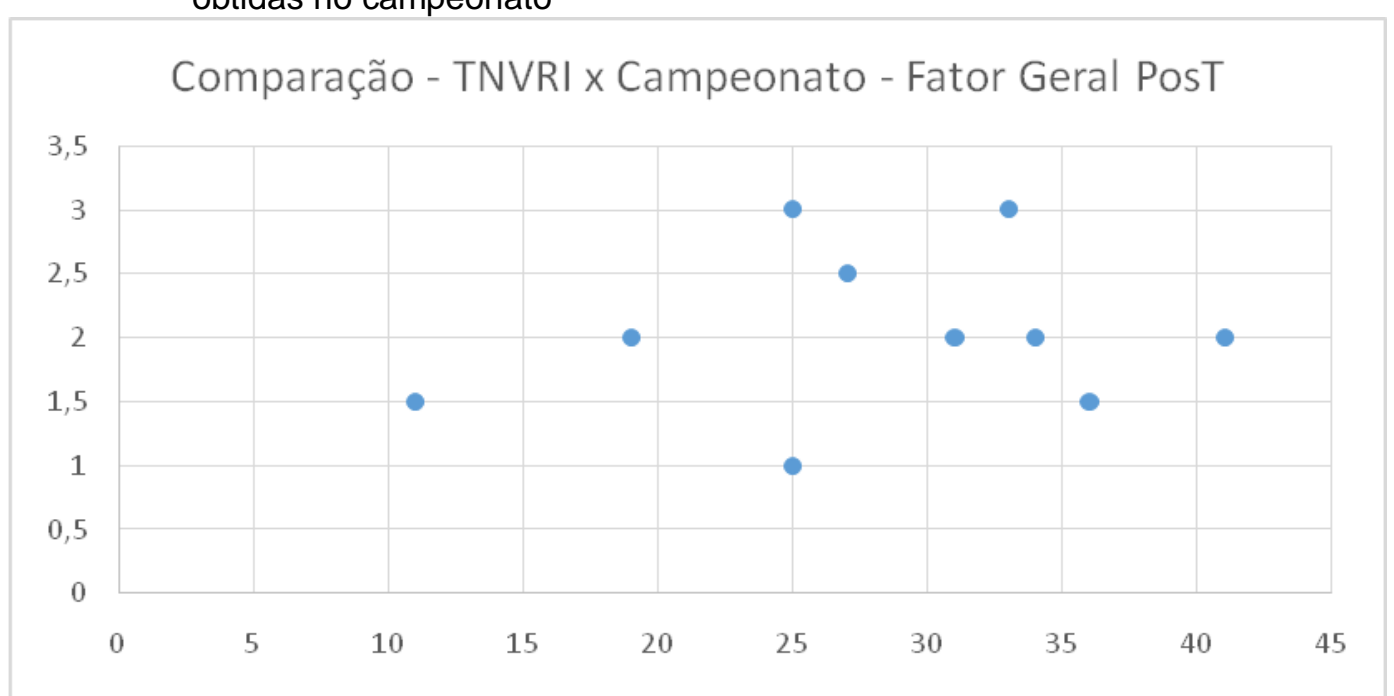

Fonte: Elaborado a partir dos dados obtidos no teste e no campeonato. 


\section{DISCUSSÃO}

\subsection{O QUE DISSERAM OS ESTUDOS SEMELHANTES?}

Fergusson (1988) conduziu um estudo semelhante com 14 alunos da $6^{\underline{a}}$ série (9 meninos e 5 meninas) em uma escola rural na Pensilvânia, que receberam lições de xadrez 2 ou 3 vezes por semana durante 8 meses. O delineamento foi semelhante, pois foi conduzido um pré-teste e um pós-teste usando os subtestes de "memória" e "raciocínio verbal" da bateria de testes de avanço da Califórnia. Porém, não foi utilizado um grupo controle com alguma atividade diferente do xadrez, já que as diferenças entre o pós-teste e pré-teste foram comparadas apenas com as médias nacionais. Na tabela a seguir, podemos ver resumidamente os resultados obtidos nos testes:

Tabela 12 - Sumário estatístico - Teste $t$ - Test of Cognitive Skills - TCS
\begin{tabular}{||ccc||}
\hline \hline & MEMORY & VERBAL REASONING \\
TABLES & $p<$ & $p<$ \\
& & \\
MALES \& FEMALES COMBINED: & $\mathbf{0 . 0 0 1}$ & $\mathbf{0 . 0 0 2}$ \\
Dependent Chess Group & $\mathbf{0 . 0 0 1}$ & 0.066 \\
Population Mean Chess vs. National Norms & & \\
MALES: & $\mathbf{0 . 0 0 1}$ & $\mathbf{0 . 0 1}$ \\
Dependent Chess Group & $\mathbf{0 . 0 0 1}$ & 0.128 \\
Population Mean Chess vs. National Norms & & \\
FEMALES: & 0.045 & 0.11 \\
Dependent Chess Group & 0.077 & 0.406 \\
Population Mean Chess vs. National Norms & & \\
\hline
\end{tabular}

Fonte: Ferguson (2001, p. 83).

Pela Tabela 12, podemos ver que os resultados significativos foram encontrados quando comparado o grupo que frequentou as aulas de xadrez com a média nacional, no que se refere à memória. Também foram encontrados resultados estatisticamente significativos ao se separar o grupo por sexo, sendo que os indivíduos do sexo masculino apresentam diferença significativa da média nacional. O mesmo não se pode dizer dos indivíduos do sexo feminino, os quais apresentaram um $p>0,05$, indicando, assim, sua semelhança com os valores padrão para a população geral. Porém, mesmo que os grupos demonstrem avanço quando comparados a si mesmos (pré-teste - pós-teste) em relação ao raciocínio verbal, 
não foram obtidas diferenças estatisticamente significativas quando comparados à média nacional.

A seguir, vemos dois gráficos que visam comparar os dados obtidos no presente estudo com os do estudo de Ferguson (2001). É possível ver que a variação dos dados em relação à média no grupo xadrez do estudo de Ferguson é menor, mas os ganhos entre PreT e PosT são semelhantes ao presente estudo.

Gráfico 10 - Comparação de escores - PreT e PosT - TCS: Subteste "Memória" - Grupo xadrez

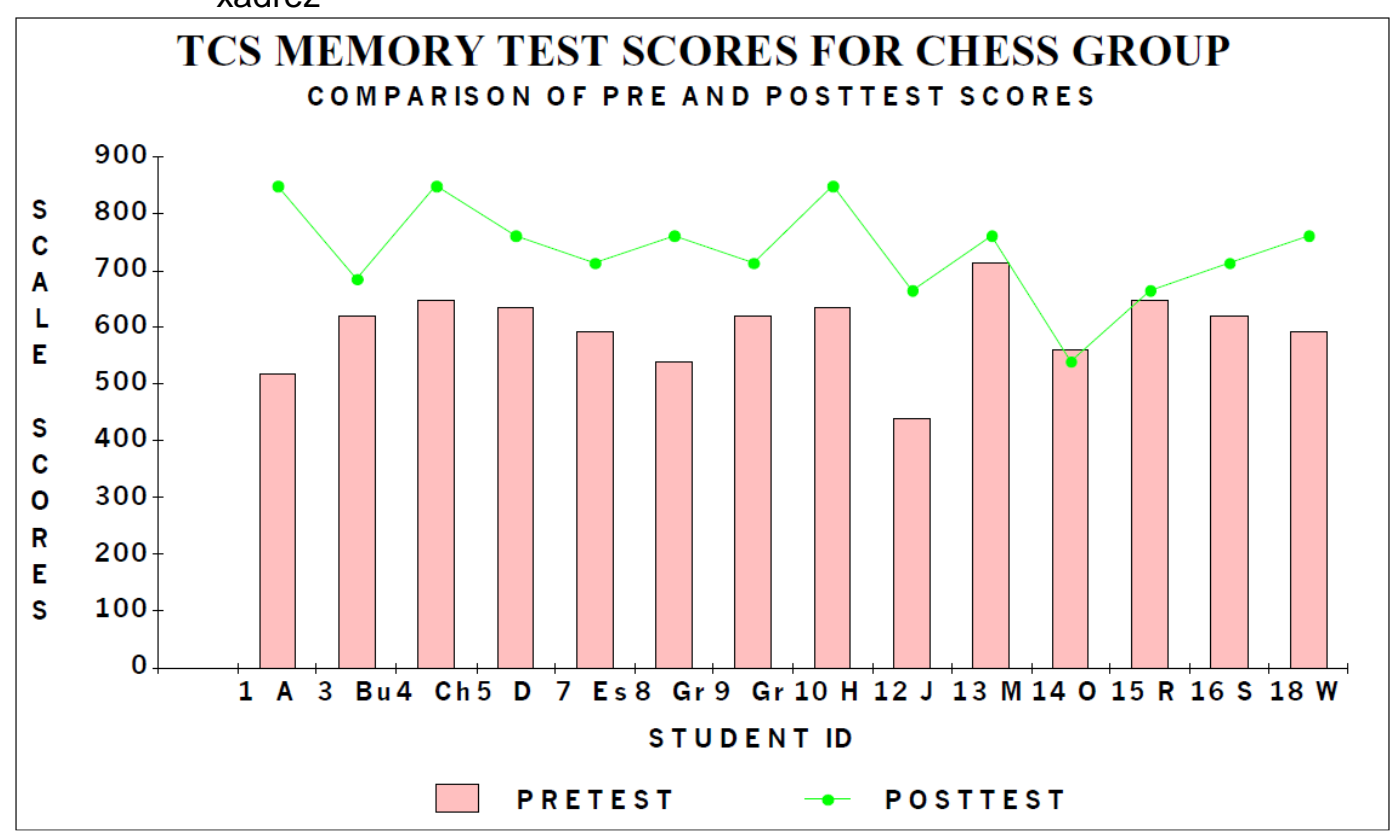

Fonte: Ferguson (2001, p. 81).

Gráfico 11 - Comparação de escores - PreT e PosT - TNVRI: Fator Geral - GEX.

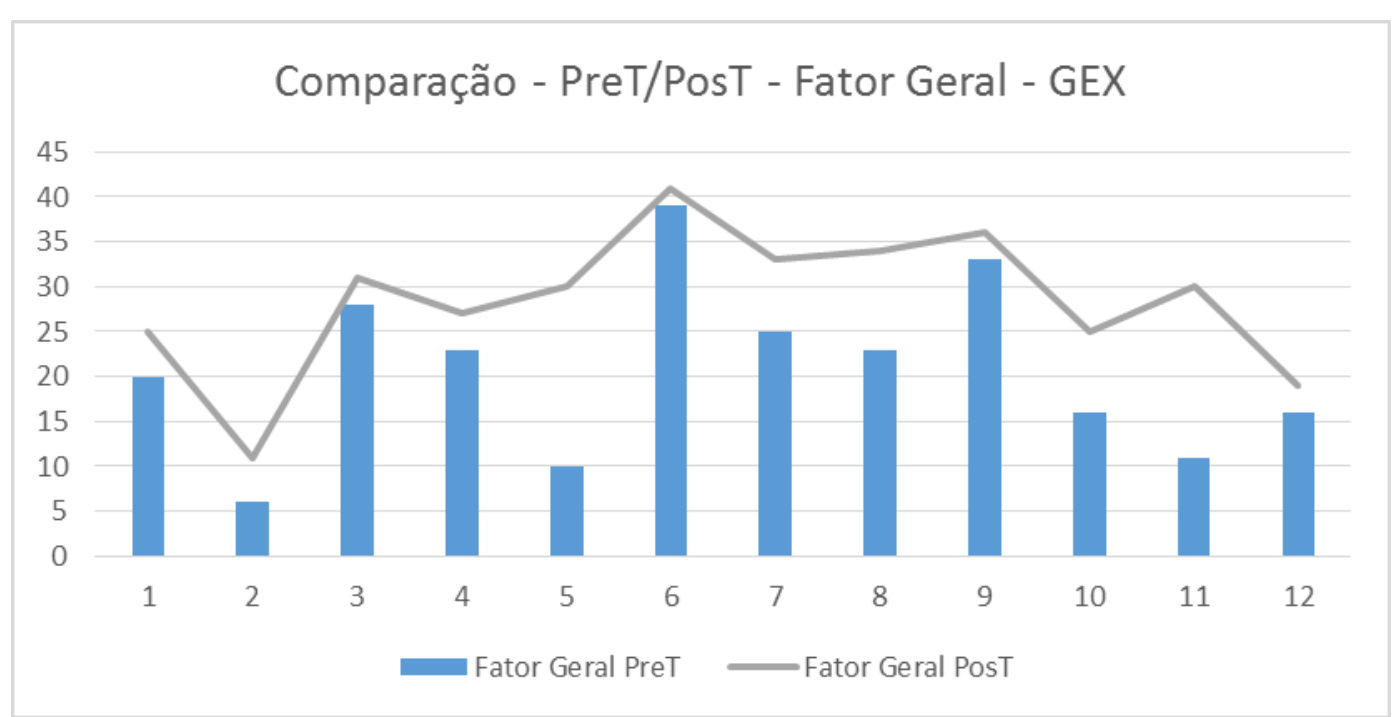

Fonte: Elaborado a partir dos dados obtidos no teste. 
Campitelli e Gobet (2007) elogiam e, ao mesmo tempo, criticam o estudo de Ferguson (2001). Os elogios se dão pela presença de um pré-teste/pós-teste e o uso de medidas bem-padronizadas ("Test of Cognitive Skills (TCS)", subtestes "memória" e "raciocínio verbal"). Mesmo que estejamos falando de diferentes situações, tais elogios podem ser absorvidos pelo presente estudo, pois este conta com a presença de um pré-teste/pós-teste, bem como o uso de medidas bem-padronizadas (Fator Geral do TNVRI).

Porém, alguns pontos são citados como deficitários. A não aleatoriedade da amostra e a ausência de um segundo grupo controle, como foi afirmado anteriormente, deixam em dúvida se foi realmente o xadrez a causa dos ganhos na memória e no raciocínio verbal. Campitelli e Gobet (2007, p. 192) citam que: "Por exemplo, os resultados podem ser explicados pelo fato de que o grupo realizou uma atividade intelectual diariamente e, nesse caso, qualquer atividade intelectual poderia ter sido tão efetiva quanto o xadrez". Além disso, a amostra foi considerada pequena. Nesse ponto, até mesmo o próprio Ferguson (2001, p. 84) confirmou que estudos posteriores devem ser encorajados, porém, com amostras maiores.

O tamanho da amostra do presente estudo $(n=36)$ foi decidido pelo tamanho de cada turma já presente na escola onde o estudo foi conduzido. As turmas foram escolhidas, diferentemente do estudo de Ferguson (2001), aleatoriamente para participar do estudo, mas todos os indivíduos de cada grupo pertenciam à mesma turma. Isso facilita o controle de algumas variáveis, tais como a diferença na condução de uma aula para outra, caso os grupos estivessem divididos em mais turmas. Porém, o número reduzido de participantes também pode ter sido a causa para que muitos testes estatísticos acusassem diferenças não significativas entre os grupos.

Fried e Ginsburg [1985?] conduziram um estudo no Brooklin, Nova York, onde 30 alunos de $4^{\circ}$ e $5^{\circ}$ grau (15 meninos e 15 meninas), que apresentavam leves problemas comportamentais e de aprendizagem, foram designados aleatoriamente para três grupos: xadrez, aconselhamento psicológico e sem contato. A instrução enxadrística era composta por aulas, demonstrações e partidas. Após 18 semanas, foram administrados três testes: o subteste de complementação de figuras da escala de inteligência revisada infantil de Weschler (WISC-R), que mede a habilidade perceptual e, em particular, a detecção de detalhes visuais; o subteste de desenho 
de blocos do mesmo teste, que mede a habilidade visuoespacial; e uma pesquisa de atitudes escolares.

As semelhanças com o presente estudo começam pela distribuição dos indivíduos. Em ambos os estudos, uma amostra balanceada foi dividida em três grupos, sendo um experimental, um placebo e um grupo controle. Isso, como Campitelli e Gobet (2007, p. 184) afirmaram, constitui um desenho experimental mais robusto, pois, caso o grupo experimental demonstre algum incremento em relação ao grupo placebo, seria possível concluir que "o efeito se deve a algumas características do grupo de tratamento e não a fatores inespecíficos, com a participação em um experimento". Outra semelhança está na distribuição de gêneros da amostra, pois ambas estão perfeitamente balanceadas, sendo $50 \%$ dos indivíduos da amostram são do sexo masculino e os outros $50 \%$ são do sexo feminino.

O WISC-R, teste utilizado no estudo de Fried e Ginsburg [1985], em muito se assemelha ao TNVRI, principalmente nos subtestes utilizados. Ambos se propõem a analisar, de forma não verbal, a inteligência de crianças por meio da complementação de figuras simples, exigindo da criança apenas a capacidade de perceber diferenças ou similaridades em cada uma, preenchendo corretamente uma lacuna. A seguir, podemos ver um exemplo de figura que compõe o WISC-R, percebendo assim a semelhança com as figuras presentes no TNVRI.

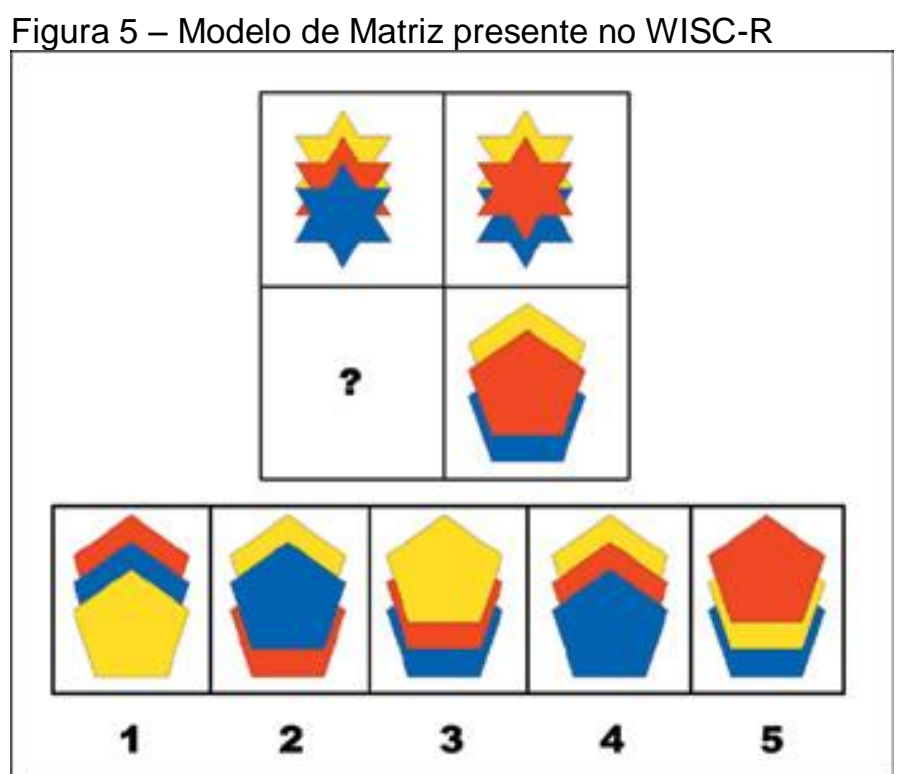

Fonte: WECHSLER, 1974. 
Porém, a semelhança mais importante se deu nos resultados dos estudos. Em ambos, não foram encontradas diferenças estatisticamente significativas entre os grupos experimental, placebo e controle. A justificativa mais provável para não terem sido encontradas diferenças em ambos os estudos está novamente no tamanho da amostra. No estudo de Ferguson (2001), a amostra era composta por apenas 14 indivíduos. Já no estudo de Fried e Ginsburg [1985?], a amostra é maior, 30. Porém, mesmo tendo aumentado a quantidade de indivíduos para 32, ainda assim não foi possível encontrar diferenças significativas entre os grupos experimental, placebo e controle. Isso indica que um dos fatores que pode ter influenciado os resultados em direção a uma diferença estatisticamente insignificante no presente estudo tenha sido o tamanho da amostra.

\subsection{EXISTEM DIFERENÇAS DE RACIOCÍNIO ENTRE OS SEXOS?}

Primeiramente, podemos ver que as amostras foram balanceadas em relação ao sexo, ou seja, participou do estudo a mesma quantidade de indivíduos do sexo masculino como do sexo feminino. Porém, essa distribuição da amostra não segue a tendência mundial, pelo menos no que se refere ao xadrez de alto nível. É comprovado estatisticamente que o número de homens que praticam xadrez é maior que o número de mulheres. A Fide (Fédération Internationale des Échecs ou, em inglês, World Chess Federation) possuía 189.615 jogadores cadastrados com rating ELO, que consiste em um sistema capaz de calcular a força relativa de enxadristas, criado pelo físico húngaro naturalizado norte-americano Arpad Elo. Esse cadastro nos permite ter uma ideia geral de quantos homens e quantas mulheres jogam xadrez pelo mundo. O número de mulheres cadastradas até outubro de 2014 era de 17.733. Já o número de homens era de 171.882. Isso equivale praticamente a 10 homens para cada mulher (FIDE, 2014).

Por mais que pareça deveras chocante, essa estatística vem sendo reduzida gradativamente ao longo do tempo. Bilalic et al. (2009) estudaram os indicativos que pudessem explicar o número reduzido de mulheres em atividades com alto índice de exigência intelectual e cognitiva, tais como o xadrez ou a ciência. Em seu estudo, ele afirmou que o número de jogadores homens com Rating Fide era de 113.386, enquanto o número de mulheres era de 7.013. Isso representava uma média de 16 homens para cada mulher. 
Silva (2010) também confirmou que o número de homens que praticam xadrez é bem maior que o número de mulheres. Ele cita uma pesquisa feita na Holanda nos anos de 1997 e 1998, intitulada Queen's move (KRUK; SEIRAWAN; REERINK, 2000, p. 48), que mostra a porcentagem de $5,14 \%$ de mulheres praticantes de xadrez registradas na KNSB (Royal Dutch Chess Federation ou Federação Real Holandesa de Xadrez, tradução nossa). Para outros jogos de tabuleiro, como damas e go, o número de mulheres praticantes também foi bastante baixo (3,7\% e 7,37\% respectivamente). Porém, cabe ressaltar que tal pesquisa não foi baseada no número de jogadores cadastrados na Fide.

\begin{tabular}{|c|c|c|c|c|c|c|}
\hline \multicolumn{7}{|c|}{ KNSB } \\
\hline year & $\begin{array}{l}\text { applicants } \\
\text { up to } 15\end{array}$ & $\begin{array}{l}\text { juniors } \\
\text { up to } 19\end{array}$ & $\begin{array}{c}\text { seniors } \\
20+\end{array}$ & $\begin{array}{l}\text { total fem. } \\
\text { members }\end{array}$ & $\begin{array}{c}\text { total } \\
\text { members }\end{array}$ & $\begin{array}{c}\text { female } \\
\%\end{array}$ \\
\hline 1988 & 748 & 69 & 493 & 1310 & & \\
\hline 1994 & 762 & 67 & 565 & 1394 & 29955 & 4,65 \\
\hline 1995 & 740 & 61 & 553 & 1354 & 29314 & 4,62 \\
\hline 1996 & 690 & 64 & 516 & 1270 & 28272 & 4,49 \\
\hline 1997 & 675 & 65 & 524 & 1264 & 27657 & 4,57 \\
\hline 1998 & 737 & 72 & 518 & 1327 & 27354 & 4,85 \\
\hline 1999 & 817 & 65 & 510 & 1392 & 27105 & 5,14 \\
\hline
\end{tabular}

Fonte: KRUK; SEIRAWAN; REERINK, 2000, p. 48.

Primeiramente, há de se deixar claro que não há evidências empíricas tanto para o porquê de existirem mais homens do que mulheres que jogam xadrez, nem o porquê dos homens possuírem ratings maiores que os das mulheres. A superioridade masculina no xadrez é frequentemente citada por alguns autores como um exemplo da superioridade intelectual nata dos homens. Porém, como veremos mais adiante, essa é uma crença equivocada.

Os melhores jogadores do sexo masculino são indiscutivelmente melhores do que as melhores jogadoras do sexo feminino. Por exemplo: nem uma única mulher foi campeã mundial; apenas 1 por cento dos Grandes Mestres, os melhores jogadores do mundo, são do sexo feminino; e há apenas uma mulher entre os 100 melhores jogadores do mundo (BILALIC et al., 2009, p. 1.162 , tradução nossa). 
Porém, o mesmo autor afirmou que esse é um assunto extremamente debatido, mas que ainda carece de evidências conclusivas, e apontou que a diferença entre desempenhos pode ter uma explicação simples:

\begin{abstract}
Ao considerar tais exemplos aparentemente convincentes da superioridade masculina no mundo real, pode-se facilmente se esquecer de considerar a grande disparidade no número de participantes e das consequências estatísticas disso para o provável gênero dos melhores jogadores (BILALIC, 2009, p. 1.162, tradução nossa).
\end{abstract}

Ao concluir seu estudo, Bilalic et al. (2009, p. 1.163, tradução nossa) confirmaram que a grande diferença entre o número de participantes pode ser o ponto para se explicar a diferença entre performance entre homens e mulheres:

Este estudo demonstra que a grande discrepância no melhor desempenho de jogadores de xadrez masculino e feminino pode ser em grande parte atribuída a um simples fato estatístico - mais valores extremos são encontrados em populações maiores.

Dessa forma, vemos que a superioridade masculina no xadrez pode ser explicada apenas pela maior quantidade de homens praticando, relação essa que vem caindo exponencialmente ao longo dos anos. No presente estudo, mesmo que seja comprovada a maior participação de homens do que de mulheres no xadrez, foi tomada a decisão de balancear igualitariamente as amostras, já que, em níveis escolares, não se percebe tão claramente a preferência maior de xadrez pelos meninos do que pelas meninas. Tal fato pode ser comprovado pela facilidade em compor a amostra, pois tanto meninas quanto meninos se mostraram entusiasmados e comprometidos em aprender a jogar xadrez.

No estudo de Ferguson (2001), citado anteriormente, foram encontrados dados interessantes sobre as diferenças de performance entre os gêneros. $O$ principal deles foi o de que os meninos obtiveram resultados melhores do que as meninas. Enquanto o p-valor do grupo masculino, quando comparado com a média nacional, foi de 0,001 (altamente significativo), o p-valor do grupo feminino foi de 0,077 (não significativo). Ou seja, o ganho dos meninos foi estatisticamente superior à média nacional, enquanto o das meninas não apresentou diferenças significativas. Porém, essa conclusão se encaminha em direção oposta à sugerida pelo presente estudo. No TNVRI, as meninas obtiveram resultados estatisticamente significantes quando comparados os escores do PreT com os escores do PosT, pois o teste 
utilizado (Teste de Wilcoxon para Amostras Dependentes) retornou p-valor igual a 0,0213. Sendo assim, para um nível de significância de $5 \%$, a hipótese nula é rejeitada. Ou seja, a média dos escores foi maior após a prática do xadrez.

Já em relação ao sexo masculino, o p-valor é de 0,0747. Assumindo o nível de significância de $5 \%$, a hipótese nula não é rejeitada, ou seja, as médias do Fator Geral Antes e Fator Geral Depois são iguais para o sexo masculino. Isso pode indicar uma tendência citada anteriormente, que é a da equalização de desempenho em jogos cognitivos entre meninos e meninas, homens e mulheres.

Outro estudo que indicou uma superioridade masculina foi o de Fried e Ginsburg [1985?]. Em algumas análises adicionais, foi possível mostrar a presença de uma interação entre o sexo e tratamento apenas nos testes de desenho de blocos e na pesquisa de atitudes escolares. No teste de desenho de bloco, as meninas pontuaram significativamente abaixo do que os meninos no grupo enxadrístico, mas não foram encontradas diferenças nos demais grupos. Ou seja, apenas no grupo que participou das aulas de xadrez, observou-se uma diferença significativa entre o desempenho de meninos e meninas, sendo que os meninos obtiveram resultados melhores.

Vale ressaltar que o estudo de Ferguson (2001) foi conduzido há 26 anos atrás. Nessa época, a razão entre homens/mulheres praticando o xadrez era enormemente maior que a atual, conduzindo, assim, a um sentimento inconsciente de impotência e inferioridade das mulheres perante os homens.

Porém, como também foi indicado, essa realidade muda a cada dia. Tanto em níveis profissionais como em ambiente escolar, a participação, e consequente bom desempenho, de mulheres em campeonatos de xadrez cresce exponencialmente. Se analisarmos, como foi observado anteriormente, os dados da Fide (2014), vemos que eles apontam a razão de 10 homens para cada mulher registrada em seu sistema. Se Bilalic et al. (2009) encontraram uma razão de 16 homens por mulher há 6 anos atrás, seguindo uma lógica matemática simples, a razão de homens por mulher praticando xadrez na época do estudo de Ferguson (2001) era de 36 homens para cada mulher. Talvez esse seja um indicativo que justifique superficialmente os resultados superiores do sexo masculino sobre o sexo feminino. 


\title{
5.3 EXISTE CORRELAÇÃO ENTRE EXPERTISE ENXADRÍSTICA E RACIOCÍNIO?
}

O presente estudo teve por objetivo específico avaliar, além das possíveis diferenças entre gênero, a possível correlação entre expertise enxadrística e raciocínio. Para isso, por meio da correlação de Pearson, foram correlacionados os dados obtidos no PosT do TNVRI, contabilizando apenas os escores do Fator Geral, com a pontuação obtida pelos alunos em um campeonato de xadrez realizado no último dia de aula. Como foi possível ver nos resultados, não foi possível indicar qualquer tipo de correlação entre os dados, pois o valor de $r$ foi de apenas $+0,1753$.

Alguns estudos semelhantes podem ser citados, mas o de Silva (2010, p. ix) é um dos mais expressivos para avaliarmos esse caso em específico. Na investigação, o objetivo foi pesquisar se havia correlação positiva entre os desempenhos no jogo de xadrez e na Escala de Desenvolvimento do Pensamento Lógico (EDPL).

\begin{abstract}
Participaram desta pesquisa trinta enxadristas estudantes de Ensino Médio em uma escola pública de Curitiba, divididos, conforme sua proficiência em xadrez, em três grupos de dez estudantes: básico, intermediário e avançado. Foram utilizados três tipos de instrumentos para a coleta de dados: a escala para avaliação do nível de desenvolvimento cognitivo (Escala de Desenvolvimento do Pensamento Lógico - EDPL); partidas de todos os estudantes contra um programa de computador; e um torneio de xadrez entre os estudantes do grupo avançado. A análise dos dados foi dividida em quatro momentos principais. Primeiro, análise das partidas jogadas contra o computador, com os objetivos de caracterizar e comparar o desempenho enxadrístico dos grupos, e calcular seu índice de expertise no xadrez. Segundo, comparação entre nível enxadrístico e desempenho na EDPL, para identificar em quais provas da EDPL os participantes apresentaram melhor desempenho. Terceiro, comparações de desempenho no torneio de xadrez, realizado com o grupo avançado, e desempenho na EDPL, para verificar se os desempenhos foram semelhantes. Por último, foram efetuadas comparações entre sexo, idade e série escolar na EDPL, para verificar possíveis diferenças entre estas variáveis na EDPL. A análise dos dados mostrou que o desempenho geral na EDPL dos estudantes do grupo avançado foi $31,7 \%$ superior ao dos demais estudantes. Das quatro provas da EDPL que exigem nível cognitivo formal, os estudantes do grupo avançado tiveram desempenho superior em três: permutações, com desempenho $50 \%$ superior; probabilidade, com desempenho $27,15 \%$ superior; e curvas mecânicas, com desempenho 46,73\% superior. Assim, os dados deste estudo permitiram afirmar que existe uma correlação positiva entre desempenho enxadrístico e desempenho na EDPL.
\end{abstract}

Portanto, de acordo com a pesquisa de Silva (2010), podemos sugerir que jogadores mais fortes possuem raciocínio mais avançado do que jogadores mais fracos. Contudo, é necessário expor alguns detalhes antes de compará-la ao presente estudo. Primeiramente, os participantes não foram divididos em grupos "avançado", "intermediário" e "básico" com base na pontuação do campeonato, que 
também foi realizado, mas sim em diversos outros fatores que foram observados e avaliados separadamente. Podemos ver detalhado mais claramente esses fatores na seguinte passagem:

As partidas contra o software Fritz, bem como a entrevista sobre o
conhecimento das regras básicas do xadrez (que foram realizadas apenas
com os participantes básicos e intermediários), tiveram a dupla finalidade
de: a) caracterizar o grupo de básicos e intermediários no xadrez; e b)
comparar o desempenho enxadrístico dos três grupos (SILVA, 2010, p.
165).

Além disso, o professor selecionou, para o grupo avançado, os 10 melhores jogadores de acordo com o desempenho em competições anteriores. Portanto, não podemos comparar os indivíduos de ambos os estudos de acordo com a expertise enxadrística, pois ela foi definida por indicadores diferentes. Isso ajuda a entender o porquê de os estudos obterem resultados opostos, já que Silva (2010) obteve correlação positiva entre desempenho enxadrístico (mensurado pelo conhecimento das regras e partidas contra um software) e desempenho na EDPL (que avalia os níveis de raciocínio), e o presente estudo, que não obteve qualquer tipo de correlação entre o desempenho enxadrístico (mensurado pelo desempenho no campeonato) e os escores do Fator Geral no PosT (que também avalia os níveis de raciocínio).

Outro detalhe importante é o de que a correlação não foi unânime em todos os subtestes da EDPL. Em alguns deles, a hipótese nula, ou seja, de que não houve diferença entre os grupos avançado, intermediário e básico, não foi rejeitada. Dessa forma, foi possível afirmar que as diferenças de expertise enxadrística não produziram diferenças significativas nos resultados de alguns subtestes da EDPL. Como exemplo, podemos citar a comparação entre avançados e não avançados na prova da conservação (um dos testes do EDPL). Nesse caso em específico, a hipótese nula não foi rejeitada, ou seja, o desempenho de ambos os grupos foi estatisticamente semelhante.

A seguir, temos um quadro retirado do estudo de Silva (2010, p. 197), que mostra mais detalhadamente as comparações, hipóteses, testes e conclusões obtidas. 
Quadro 1 - Comparações, hipóteses, testes estatísticos e conclusões do estudo de Silva (2010)

\begin{tabular}{|c|c|c|c|c|}
\hline $\mathrm{N}$ & COMPARAÇŌES & HIPÖTESES & $\begin{array}{c}\text { TESTE } \\
\text { ESTATISTICO } \\
\end{array}$ & CONCLUSŌES \\
\hline 1 & $\begin{array}{l}\text { Entre básicos e } \\
\text { intermediários, na } \\
\text { EDPL }\end{array}$ & $\begin{array}{l}\mathrm{H}_{0}=\text { Não existe diferença entre o desempenho } \\
\text { dos enxadristas básicos e intermediários. } \\
\mathrm{H}_{1}=\text { Os enxadristas intermediários têm melhor } \\
\text { desempenho do que os básicos. }\end{array}$ & $\begin{array}{l}\text { Wilcoxon-Mann- } \\
\text { Whitney para } 2 \\
\quad \text { amostras } \\
\text { independentes } \\
95 \%(a=0,05)\end{array}$ & $\begin{array}{l}\mathrm{H}_{0} \text { não } \\
\text { rejeitada }\end{array}$ \\
\hline 2 & $\begin{array}{l}\text { Entre avançados e } \\
\text { näo-avançados } \\
\text { (básicos e } \\
\text { intermediários), na } \\
\text { EDPL }\end{array}$ & $\begin{array}{l}\mathrm{H}_{0}=\text { Não existe diferença entre o desempenho } \\
\text { dos enxadristas avançados e näo-avançados } \\
\text { (básicos e intermediários). } \\
\mathrm{H}_{1}=\text { Os enxadristas avançados têm melhor } \\
\text { desempenho do que os não-avançados. }\end{array}$ & $\begin{array}{l}\text { Wilcoxon-Mann- } \\
\text { Whitney para } 2 \\
\quad \text { amostras } \\
\text { independentes } \\
95 \%(a=0,05)\end{array}$ & $\mathrm{H}_{0}$ rejeitada \\
\hline 3 & $\begin{array}{l}\text { Entre avançados e } \\
\text { näo-avançados, } \\
\text { na prova da } \\
\text { conservaçäo, na } \\
\text { EDPL }\end{array}$ & $\begin{array}{l}\mathrm{H}_{0}=\text { Não existe diferença entre o desempenho } \\
\text { dos enxadristas avançados e não-avançados na } \\
\text { prova da conservaçäo. } \\
\mathrm{H}_{1}=\text { Os enxadristas avançados têm melhor } \\
\text { desempenho do que os näo avançados, na prova } \\
\text { da conservaçäo. }\end{array}$ & $\begin{array}{l}\text { Qui-quadrado } \\
\left(X^{2}\right) \text { para } 2 \\
\text { amostras } \\
\text { independentes } \\
95 \%(a=0,05)\end{array}$ & $\begin{array}{l}\mathrm{H}_{0} \text { não } \\
\text { rejeitada }\end{array}$ \\
\hline 4 & $\begin{array}{l}\text { Entre avançados e } \\
\text { näo-avançados, } \\
\text { na prova da } \\
\text { permutaçäo, na } \\
\text { EDPL }\end{array}$ & $\begin{array}{l}\mathrm{H}_{0}=\text { Não existe diferença entre o desempenho } \\
\text { dos enxadristas avançados e não-avançados na } \\
\text { prova da permutacão. } \\
\mathrm{H}_{1}=\text { Os enxadristas avançados têm melhor } \\
\text { desempenho do que os näo avançados, na prova } \\
\text { da permutaçäo. }\end{array}$ & $\begin{array}{l}\text { Qui-quadrado } \\
\left.\qquad \mathrm{X}^{2}\right) \text { para } 2 \\
\text { amostras } \\
\text { independentes } \\
95 \%(a=0,05)\end{array}$ & $\mathrm{H}_{0}$ rejeitada \\
\hline 5 & $\begin{array}{c}\text { Entre avançados e } \\
\text { näo-avançados, } \\
\text { na prova da } \\
\text { probabilidade, na } \\
\text { EDPL }\end{array}$ & $\begin{array}{l}\mathrm{H}_{0}=\text { Não existe diferença entre o desempenho } \\
\text { dos enxadristas avançados e não-avançados na } \\
\text { prova da probabilidade. } \\
\mathrm{H}_{1}=\text { Os enxadristas avançados têm melhor } \\
\text { desempenho do que os näo avançados, na prova } \\
\text { da probabilidade. }\end{array}$ & $\begin{array}{l}\text { Qui-quadrado } \\
\left(X^{2}\right) \text { para } 2 \\
\text { amostras } \\
\text { independentes } \\
95 \%(a=0,05)\end{array}$ & $\mathrm{H}_{0}$ rejeitada \\
\hline 6 & $\begin{array}{c}\text { Entre avançadose } \\
\text { näo-avançados, } \\
\text { na prova das } \\
\text { curvas mecânicas, } \\
\text { na EDPL }\end{array}$ & $\begin{array}{l}\mathrm{H}_{0}=\text { Não existe diferença entre o desempenho } \\
\text { dos enxadristas avançados e não-avançados na } \\
\text { prova das curvas mecânicas. } \\
\mathrm{H}_{1}=\text { Os enxadristas avançados têm melhor } \\
\text { desempenho do que os näo avançados, na prova } \\
\text { das curvas mecánicas. }\end{array}$ & $\begin{array}{l}\text { Qui-quadrado } \\
\left(\mathrm{X}^{2}\right) \text { para } 2 \\
\text { amostras } \\
\text { independentes } \\
95 \%(a=0,05)\end{array}$ & $\mathrm{H}_{0}$ rejeitada \\
\hline 7 & $\begin{array}{l}\text { Entre os alunos do } \\
\text { sexo masculino e } \\
\text { feminino, na EDPL }\end{array}$ & $\begin{array}{l}\mathrm{H}_{0}=\text { Não existe diferença entre o desempenho } \\
\text { dos alunos do sexo masculino e feminino. } \\
\mathrm{H}_{1}=\text { Há diferença. }\end{array}$ & $\begin{array}{c}\text { Wilcoxon-Mann- } \\
\text { Whitney para } 2 \\
\text { amostras } \\
\text { independentes } \\
95 \%(a=0,05)\end{array}$ & $\begin{array}{l}\mathrm{H}_{0} \text { não } \\
\text { rejeitada }\end{array}$ \\
\hline 8 & $\begin{array}{c}\text { Entre idades, na } \\
\text { EDPL }\end{array}$ & $\begin{array}{l}\mathrm{H}_{0}=\text { Não existe diferença entre o desempenho } \\
\text { dos participantes, no tocante às idades. } \\
\mathrm{H}_{1}=\text { Há diferença. }\end{array}$ & $\begin{array}{l}\text { Kruskal-Wallis } \\
\text { por postos } \\
95 \%(a=0,05)\end{array}$ & $\begin{array}{l}\mathrm{H}_{0} \text { não } \\
\text { rejeitada }\end{array}$ \\
\hline 9 & $\begin{array}{c}\text { Entre séries, na } \\
\text { EDPL }\end{array}$ & $\begin{array}{l}\mathrm{H}_{0}=\text { Não existe diferença entre o desempenho } \\
\text { dos participantes no tocante às séries. } \\
\mathrm{H}_{1}=\mathrm{Há} \text { diferença. }\end{array}$ & $\begin{array}{l}\text { Kruskal-Wallis } \\
\text { por postos } \\
95 \%(a=0,05)\end{array}$ & $\begin{array}{l}\mathrm{H}_{0} \text { não } \\
\text { rejeitada }\end{array}$ \\
\hline
\end{tabular}

Fonte: SILVA, 2010, p. 197.

Outro ponto diferente entre os estudos é a idade dos indivíduos que participaram do estudo, pois no presente estudo a idade média dos participantes foi de 7,3 anos, enquanto no estudo de Silva (2010) a média de idade era de 15,5 anos. Isso influencia nos resultados devido ao desenvolvimento biológico dos indivíduos, já que crianças com 7 anos estão entrando no estágio operatório-concreto, enquanto jovens de 15 anos já estão no estágio operatório-formal, de acordo com a teoria cognitiva de Piaget. 


\subsection{AFINAL, O XADREZ DESENVOLVE O RACIOCÍNIO?}

Segundo a hipótese desta pesquisa, os indivíduos do GEX, ou seja, do grupo que frequentou aulas de xadrez, deveriam apresentar ganhos superiores nos escores obtidos no Teste não Verbal de Raciocínio Infantil - TNVRI, se comparados aos ganhos do grupo GC1, grupo placebo com aulas de reforço, e ao GC2, grupo controle o qual não frequentou atividade complementar. Para rejeitar ou comprovar tal hipótese, temos dispostos graficamente a seguir as diferenças entre médias dos escores PreT e PosT entre os três grupos: GEX, GC1 e GC2, ao se analisar apenas os escores do Fator Geral no TNVRI:

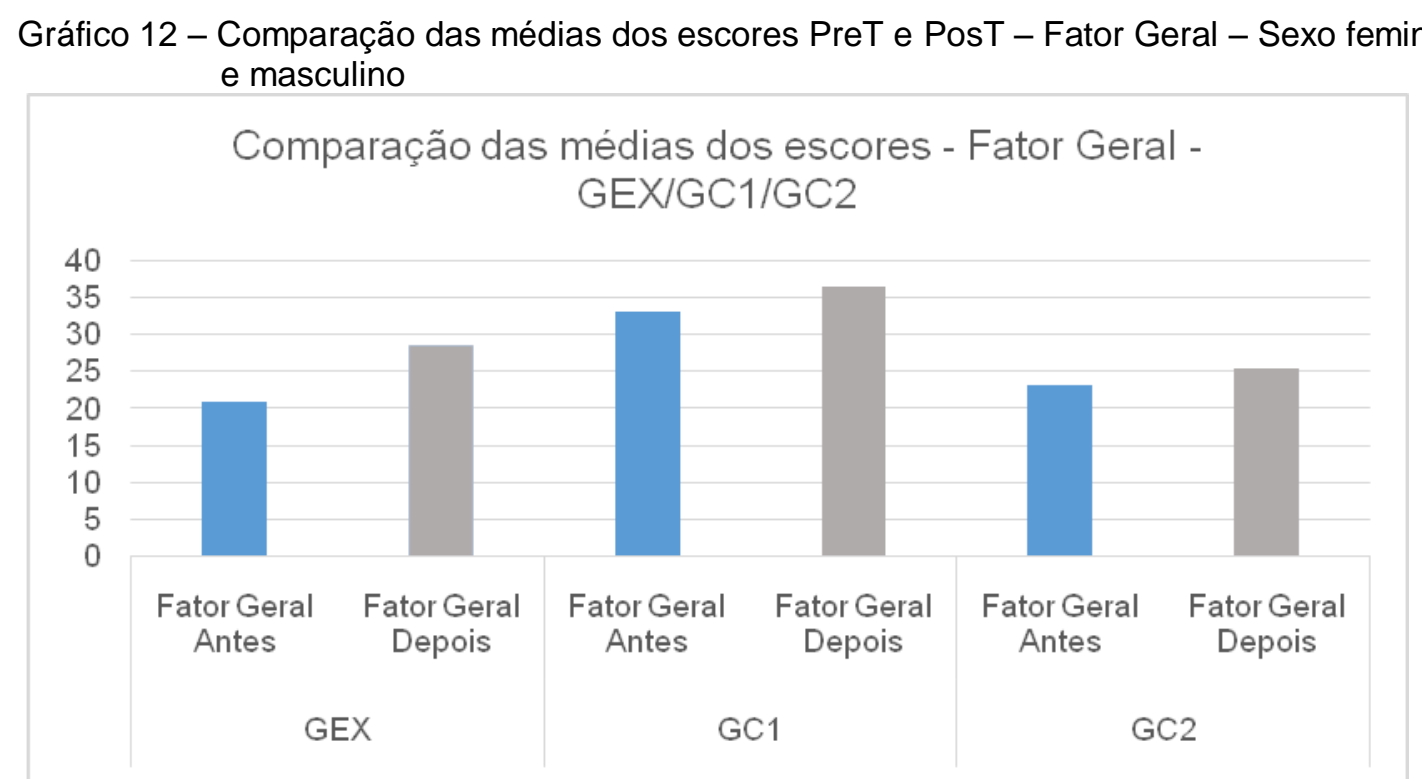

Fonte: Elaborado a partir dos dados obtidos no teste.

É possível ver que os ganhos do GEX foram superiores aos ganhos dos demais grupos. O GEX apresentou um ganho de 7,67 pontos entre o PreT e o PosT, enquanto o GC1 e o GC2 apresentaram ganhos de 3,33 e 2,08, respectivamente. Dessa forma, foi possível observar uma tendência no comportamento dos dados, já que o GEX apresentou ganhos superiores aos demais grupos, como podemos ver no gráfico a seguir: 


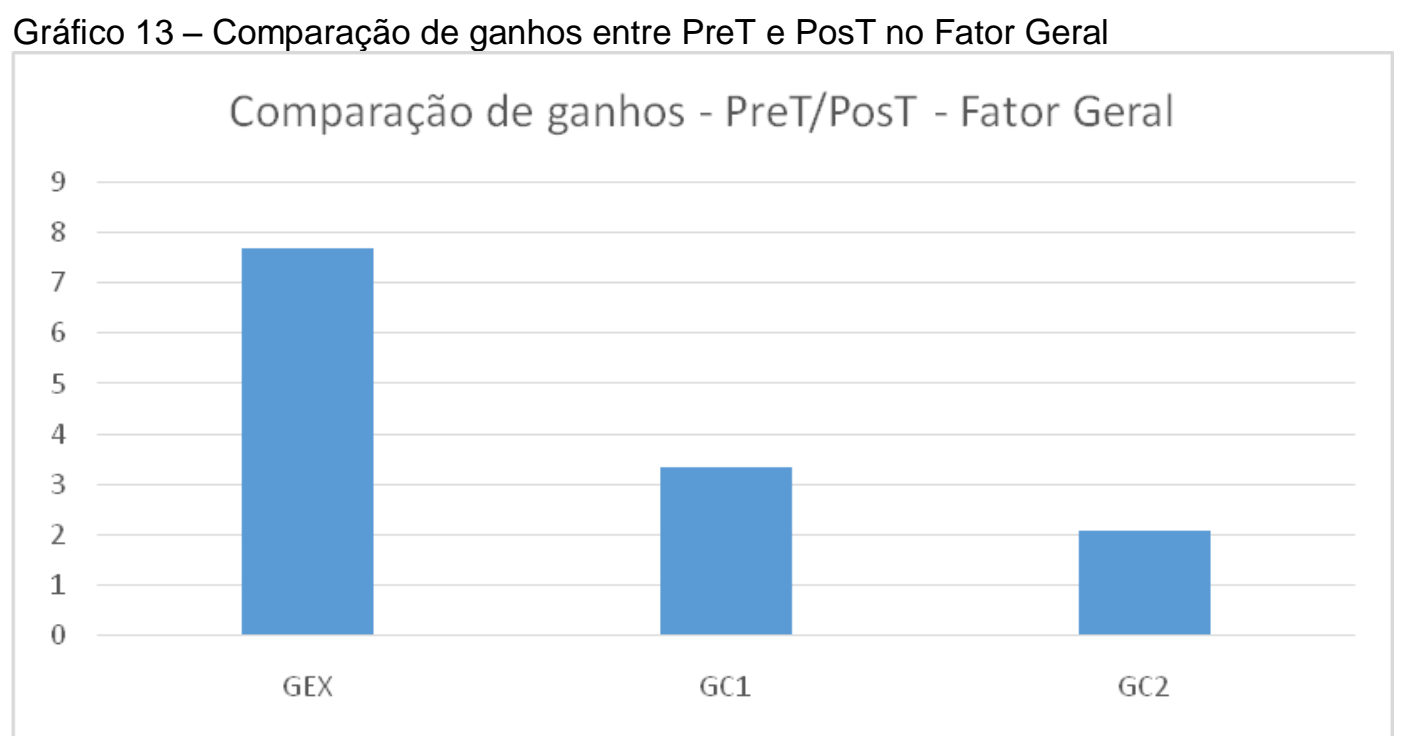

Fonte: Elaborado a partir dos dados obtidos no teste.

Porém, tais ganhos não foram suficientes para representar dados estatisticamente significativos, quando comparados os três grupos simultaneamente, indicando que a prática do xadrez é responsável por maiores ganhos nos índices de raciocínio do que aulas de reforço ou da ausência de atividades extras. Foi observada uma tendência de ganho maior do GEX em relação aos demais grupos. Dessa forma, analisando tais dados, a hipótese não pode ser rejeitada, pois o GEX apresentou ganhos superiores aos demais grupos, ou seja, a resposta para a pergunta que intitula o capítulo é sim.

Entretanto, se observarmos friamente os resultados, juntamente com a discussão entre artigos e estudos semelhantes, a resposta para tal pergunta é não. Porém, não podemos encarar tais resultados como provas irrefutáveis da inutilidade do xadrez no desenvolvimento de habilidades cognitivas. Conceição (2008) afirmou que devemos ser cautelosos ao analisar estudos que envolvam pesquisas experimentais com objetos sociais (tais como pessoas, grupos ou instituições) e análises estatísticas. Em seu artigo intitulado "Leitura crítica dos dados estatísticos em trabalhos científicos", ele busca apresentar uma revisão de conceitos relacionados aos cálculos estatísticos que são fundamentais para a leitura e pensamento críticos diante da literatura científica.

Mesmo que resultados altamente significantes, estatisticamente falando, sejam encontrados, podemos apenas nos ater a sugerir uma tendência de comportamento, ao invés de inferir resultados absolutos. O mesmo pode-se dizer quando a situação se inverte (CONCEIÇÃO, 2008). 
Obter um valor $p>0,05$ não significa a ausência de um efeito; talvez signifique apenas que os dados foram insuficientes para estabelecer uma correlação estatisticamente significante entre a atividade e o efeito esperado.

[...] Ora, o valor de $p>0,05$ "sem diferença estatística significativa" sugere a falta de evidência de um efeito. Quando se lê "não houve diferença estatística entre os dois grupos" está-se diante de informação incompleta. O grande valor para $p$ a rigor não significa ausência de efeito como erroneamente os autores concluíram [...] (CONCEIÇÃO, 2008, p. 261).

O autor reconheceu os desafios e complexidades em se estudar fenômenos ou a influência de tratamentos e intervenções sobre indivíduos. Um dos pontos mais complexos se refere ao tamanho da amostra. Tanto amostras pequenas como muito grandes podem "mascarar" os resultados. É plenamente plausível se pensar que não houve diferenças estatisticamente significantes entre o GEX, GC1 e GC2 compostos por 12 indivíduos cada. Mas resultados diferentes poderiam ser encontrados caso os grupos fossem compostos por 15 indivíduos.

\footnotetext{
Como seria inviável estudar todos os indivíduos atingidos pelo mesmo fenômeno, se retira dessa população um grupo de indivíduos que passarão a representá-la. A isso, chama-se amostra. Inúmeras vezes, p é maior do que 0,05 , simplesmente porque o número de indivíduos estudados (amostra) é muito pequeno (CONCEIÇÃO, 2008, p. 261).
}

Isso auxilia no pensamento crítico e também a enxergar possibilidades de estudos futuros mais aprofundados que sejam capazes de encontrar dados suficientes para elucidar com maior precisão e fidedignidade os fenômenos estudados.

Outro ponto que pode ter sido determinante sobre os resultados se refere ao tempo de intervenção. Apesar de ser constituído de regras claras e bem definidas, o jogo de xadrez é complexo, exigindo um esforço grande para compreender todas as regras e aplicá-las na prática, principalmente para crianças em início de escolarização em uma zona rural. Muitas das crianças ainda cometiam erros relativos a regras básicas, mesmo no final do período de intervenção no GEX. Isso não reflete, necessariamente, incapacidade do professor em ensinar nem muito menos incapacidade do aluno em aprender, mas sim do pouco tempo destinado ao ensino e prática do jogo. Estudos dessa natureza costumam ter períodos de intervenção mais longos, como o de Fergusson (1988), com duração de 8 meses, ou até mesmo o de Fried e Ginsburg [1985?], com duração de 18 semanas. Apesar de 
ser um tempo considerável de aula, uma hora pode ser pouco para algumas crianças assimilarem bem os conteúdos apresentados, bem como praticá-los. Macedo (2005, p. 18) citou esse ponto ao falar sobre dificuldades apresentadas por crianças diante de certas tarefas escolares: "O fato é que muitas tarefas escolares, do modo como são propostas, são desagradáveis para as crianças. Algumas razões para isso é que o tempo de sua realização é excessivo ou insuficiente".

Porém, esse é um fato que pode ser levado em consideração na defesa da prática do xadrez em ambientes escolares. Mesmo em uma turma heterogênea, em se falando de ritmo de aprendizagem do jogo, foi possível conduzir atividades que se adequassem ao ritmo de cada aluno. Ou seja, alunos com maior facilidade em assimilar as regras e conteúdos foram sendo constantemente desafiados com atividades mais complexas, assim que terminaram as mais simples. Enquanto isso, na mesma sala, alunos com maior dificuldade eram auxiliados pelo professor na realização de tarefas simples sobre regras básicas. Cada aluno se desenvolvia no seu ritmo, sem que a dificuldade de um prejudicasse o desempenho de outro. Contudo, o tempo total de intervenção talvez não tenha sido o suficiente para que os benefícios do xadrez para com o raciocínio fossem melhor explorados e desenvolvidos. Mesmo com o tempo total de intervenção reduzido, foi possível observar, analisando os dados obtidos, que há uma tendência positiva entre a prática do xadrez e o desenvolvimento do raciocínio, pois os ganhos obtidos pelo GEX foram superiores aos dos demais grupos, mesmo não obtendo um $p<0,05$. Isso mostra como o tempo de intervenção pode ter sido um dos fatores determinantes para o resultado do estudo, e também para a obtenção de dados mais promissores em estudos futuros. 


\title{
6 CONSIDERAÇÕES FINAIS
}

Não apenas o senso comum, mas a comunidade científica, em suas mais variadas áreas de concentração, concordam com o fato de que o xadrez auxilia na aquisição e aprimoramento de habilidades imprescindíveis ao desenvolvimento humano. Desde Binet (1984) até Campitelli e Gobet (2007), são constantes e contundentes os estudos que obtém conclusões robustas sobre benefícios cognitivos, sociais e emocionais do xadrez. Porém, muito chão ainda há a se percorrer, pois existe uma parcela da população que, descrente, credita ao xadrez o rótulo de atividade frívola.

Porém, não podemos recriminar aqueles que assim creem que o xadrez é apenas um passatempo. Como exemplo, posso citar o grande escritor Millôr Fernandes, um dos mais inteligentes e sagazes da literatura brasileira, principalmente quando falamos de humor. Ao falar sobre xadrez, além da carta direcionada a Mequinho, grande mestre de xadrez, citada no capítulo "Por que o xadrez nas escolas?", Millôr disse que o xadrez é um "Jogo chinês que aumenta a capacidade de jogar xadrez". Até mesmo os professores e cientistas que estudam xadrez concordam com os problemas encontrados ao se busca comprovar os benefícios do jogo para o ser humano. Silva (2010, p. 217), ao concluir seu estudo, afirmou que:

\begin{abstract}
Não obstante, conforme foi visto, a maioria dos estudos sobre o xadrez escolar carece de suporte empírico, e os que apresentam suporte empírico possuem graves problemas metodológicos. Entretanto, mestres e professores de xadrez têm plena convicção dos benefícios das aulas de xadrez, propondo que o xadrez desenvolve, dentre outras coisas, a inteligência geral, a habilidade para concentração, fortalece o ego, 0 autocontrole, a habilidade para análise, e a habilidade para leitura.
\end{abstract}

Ciente dos graves problemas metodológicos e suporte empírico, busquei as recomendações de Campitelli e Gobet (2007), que apontaram problemas metodológicos em inúmeras pesquisas sobre os benefícios do xadrez, mas também buscaram direcionar pesquisas futuras, indicando os caminhos a serem trilhados que auxiliariam no preenchimento de lacunas deixadas por estudos anteriores.

Em busca de fortalecer esse caminho por muitos trilhado anteriormente e preencher as lacunas apresentadas por diversas pesquisas, o presente estudo teve por objetivo mostrar se o xadrez é fator influente nos ganhos de raciocínio, 
habilidade cognitiva tão requisitada nos mais diversos ambientes e situações, seja no âmbito acadêmico, social ou emocional. Como resultado, foi possível observar que o xadrez demonstrou a tendência de ser uma ferramenta pedagógica mais poderosa do que atividades de reforço escolar, comumente utilizadas nas escolas pelo mundo. Com isso, foi possível sugerir que a prática do xadrez apresenta influência positiva no desenvolvimento do raciocínio, fortalecendo, assim, os resultados de estudos anteriores que mostraram os benefícios do xadrez em habilidades cognitivas.

Porém, mesmo com a confirmação dessa tendência, os ganhos obtidos no grupo que praticou xadrez não foram estatisticamente diferentes dos ganhos obtidos no grupo que frequentou aulas de reforço e no grupo que não frequentou atividades extracurriculares, quando comparados conjuntamente. Isso expõe as limitações do estudo, fundadas principalmente no pouco tempo de intervenção, bem como no reduzido número de indivíduos que constituíam os grupos estudados.

Os resultados obtidos nos auxiliam a enxergar possibilidades de estudos futuros mais aprofundados que sejam capazes de encontrar dados suficientes para elucidar com maior precisão e fidedignidade os fenômenos estudados. Dessa forma, recomendam-se novas investigações que se utilizem dos mesmos instrumentos, métodos e procedimentos do presente estudo, mas utilizando amostras maiores e multicêntricas, combinando dados de diferentes locais. Ou então, até mesmo utilizando-se de jogos que envolvam o raciocínio de forma semelhante ao xadrez. Além disso, o tempo de intervenção deve ser maior, de no mínimo um ano, para que seja possível a compreensão completa dos alunos sobre as regras básicas do xadrez. Dessa forma, é possível confirmar com maior certeza que os alunos foram avaliados após usufruir dos benefícios do xadrez de forma plena, conhecendo plenamente as regras básicas e transcendendo-as ao ponto de formular táticas e estratégias próprias, utilizando da criatividade e desenvolvendo profundamente 0 raciocínio.

Contudo, essas limitações não minimizam os benefícios do presente estudo em sugerir a necessidade da inclusão de atividades que busquem desenvolver o raciocínio de forma lúdica e desafiadora, como é o caso do xadrez. Estudos como este nos põem a refletir sobre a questão: Será que obteremos melhores resultados utilizando todo o tempo que temos em sala de aula com atividades conteudistas ou devemos dar mais espaço para jogos, brincadeiras e atividades lúdicas? 


\section{REFERÊNCIAS}

ARTHUR, W. Brian. Inductive reasoning and bounded rationality: the El Farol problem. American Econonomic Review (Papers and Proceedings), Stanford, v. 84, n. 2, p. 406-411, mai. 1994.

BILALIC, M. et al. Why are (the best) women so good at chess? Participation rates and gender diferences in intellectual domains. Proceedings of the Royal Society B: Biological Sciences 276, p. 1161-1165, mar. 2009.

BINET, A. Psychologie des Grands Calculateurs et Joueurs d'Echecs. Paris: Hachette, 1894.

BRASIL. [Lei de Diretrizes e Bases Nacional (1996)]. LDB: Lei de Diretrizes e Bases da Educação Nacional: Lei no 9.394/1996. ed. atualizada. Brasília: Edições Câmara, 2010.

BRASIL. Secretaria de Educação Fundamental. Parâmetros curriculares nacionais: introdução aos parâmetros curriculares nacionais / Secretaria de Educação Fundamental. - Brasília: MEC/SEF, 1997.

BROUGÈRE, Gilles. Jogo e educação. Porto Alegre: Artes Médicas, 1998.

BUSSAB, W. O.; MORETTIN, P. A. Estatística Básica. 6. ed. São Paulo: Saraiva, 2010.

BUTMAN, Judith; ALLEGRI, Ricardo F. A cognição e o córtex cerebral. Psicologia: Reflexão e Crítica, Porto Alegre: v. 14, n. 2, p. 275-279, jun. 2001.

CAMPITELLI, Guillermo; GOBET, Fernand. Educational benefits of chess instruction: a critical review. T. Redman, Education and chess, 2005.

- Uma revisão crítica sobre os benefícios educativos da instrução enxadrística. In: FILGUTH, Rubens (Org.). A importância do xadrez. Porto Alegre: Artmed, 2007. p. 183-197.

CAMPOS, Maria Célia Rabello Malta; MACEDO, Lino de. Desenvolvimento da função mediadora do professor em oficinas de jogos. Psicologia Escolar e Educacional, Maringá, v. 15, n. 2, dez. 2011.

CAPABLANCA, José Raúl. Lições elementares de xadrez. Curitiba: Hemus, 2002.

CHARNESS, N.; KRAMPE, R.; MAYR, U. The role of practice and coaching in entrepreneurial skill domains: an international comparison of life-span Chess skill acquisition. In: ERICSSON, K. A. The road to excellence: the acquisition of expert performance in the arts and sciences, sports and games. New Jersey: Ed. K. A. Ericsson, 1996, p. 51-80. 
CHRISTOFOLETTI, D. F. A. O xadrez nos contextos do lazer, da escola e profissional: aspectos psicológicos e didáticos. $154 \mathrm{f}$. Dissertação (Mestrado em Ciências da Motricidade) - Universidade Estadual Paulista, UNESP, Instituto de Biociências, 2007.

CONCEIÇÃO, Mário J. da. Leitura Crítica dos Dados Estatísticos em Trabalhos Científicos. Revista Brasileira de Anestesiologia, Campinas: v. 58, n. 3, maio/jun. 2008.

DAMASIO, Antônio R. Descartes' Error: Emotion, Reason, and the Human Brain. Grosset/Putnam Book, New York, 1994.

DAUVERGNE, Peter. O caso do xadrez como ferramenta para desenvolver as mentes de nossas crianças. In: FILGUTH, Rubens (Org.). A importância do xadrez. Porto Alegre: Artmed, 2007. p. 11-17.

DAVIS, M. Folk music psychology. The Psychologist, United Kingdom: v. 7, n. 12, p. 537, mar. 1994.

DELGADO, A. C. C.; MULLER, F. Em busca de metodologias investigativas com as crianças e suas culturas. Cadernos de Pesquisa (Fundação Carlos Chagas), São Paulo, v. 35, n. 125, p. 161-179, mai/ago. 2005.

DEWEY, John. Como Pensamos. São Paulo: Companhia Editora Nacional, 1959.

DE GROOT, Adriaan. Thought and choice in chess. 2. ed. Cambridge: Mouton Publishers, 1978.

DOYLE, Arthur C. A scandal in Bohemia. The Strand Magazine, UK, p. 3-13, jan. 1891.

. O signo dos quatro. São Paulo: Rideel, 2002.

ERICSSON, K. A. The road to excellence: the acquisition of expert performance in the arts and sciences, sports and games. New Jersey: Ed. K. A. Ericsson, 1996.

ERICSSON, K. A.; KRAMPE, R.; TESCH-ROMER, C. The role of deliberate practice in the acquisition of expert performance. Psychological Review, Pittsburgh: v. 100, n. 3, p. 363-406, 1993.

FERGUSON, Robert. The USA Junior Chess Olympics Research: Developing Memory and Verbal Reasoning. New Horizons for Learning, abr. 2001. Disponível em:

<education.jhu.edu/PD/newhorizons/Neurosciences/articles/USA\%20Junior\%20Ches s\%20Olympics\%20Research/>. Acesso em: 12 nov. 2014.

FERNANDES, M. O livro vermelho dos pensamentos de Millôr. 1. ed. Porto Alegre: L\&PM Editores, 2005.

FILGUTH, Rubens (Org.). A importância do xadrez. Porto Alegre: Artmed, 2007. 
FREIRE, João Batista et al. Iniciação Esportiva. Brasília: Universidade de Brasília, Centro de Educação a Distância, 2005.

FRIED, Steven; GINSBURG, Norman. The Effect of Learning to Play Chess on Cognitive, Perceptual and Emotional Development in Children. Unpublished Paper, [1985?].

GARCIA, Melquisedek Aguiar. O xadrez no contexto escolar: pesquis-ação com estudantes do ensino fundamental. 184 f. Dissertação (Mestrado em Educação) Faculdade de Educação - Universidade de Brasília, Brasília, 2011.

GIL, Antônio Carlos. Como elaborar projetos de pesquisa. 4. ed. São Paulo: Atlas, 2002.

GOBET, Fernand; De VOOGT, Alex; RETSCHITZKI, Jean. Moves in mind: the psychology of board games. Hove, UK: Psychology Press, 2004.

HILL, Bem; TOSTADO, Kevin. Knight's Tours. Olin College of Engineering, Needham, Massachussetts, p. 1-11, dez. 2004.

HUIZINGA, Johan. Homo Ludens. 7. ed. São Paulo: Perspectiva, 2012.

JÔ SOARES entrevista Garry Kasparov [2011]. Disponível em: <https://www.youtube.com/watch?v=_3-C98Ekops>. Acesso em: 16 nov. 2013.

KAMII, Constance; DEVRIES, Rheta. Jogos em grupo na educação infantil: implicações na teoria de Piaget. Prefácio: Jean Piaget. Trad.: Marina Célia Dias Carrasqueira. 2 ed. Porto Alegre: Artmed, 2009.

KASPAROV'S CALCULATIONS - Mindboggling!!! (very instructive). [1990?]. Disponível em: <https://www.youtube.com/watch?v=SMe-hvCwTRo>. Acesso em: 16 nov. 2013.

KRUK, R., SEIRAWAN, Y. REERINK, H. Dame Aan Zet. Queen's move. Koninklijke Bibliotheek. Den Haag, 2000.

LASKER, Edward. História do xadrez. 2. ed. São Paulo: Ibrasa, 1999.

LASKER, Emanuel. Lasker's Manual of Chess. Milford: Russel Enterprises, 2008.

MACEDO, L., PASSOS, N.C. Os jogos e o lúdico na aprendizagem escolar. 1. ed. Porto Alegre: artmed, 2005.

MAYER, Richard E. What Causes Individual Differences in Cognitive Performance? In: STERNBERG, R. J.; GRIGORENKO, E. L. (Orgs.). The psychology of abilities, competencies, and expertise, Cambridge University Press, Cambridge, 2003. p. 263-273.

MONTGOMERY, Douglas C. Design and Analysis of Experiments. New York: Jonh Wiley \& Sons, 2001. 
MULLER, Fernanda. Socialização na escola: transições, aprendizagem e amizade na visão das Crianças. Educar em revista, Curitiba, n. 32, p. 123-141, abr. 2008.

OLIVA, A. D. et. al. Razão, emoção e ação em cena: a mente sob um olhar evolucionista. Psicologia: teoria e pesquisa. Brasília: v. 22, n. 1, jan/abr. 2006.

PASQUALI, Luiz. TNVRI: manual técnico e de aplicação. São Paulo: Vetor, 2005.

PETROSIAN, Tigran. Tigran Petrosian's best games. [1981?] Disponível em: <http://www.chessgames.com/perl/chesscollection?cid=1014968>. Acesso em: 16 nov. 2013.

RODRIGUES, Andreia Souza Figueiredo. Relação entre a prática do jogo de xadrez e o desempenho escolar: um estudo de caso. $99 \mathrm{f}$. Monografia (Pós Graduação em Ensino na Educação Básica) - Faculdade de Educação Universidade Federal do Espírito Santo, Espírito Santo, 2013.

SÁ, Antônio Villar Marques de. Ensino enxadrístico em contexto escolar, periescolar e extraescolar: experiências em instituições educativas na França e suas repercussões. In: SILVA, Wilson (Org.). Xadrez e educação: contribuições da ciência para o uso do jogo como instrumento pedagógico. Curitiba: UFPR, 2012. p. 169-190.

; REZENDE JÚNIOR, Luiz Nolasco de; MELO, Wellington Aguiar. Benefícios lúdicos e pedagógicos do xadrez. In: SÁ, Antônio Villar Marques de; SILVA, Américo Júnior Nunes; BRAGA, Maria Dalvirene; SILVA, Onã (Orgs.). Ludicidade e suas interfaces. Brasília: Liber Livro, 2013. p. 265-281.

SEARCHING for Bobby Fischer. Produção: Scott Rudin, Direção: Steven Zaillian. Hollywood, CA: Paramount, 1993. DVD (109 min), Ntsc, son., color. Legendado. Port.

SILVA, Leomagon Rodrigues da. Contribuições do xadrez para o ensinoaprendizagem de matemática. 174 f. Dissertação (Mestrado em Educação) Faculdade de Educação - Universidade de Brasília, Brasília, 2010.

SILVA, Wilson da. Raciocínio lógico e o jogo de xadrez: em busca de relações. 578 f. Tese (Doutorado em Educação) - Faculdade de Educação - Universidade Estadual de Campinas, Campinas, 2010.

SLOBODA, John A. The acquisition of musical performance expertise: Desconstructing the "Talent" account of individual differences in musical expressivity. In: ERICSSON, K. A. The road to excellence: the acquisition of expert performance in the arts and sciences, sports and games. New Jersey: Ed. K. A. Ericsson, 1996. p. 107-126.

SOUZA, Rosa C. F. de. Discurso dos educadores frente às manifestações emocionais de crianças da educação infantil. Revista Electrónica de Investigación y Docencia (REID), Florianópolis: v. 9, n. 1, p. 23-37, jan. 2013. 
STERNBERG, Robert J. Psicologia cognitiva. 5. ed. São Paulo: Cengage Learning, 2010.

THORNDIKE, Edward Lee; WOODWORTH, Robert Sessions. The influence of improvement in one mental function upon the efficiency of other functions. Psychological Review, Pittsburgh, v. 8, n. 4, p. 384-395, jul. 1901.

VIGOTSKI, Lev Semyonovich. A formação social da mente. 7. ed. São Paulo: Martins Fontes, 2007.

WEIL, Pierre. Manual de psicologia aplicada. Trad. Ângela Biaggio e Luís Natalício: 2. ed. Belo Horizonte: Itatiaia, 1967.

VELOSO-SILVA, R. R.; SÁ, A. V. M. de. Práticas pedagógicas no ensinoaprendizado do jogo de xadrez em escolas de Montes Claros, Minas Gerais. In: SILVA, W. da (Org.). Xadrez e educação: contribuições da ciência para o uso do jogo como instrumento pedagógico. Curitiba: EdUFPR, 2012. p. 275-298.

WECHSLER, D. Manual for the Wechsler Intelligence Scale for Children Revised. New York: Psychological Corporation, 1974. Disponível em: $<$ http://images.pearsonclinical.com/images/NR/matrix.jpgs. Acesso em: $10 \mathrm{dez}$. 2014. 


\section{APÊNDICE}

\section{APÊNDICE A - Planejamento das 20 aulas de 60 min. cada e da competição, destinadas ao GEX.}

\begin{tabular}{|c|c|c|c|c|}
\hline Data & Objetivos & Procedimentos & Interferências & Prática \\
\hline - Aula 1 & $\begin{array}{l}\text { - Apresentar ao } \\
\text { aluno a sala } \\
\text { de aula, } \\
\text { recursos e } \\
\text { professor. } \\
\text { - Conhecer as } \\
\text { peças. }\end{array}$ & $\begin{array}{l}\text { - Apresentação do } \\
\text { professor em sala de } \\
\text { aula. } \\
\text { - Formar uma fila e de } \\
\text { forma organizada } \\
\text { dirigir-se à sala de } \\
\text { xadrez. } \\
\text { - Apresentar a sala de } \\
\text { aula e seus recursos. } \\
\text { - Expor e discutir os } \\
\text { combinados. }\end{array}$ & $\begin{array}{l}\text { - Quem sabe jogar Xadrez? } \\
\text { - Onde você aprendeu a jogar } \\
\text { xadrez? } \\
\text { - Quantos anos você tinha quando } \\
\text { aprendeu a jogar xadrez? } \\
\text { - Quais os nomes das peças? } \\
\text { - Quantas peças diferentes } \\
\text { existem? } \\
\text { - Quantas peças existem em um } \\
\text { tabuleiro? Quantas são brancas? } \\
\text { Quantas são pretas? }\end{array}$ & $\begin{array}{l}\text { - Permitir que alguns } \\
\text { alunos exponham } \\
\text { seus conhecimentos } \\
\text { enxadrísticos pré- } \\
\text { adquiridos. }\end{array}$ \\
\hline - Aula 2 & $\begin{array}{l}\text { - Apresentar ao } \\
\text { aluno a sala } \\
\text { de aula, } \\
\text { recursos e } \\
\text { professor. } \\
\text { - Contar a } \\
\text { história do } \\
\text { xadrez. }\end{array}$ & $\begin{array}{l}\text { - História do xadrez. } \\
\text { - Lenda grãos de arroz. }\end{array}$ & $\begin{array}{l}\text { - Quem sabe jogar xadrez? } \\
\text { - Onde você aprendeu a jogar } \\
\text { xadrez? } \\
\text { - Quantos anos você tinha quando } \\
\text { aprendeu a jogar xadrez? } \\
\text { - Onde o xadrez foi inventado? } \\
\text { Quem inventou? } \\
\text { - Há quanto tempo o xadrez } \\
\text { existe? }\end{array}$ & $\begin{array}{l}\text { - Pedir aos alunos que } \\
\text { formulem estimativas } \\
\text { sobre o ano em que } \\
\text { o xadrez foi } \\
\text { inventado. }\end{array}$ \\
\hline - Aula 3 & $\begin{array}{l}\text { - Introduzir o } \\
\text { que é } \\
\text { movimento e } \\
\text { captura. } \\
\text { - Introduzir a } \\
\text { movimentação } \\
\text { e captura do } \\
\text { peão. } \\
\text { - Introduzir } \\
\text { conhecimento } \\
\text { sobre casas, } \\
\text { colunas, } \\
\text { fileiras e } \\
\text { diagonais. }\end{array}$ & $\begin{array}{l}\text { - Explicar o que é o } \\
\text { tabuleiro, o que são } \\
\text { casas, fileiras, colunas } \\
\text { e diagonais. } \\
\text { - Explicar o que é } \\
\text { movimento e captura. } \\
\text { - Explicar a diferença } \\
\text { entre horizontal e } \\
\text { vertical (história do } \\
\text { horizonte). } \\
\text { - Explicar sobre } \\
\text { movimentação so e } \\
\text { captura do peão. }\end{array}$ & $\begin{array}{l}\text { - O que são casas? } \\
\text { - Coluna e fileira ficam em que } \\
\text { direção? } \\
\text { - Qual a maior diagonal do } \\
\text { tabuleiro? } \\
\text { - Por que o centro do tabuleiro é } \\
\text { importante? } \\
\text { - O tabuleiro tem quantas casas? } \\
\text { - O tabuleiro tem quantas fileiras? } \\
\text { - O tabuleiro tem quantas colunas? } \\
\text { - O tabuleiro tem quantas } \\
\text { diagonais? } \\
\text { - Existem quantas peças brancas? } \\
\text { e preta? } \\
\text { - Somando as duas cores qual é o } \\
\text { resultado? } \\
\text { - O tabuleiro tem } 64 \text { casas. } \\
\text { Diminuindo } 16 \text { peças qual é o } \\
\text { resultado? } \\
\text { - O que é movimento? E captura? } \\
\text { - Que direção o peão anda? } \\
\text { - Que direção o peão captura? }\end{array}$ & $\begin{array}{l}\text { - Vivo ou morto xadrez } \\
1 \text { individual (VMX). }\end{array}$ \\
\hline - Aula 4 & $\begin{array}{l}\text { - Rever e } \\
\text { praticar } \\
\text { movimentação } \\
\text { e captura de } \\
\text { peão. } \\
\text { - Aprender } \\
\text { movimentos } \\
\text { especiais de } \\
\text { Peões. }\end{array}$ & $\begin{array}{l}\text { - } \text { Apresentar vídeo } \\
\text { "Check Mate". } \\
\text { - Rever movimentação e } \\
\text { captura do peão. } \\
\text { - Introduzir poderes } \\
\text { especiais do peão } \\
\text { (movimentação dupla e } \\
\text { promoção). }\end{array}$ & $\begin{array}{l}\text { - Que direção o peão se } \\
\text { movimenta? } \\
\text { - Que direção ele captura? } \\
\text { - Peão pode voltar? } \\
\text { - Quantas casas o peão pode se } \\
\text { movimentar? } \\
\text { - Após o primeiro lance, o peão } \\
\text { pode se movimentar duas casas? } \\
\text { - O peão pode se transformar em } \\
\text { qualquer peça ao chegar à última } \\
\text { fileira? } \\
\text { - O peão pode ser promovido a } \\
\text { uma peça que não foi capturada? }\end{array}$ & $\begin{array}{l}\text { - Bloqueio Captura: } \\
\text { alunos sentados em } \\
\text { volta do tabuleiro } \\
\text { gigante. Professor } \\
\text { coloca um peão em } \\
\text { uma casa. Ao } \\
\text { chamar o nome de } \\
\text { um aluno, fala-se } \\
\text { BLOQUEIO ou } \\
\text { CAPTURA, devendo } \\
\text { o aluno bloquear ou } \\
\text { capturar. }\end{array}$ \\
\hline
\end{tabular}




\begin{tabular}{|c|c|c|c|c|}
\hline - Aula 5 & $\begin{array}{l}\text { - Rever } \\
\text { praticar } \\
\text { movimentação } \\
\text { e captura de } \\
\text { peão. } \\
\text { - Iniciar tática e } \\
\text { estratégia } \\
\text { básica. }\end{array}$ & $\begin{array}{l}\text { - Rever movimentação e } \\
\text { captura do peão. } \\
\text { - Rever poderes } \\
\text { especiais. } \\
\text { - Verificar alunos com } \\
\text { dificuldade e procurar } \\
\text { sanar dúvidas gerais. } \\
\text { - Reforçar diferença } \\
\text { entre captura e } \\
\text { movimentação. }\end{array}$ & $\begin{array}{l}\text { - Existe diferença entre os peões? } \\
\text { - O que é melhor, um peão } \\
\text { - sozinho ou vários peões juntos? } \\
\text { Que peões devem ser movidos } \\
\text { primeiro, os do centro ou os da } \\
\text { borda? } \\
\text { - É melhor atacar uma peça } \\
\text { protegida ou uma desprotegida? } \\
\text { - Um peão prestes a ser } \\
\text { promovido é melhor que um peão } \\
\text { que ainda não se moveu? }\end{array}$ & - Vmx por equipes. \\
\hline - Aula 6 & $\begin{array}{l}\text { - Aprender } \\
\text { movimentação } \\
\text { e captura da } \\
\text { torre. }\end{array}$ & $\begin{array}{l}\text { - Explicar sobre a } \\
\text { movimentação e e } \\
\text { captura com a torre. } \\
\text { - História da torre, } \\
\text { castelos e arqueiro. } \\
\text { - Explicar diferenças } \\
\text { entre movimentação e } \\
\text { captura da torre e do } \\
\text { peão. }\end{array}$ & $\begin{array}{l}\text { - Em que direção a torre se } \\
\text { movimenta? } \\
\text { - Em que direção a torre captura? } \\
\text { - Quem é melhor, uma torre ou um } \\
\text { peão? } \\
\text { - Quantas casas a torre se } \\
\text { movimenta? } \\
\text { - Torre pode voltar? } \\
\text { - Quantas peças a torre pode } \\
\text { capturar de cada vez? }\end{array}$ & $\begin{array}{l}\text { - Torre Maluca: alunos } \\
\text { em volta do tabuleiro } \\
\text { gigante, sentados. } \\
\text { Professor coloca duas } \\
\text { peças no tabuleiro, e, } \\
\text { ao chamar o nome de } \\
\text { um aluno, este deve } \\
\text { se posicionar de } \\
\text { forma a atacar as } \\
\text { duas peças, } \\
\text { representando uma } \\
\text { torre. }\end{array}$ \\
\hline
\end{tabular}

\begin{tabular}{|c|c|c|c|}
\hline $\begin{array}{l}\text { - Aprender } \\
\text { movimentação } \\
\text { e captura do } \\
\text { Bispo. }\end{array}$ & $\begin{array}{l}\text { - Explicar sobre } \\
\text { movimentação } \\
\text { captura com o Bispo. } \\
\text { - Explicar diferenças } \\
\text { entre movimentação e } \\
\text { captura entre as peças } \\
\text { já estudadas. }\end{array}$ & $\begin{array}{l}\text { - Em que direção o bispo se } \\
\text { movimenta? } \\
\text { - Em que direção o bispo captura? } \\
\text { - Quem é melhor, uma torre, um } \\
\text { bispo ou um peão? } \\
\text { - Quantas casas o Bispo se } \\
\text { movimenta? } \\
\text { - Bispo pode voltar? } \\
\text { - Quantas peças o Bispo pode } \\
\text { capturar de cada vez? }\end{array}$ & $\begin{array}{l}\text { - Bispo Maluco: alunos } \\
\text { em volta do tabuleiro } \\
\text { gigante, sentados. } \\
\text { Professor coloca } \\
\text { duas peças no } \\
\text { tabuleiro, e, ao } \\
\text { chamar o nome de } \\
\text { um aluno, este deve } \\
\text { se posicionar de } \\
\text { forma a atacar as } \\
\text { duas peças, } \\
\text { representando um } \\
\text { Bispo. }\end{array}$ \\
\hline
\end{tabular}

$\begin{array}{ll}\text { - Aprender } & \text { Explicar sobre a } \\ \text { movimentação } & \text { movimentação } \\ \text { e captura da } & \text { captura com a dama. } \\ \text { dama. } & \text { Explicar diferenças } \\ & \text { entre movimentação e } \\ \text { captura entre as peças } & \text { já estudadas. } \\ & \text { - Ressaltar a importância } \\ & \text { e força da dama. } \\ \text { - Salientar a semelhança } & \\ \text { de movimentação da } \\ \text { dama com bispo e } \\ \text { torre. }\end{array}$

- Que peças, juntas, formam a - Dama Louca: alunos movimentação da dama?

- Qual foi a peça mais forte vista até agora? E a segunda mais forte? E a terceira?

- Por que se deve tomar cuidado ao movimentar a dama?

- Aula 8

- Quanto vale a dama?

- Quantos peões eu preciso ter para chegar ao valor da dama? E quantos bispos? E cavalos? sentados em círculo em volta do tabuleiro gigante, com pernas cruzadas.

professor chama dois nomes, e ambos têm que ficar em pé em uma casa do tabuleiro, representando Damas, mas um não pode estar atacando o outro.

$\begin{array}{lrl}\text { - Aprender } & \text { - Explicar sobre a } \\ \text { movimentação } & \text { movimentação } \\ \text { e captura do } & \text { captura com o cavalo. } \\ \text { cavalo. } & \text { - Explicar diferenças } \\ & \text { entre movimentação e } \\ & \text { captura entre as peças } \\ & \text { já estudadas. } \\ & \text { - Ressaltar a importância } \\ & \text { e força do cavalo } \\ & \text { contra Dama. } \\ \text { - Salientar a habilidade } & \text { de salto do cavalo, } \\ & \text { explicando } \text { a } \\ & \text { movimentação sobre } \\ & \text { as peças e e } \\ & \text { demonstrando erros } \\ & \text { comuns cometidos. }\end{array}$

- Como o cavalo se movimenta?

- O cavalo pode pular qualquer peça?

- O cavalo captura quem ele pula?

- Contra quem o cavalo é mais forte?

- O cavalo tem o mesmo valor de outra peça, que peça é essa?

- Quantas peças o cavalo pode capturar de cada vez? Se ele pular sobre três peças diferentes, qual delas ele captura?
- Jogo Cavalo Rápido alunos sentados em círculo em volta do tabuleiro gigante, com pernas cruzadas. professor coloca o cavalo em uma casa no meio do tabuleiro, fala dois nomes, e os mesmos tem que levantar rapidamente e se posicionar em uma casa onde 0 cavalo ataca. 


\begin{tabular}{|c|c|c|c|c|}
\hline - Aula 10 & $\begin{array}{l}\text { - Aprender } \\
\text { movimentação } \\
\text { e captura do } \\
\text { cavalo. }\end{array}$ & $\begin{array}{l}\text { - Explicar sobre a } \\
\text { movimentação } \\
\text { captura com o cavalo. } \\
\text { - Explicar diferenças } \\
\text { entre movimentação e } \\
\text { captura entre as peças } \\
\text { já estudadas. } \\
\text { - Ressaltar a importância } \\
\text { e força do cavalo } \\
\text { contra dama. } \\
\text { - Salientar a habilidade } \\
\text { de salto do cavalo, } \\
\text { explicando a } \\
\text { movimentação sobre } \\
\text { as peças e } \\
\text { demonstrando erros } \\
\text { comuns cometidos. }\end{array}$ & $\begin{array}{l}\text { - Como o cavalo se movimenta? } \\
\text { - O cavalo pode pular qualquer } \\
\text { peça? } \\
\text { - O cavalo captura quem ele pula? } \\
\text { - Contra quem o cavalo é mais } \\
\text { forte? } \\
\text { - O cavalo tem o mesmo valor de } \\
\text { outra peça, que peça é essa? } \\
\text { - Quantas peças o cavalo pode } \\
\text { capturar de cada vez? Se ele } \\
\text { pular sobre três peças diferentes, } \\
\text { qual delas ele captura? }\end{array}$ & $\begin{array}{l}\text { - Jogo Cavalo Rápido: } \\
\text { alunos sentados em } \\
\text { círculo em volta do } \\
\text { tabuleiro gigante, } \\
\text { com pernas } \\
\text { cruzadas. } \\
\text { professor coloca o } \\
\text { cavalo em uma casa } \\
\text { no meio do tabuleiro, } \\
\text { fala dois nomes, e os } \\
\text { mesmo tem que } \\
\text { levantar rapidamente } \\
\text { e se posicionar em } \\
\text { uma casa onde o } \\
\text { cavalo ataca. }\end{array}$ \\
\hline - Aula 11 & $\begin{array}{l}\text { - Revisar } \\
\text { movimentação } \\
\text { e captura. }\end{array}$ & $\begin{array}{l}\text { - Ressaltar finalização } \\
\text { do tema movimentação } \\
\text { e captura. } \\
\text { - Demonstrar situações } \\
\text { de movimentação e } \\
\text { captura irregulares. } \\
\text { - Reforçar sobre erros } \\
\text { comuns. } \\
\text { - Verificar alunos com } \\
\text { dificuldade, erros } \\
\text { comuns da turma, } \\
\text { dúvidas ainda não } \\
\text { sanadas. }\end{array}$ & $\begin{array}{l}\text { - Quantas casas peão se } \\
\text { movimenta? E a dama? E o } \\
\text { cavalo? } \\
\text { - Cavalo pode capturar outro } \\
\text { cavalo? } \\
\text { - Qual peça pula? Quantas peças } \\
\text { podem andar na diagonal? } \\
\text { - Como a torre captura? E como } \\
\text { ela se movimenta? } \\
\text { - Quem é melhor? Uma dama ou } \\
\text { uma torre? } \\
\text { - Peão captura para trás? E para } \\
\text { frente? }\end{array}$ & $\begin{array}{l}\text { - Jogos em dupla, } \\
\text { utilização do tabuleiro } \\
\text { gigante. }\end{array}$ \\
\hline - Aula 12 & 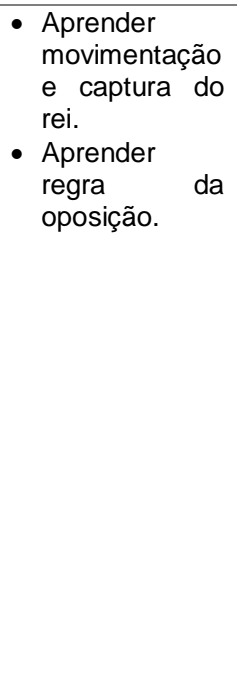 & $\begin{array}{l}\text { - Explicar sobre a } \\
\text { movimentação } \\
\text { captura com o rei. } \\
\text { - Explicar diferenças } \\
\text { entre movimentação e } \\
\text { captura entre as peças } \\
\text { já estudadas. } \\
\text { - Ressaltar a regra de } \\
\text { que o rei não pode ser } \\
\text { capturado. } \\
\text { - Explicar } \\
\text { oposição, sobre } \\
\text { ênfase ao fato de que o } \\
\text { rei não pode ser expor } \\
\text { ao xeque. } \\
\text { - Dar ênfase à atitude a } \\
\text { ser tomada diante do } \\
\text { erro (ao constatar o } \\
\text { erro, deve-se voltar e } \\
\text { corrigir o lance } \\
\text { incorreto). }\end{array}$ & $\begin{array}{l}\text { - Rei se movimenta quantas } \\
\text { casas? Em que direção? } \\
\text { - O rei pode capturar qualquer } \\
\text { peça? } \\
\text { - O rei pode ser capturado? } \\
\text { - O rei pode chegar perto do outro } \\
\text { rei? Se não, por quê? } \\
\text { - O que acontece quando o rei se } \\
\text { movimenta para uma casa onde } \\
\text { pode ser capturado? } \\
\text { - Que atitude se deve tomar } \\
\text { quando seu adversário erra e põe } \\
\text { o seu próprio rei em xeque? }\end{array}$ & $\begin{array}{l}\text { - Guerra dos tronos: } \\
\text { com as peças } \\
\text { gigantes, convidar } \\
\text { dois alunos a } \\
\text { comandarem os reis. } \\
\text { Cada rei fica em uma } \\
\text { casa oposta no } \\
\text { tabuleiro, onde cada } \\
\text { um deve chegar a } \\
\text { seu trono antes do } \\
\text { outro. }\end{array}$ \\
\hline - Aula 13 & $\begin{array}{l}\text { - Aprender } \\
\text { movimentação } \\
\text { e captura do } \\
\text { rei. } \\
\text { - Aprender } \\
\text { regra da } \\
\text { oposição. }\end{array}$ & $\begin{array}{l}\text { - Explicar sobre a } \\
\text { movimentação } \\
\text { captura com o rei. } \\
\text { - Reforçar } \\
\text { impossibilidade do rei } \\
\text { se movimentar para } \\
\text { situação de xeque, } \\
\text { obrigatoriedade de se } \\
\text { sair do xeque e regra } \\
\text { da oposição. } \\
\text { - Perguntas direcionadas } \\
\text { ou livres sobre quais } \\
\text { casas o rei pode se } \\
\text { movimentar, utilizando } \\
\text { tabuleiro magnético. }\end{array}$ & $\begin{array}{l}\text { - Rei se movimenta quantas } \\
\text { casas? Em que direção? } \\
\text { - O rei pode capturar qualquer } \\
\text { peça? } \\
\text { - O rei pode ser capturado? } \\
\text { - O rei pode chegar perto do outro } \\
\text { rei? Se não, por quê? } \\
\text { - O que acontece quando o rei se } \\
\text { movimenta para uma casa onde } \\
\text { pode ser capturado? } \\
\text { - Que atitude se deve tomar } \\
\text { quando seu adversário erra e põe } \\
\text { o seu próprio rei em xeque? }\end{array}$ & $\begin{array}{l}\text { - Guerra dos tronos: } \\
\text { com as peças } \\
\text { gigantes, convidar } \\
\text { dois alunos a } \\
\text { comandarem os reis. } \\
\text { Cada rei fica em uma } \\
\text { casa oposta no } \\
\text { tabuleiro, onde cada } \\
\text { um deve chegar a } \\
\text { seu trono antes do } \\
\text { outro. }\end{array}$ \\
\hline
\end{tabular}




\begin{tabular}{|c|c|c|c|c|}
\hline - Aula 14 & $\begin{array}{l}\text { Aprender } \\
\text { sobre xeque e } \\
\text { xeque-mate. }\end{array}$ & $\begin{array}{l}\text { - Explicar sobre o que é } \\
\text { xeque e xeque-mate. } \\
\text { - Explicar sobre as } \\
\text { diferenças entre um e } \\
\text { outro. } \\
\text { - Demonstrar várias } \\
\text { situações de xeque e } \\
\text { de xeque-mate. } \\
\text { - Iniciar conceitos de } \\
\text { defesa, contra-ataque e } \\
\text { fuga. }\end{array}$ & $\begin{array}{l}\text { - O que é xeque? E xeque-mate? } \\
\text { - Qual a diferença entre xeque e } \\
\text { xeque-mate? } \\
\text { - Xeque-mate significa capturar o } \\
\text { rei adversário? } \\
\text { - Que modos existem para se } \\
\text { escapar de uma situação de } \\
\text { xeque? } \\
\text { - É obrigatório sair de uma } \\
\text { situação de xeque? E, se não } \\
\text { sair, o que acontece? } \\
\text { - É obrigatório falar xeque? }\end{array}$ & $\begin{array}{l}\text { - Fuga do xeque: O } \\
\text { professor monta uma } \\
\text { situação de xeque, } \\
\text { onde cada aluno } \\
\text { deve apresentar o } \\
\text { melhor método para } \\
\text { se escapar de tal } \\
\text { situação. }\end{array}$ \\
\hline - Aula 15 & $\begin{array}{l}\text { - Aprender } \\
\text { sobre } \\
\text { métodos de } \\
\text { defesa contra } \\
\text { o xeque. }\end{array}$ & $\begin{array}{l}\text { - Revisar conceito de } \\
\text { xeque e xeque-mate. } \\
\text { - Explicar sobre os } \\
\text { métodos de se escapar } \\
\text { de uma situação de } \\
\text { xeque: contra-ataque, } \\
\text { defesa e fuga. } \\
\text { - Demonstrar várias } \\
\text { situações onde se } \\
\text { possam utilizar tais } \\
\text { métodos para se } \\
\text { escapar do xeque. }\end{array}$ & $\begin{array}{l}\text { - O que é xeque? E xeque-mate? } \\
\text { - Qual a diferença entre xeque e } \\
\text { xeque-mate? } \\
\text { - Quais são os modos de se } \\
\text { escapar do xeque? } \\
\text { - Qual o primeiro método que se } \\
\text { deve considerar para fugir do } \\
\text { xeque? E qual o segundo? E } \\
\text { terceiro? }\end{array}$ & $\begin{array}{l}\text { - Mate-se: alunos } \\
\text { sentados em círculo } \\
\text { em volta do tabuleiro } \\
\text { gigante, com pernas } \\
\text { cruzadas. } \\
\text { professor coloca } \\
\text { algumas peças no } \\
\text { tabuleiro, e pede a } \\
\text { cada aluno para se } \\
\text { colocar em situação } \\
\text { de xeque-mate. }\end{array}$ \\
\hline - Aula 16 & $\begin{array}{l}\text { - Aprender } \\
\text { sobre } \\
\text { métodos } \\
\text { fuga } \\
\text { xeque. }\end{array}$ & $\begin{array}{l}\text { - Reforçar o conceito de } \\
\text { métodos de fuga do } \\
\text { xeque: CBF. } \\
\text { - Reforçar no conceito } \\
\text { bloquear. } \\
\text { - Ensinar a ordem } \\
\text { correta a ser seguida. } \\
\text { - Que tipos de peças } \\
\text { utilizar para bloquear. } \\
\text { - Demonstrar situações } \\
\text { onde bloquear não vale } \\
\text { a pena. }\end{array}$ & $\begin{array}{l}\text { - Bloquear é o melhor jeito de se } \\
\text { escapar de um xeque? } \\
\text { - Bloquear é sempre melhor do } \\
\text { que fugir? } \\
\text { - Quando bloquear não vale a } \\
\text { pena? E quando vale? } \\
\text { - Quais as melhores peças que } \\
\text { devem ser utilizadas para } \\
\text { bloquear? } \\
\text { - Fugir é o pior jeito de se escapar } \\
\text { de um xeque? } \\
\text { - Bloquear e capturar são sempre } \\
\text { melhores do que fugir? } \\
\text { - Quando fugir é melhor do que } \\
\text { bloquear ou capturar? } \\
\text { Quais as melhores direções para } \\
\text { se fugir? }\end{array}$ & $\begin{array}{l}\text { - Fuga do xeque: o } \\
\text { professor monta uma } \\
\text { situação de xeque, } \\
\text { onde cada aluno } \\
\text { deve apresentar o } \\
\text { melhor método para } \\
\text { se escapar de tal } \\
\text { situação (priorizar } \\
\text { situações envolvendo } \\
\text { bloqueio). }\end{array}$ \\
\hline - Aula 17 & $\begin{array}{l}\text { - Aprender } \\
\text { sobre xeque e } \\
\text { xeque-mate. }\end{array}$ & $\begin{array}{l}\text { - Reforçar o conceito de } \\
\text { métodos de fuga do } \\
\text { xeque: CBF } \\
\text { - Reforçar no conceito } \\
\text { fugir. } \\
\text { - Ensinar a ordem } \\
\text { correta a ser seguida. } \\
\text { - Qual a melhor direção } \\
\text { a se fugir. } \\
\text { - Demonstrar situações } \\
\text { onde fugir é melhor que } \\
\text { os outros dois } \\
\text { métodos. }\end{array}$ & $\begin{array}{l}\text { - } \text { Bloquear é o melhor jeito de se } \\
\text { escapar de um xeque? } \\
\text { - Bloquear é sempre melhor do } \\
\text { que fugir? } \\
\text { - Quando bloquear não vale a } \\
\text { pena? E quando vale? } \\
\text { - Quais as melhores peças que } \\
\text { devem ser utilizadas para } \\
\text { bloquear? } \\
\text { - Fugir é o pior jeito de se escapar } \\
\text { de um xeque? } \\
\text { - Bloquear e capturar são sempre } \\
\text { melhores do que fugir? } \\
\text { - Quando fugir é melhor do que } \\
\text { bloquear ou capturar? } \\
\text { - Quais as melhores direções para } \\
\text { se fugir? }\end{array}$ & $\begin{array}{l}\text { - Fuga do xeque: o } \\
\text { professor monta uma } \\
\text { situação de xeque, } \\
\text { em que cada aluno } \\
\text { deve apresentar o } \\
\text { melhor método para } \\
\text { se escapar de tal } \\
\text { situação (priorizar } \\
\text { situações envolvendo } \\
\text { fuga). }\end{array}$ \\
\hline
\end{tabular}




\begin{tabular}{|c|c|c|c|c|}
\hline - Aula 18 & $\begin{array}{l}\text { - Aprender } \\
\text { sobre xeque e } \\
\text { xeque-mate } \\
\text { utilizando } \\
\text { exercícios de } \\
\text { mate em um. }\end{array}$ & $\begin{array}{l}\text { - Ensinar conceito de } \\
\text { problemas "mate em } \\
\text { um" } \\
\text { - Sequência de de } \\
\text { raciocínio a ser seguida } \\
\text { para visualizar o mate. } \\
\text { - Dicas gerais sobre } \\
\text { como visualizar o mate } \\
\text { mais rapidamente. }\end{array}$ & $\begin{array}{l}\text { - O que é um exercício de "mate } \\
\text { em um"? } \\
\text { - Qual a importância de se praticar } \\
\text { tais exercícios? } \\
\text { - Qual o caminho de raciocínio que } \\
\text { se deve seguir para enxergar } \\
\text { melhor a solução de um exercício } \\
\text { de "mate em um"? } \\
\text { - Qual o primeiro ponto a ser } \\
\text { observado em um exercício de } \\
\text { mate em um"? }\end{array}$ & $\begin{array}{l}\text { - Mate em um no } \\
\text { tabuleiro gigante, } \\
\text { onde cada aluno } \\
\text { representa a peça } \\
\text { que irá dar mate. }\end{array}$ \\
\hline - Aula 19 & $\begin{array}{l}\text { - Aprender } \\
\text { sobre falta. }\end{array}$ & $\begin{array}{l}\text { - Definir o que é falta. } \\
\text { - Demonstrar várias } \\
\text { situações em que faltas } \\
\text { ocorrem. } \\
\text { - Demonstrar os passos } \\
\text { a serem tomados } \\
\text { quando uma situação } \\
\text { de falta ocorre. } \\
\text { - Reforçar o fato de que } \\
\text { a falta só é } \\
\text { contabilizada após o } \\
\text { reclame do jogador. }\end{array}$ & $\begin{array}{l}\text { - O que é falta? } \\
\text { - Quais situações são } \\
\text { caracterizadas como faltas? } \\
\text { - O que se deve fazer quando você } \\
\text { comete uma falta? } \\
\text { - O que se deve fazer quando o } \\
\text { seu adversário comete uma } \\
\text { falta? } \\
\text { - Com quantas faltas se perde o } \\
\text { jogo? } \\
\text { - Se uma falta aconteceu a duas } \\
\text { rodadas atrás, ela ainda vale? }\end{array}$ & $\begin{array}{l}\text { - Mate-se: alunos } \\
\text { sentados em círculo } \\
\text { em volta do tabuleiro } \\
\text { gigante, com pernas } \\
\text { cruzadas. coloca } \\
\text { professor peças no } \\
\text { algumas peçar a pede a } \\
\text { tabuleiro, e para se } \\
\text { cada aluno para } \\
\text { colocar em situação } \\
\text { de xeque-mate. }\end{array}$ \\
\hline - Aula 20 & $\begin{array}{l}\text { - Aprender } \\
\text { sobre mates } \\
\text { básicos } \\
\text { (escada). }\end{array}$ & $\begin{array}{l}\text { - Definir o que é o mate } \\
\text { da escada, } \\
\text { enaltecendo suas } \\
\text { características e sua } \\
\text { alta incidência em } \\
\text { jogos. } \\
\text { - Demonstrar o papel de } \\
\text { cada peça na posição } \\
\text { de mate, demonstrando } \\
\text { a peça que ataca e a } \\
\text { peça que } \\
\text { cerca/defende. qua }\end{array}$ & $\begin{array}{l}\text { - Que peças são utilizadas no } \\
\text { mate da escada? } \\
\text { - Como as peças devem estar } \\
\text { posicionadas? } \\
\text { - Quais métodos de escape do } \\
\text { xeque são possíveis numa } \\
\text { situação de mate da escada? }\end{array}$ & $\begin{array}{l}\text { - Mate da escada no } \\
\text { tabuleiro gigante, } \\
\text { com alunos no lugar } \\
\text { das peças. }\end{array}$ \\
\hline
\end{tabular}


APÊNDICE B - Atividade de reforço destinadas ao GC1

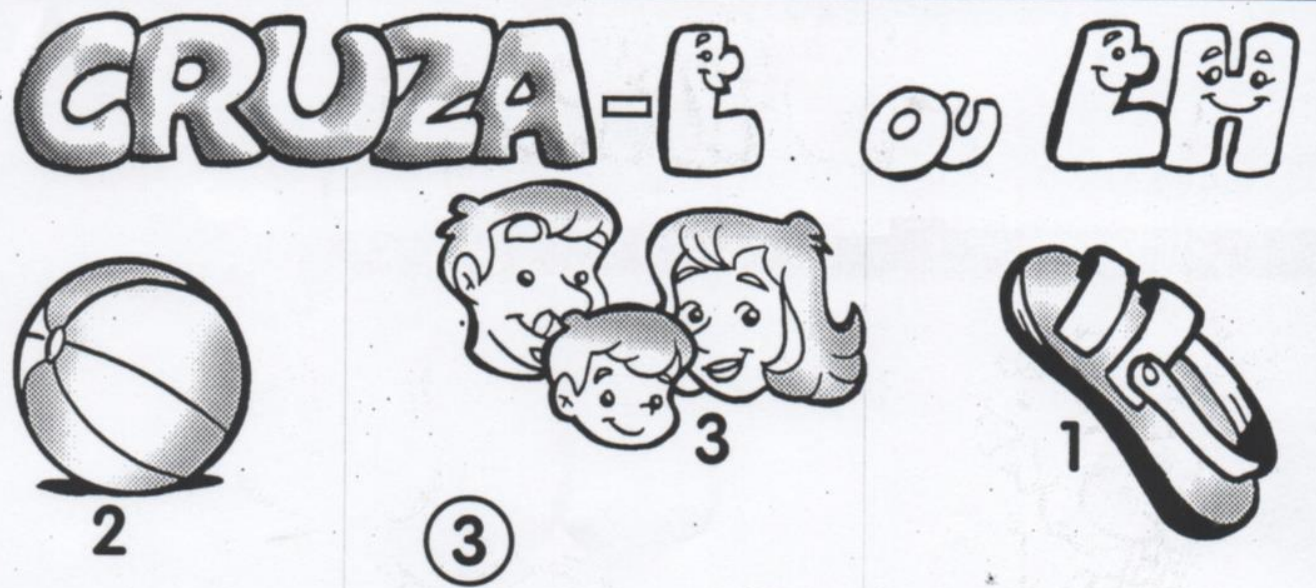

(3)

(1)

(2) 0000

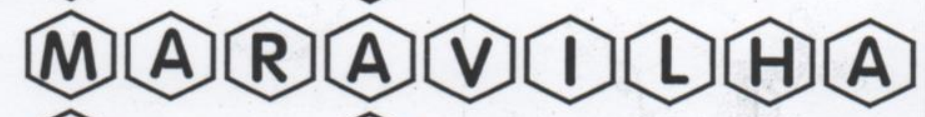

(4)

0

(5) 00000

(6)

(6) 400000

$\ln _{5}$
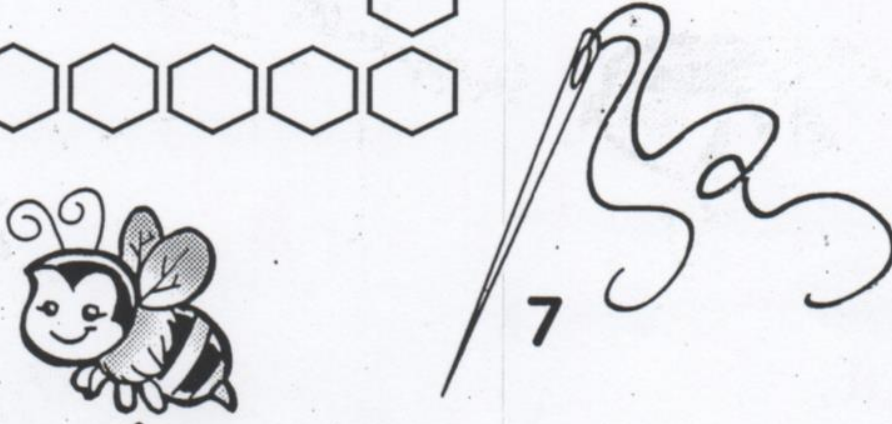

Respostas: 


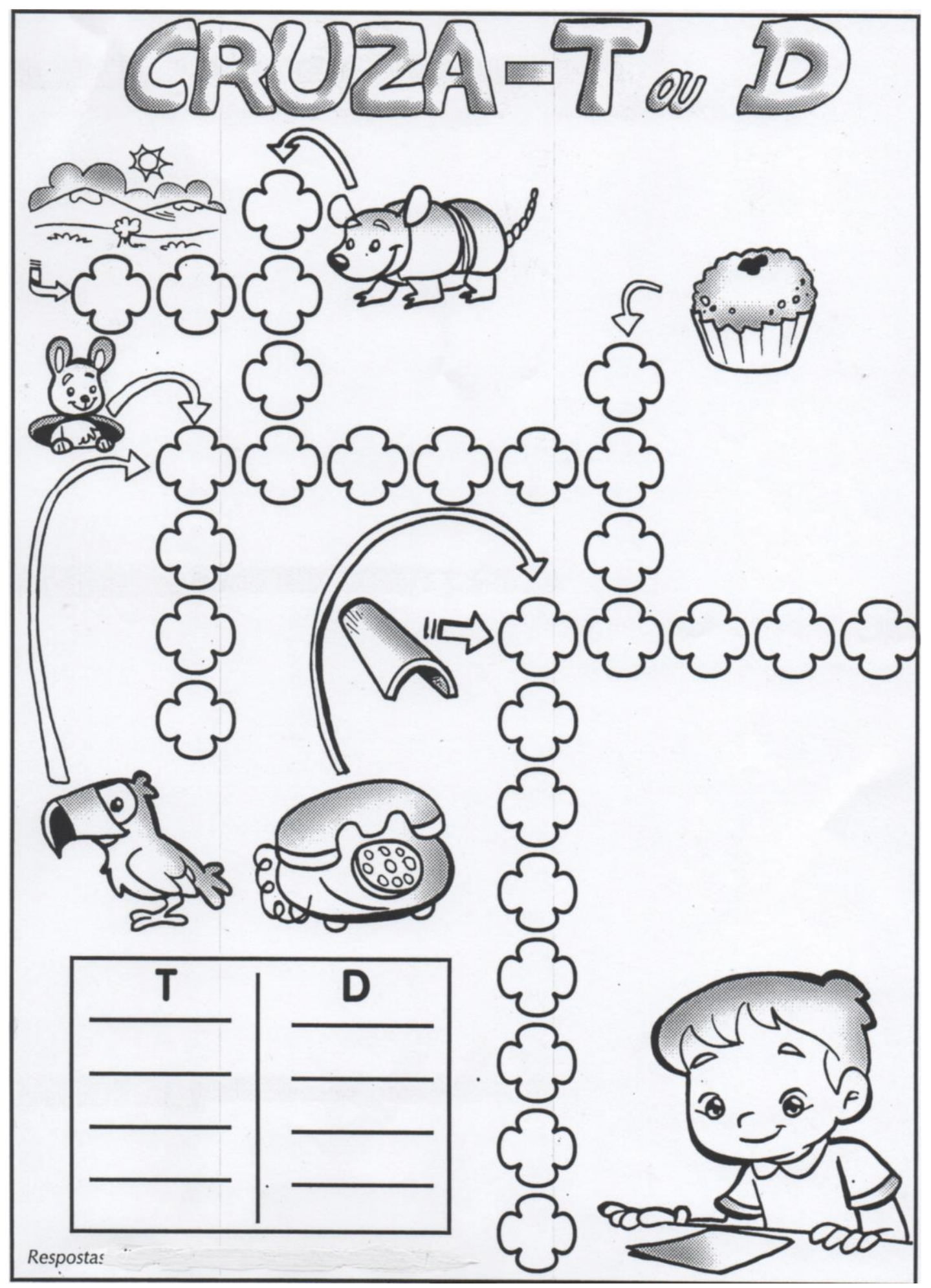




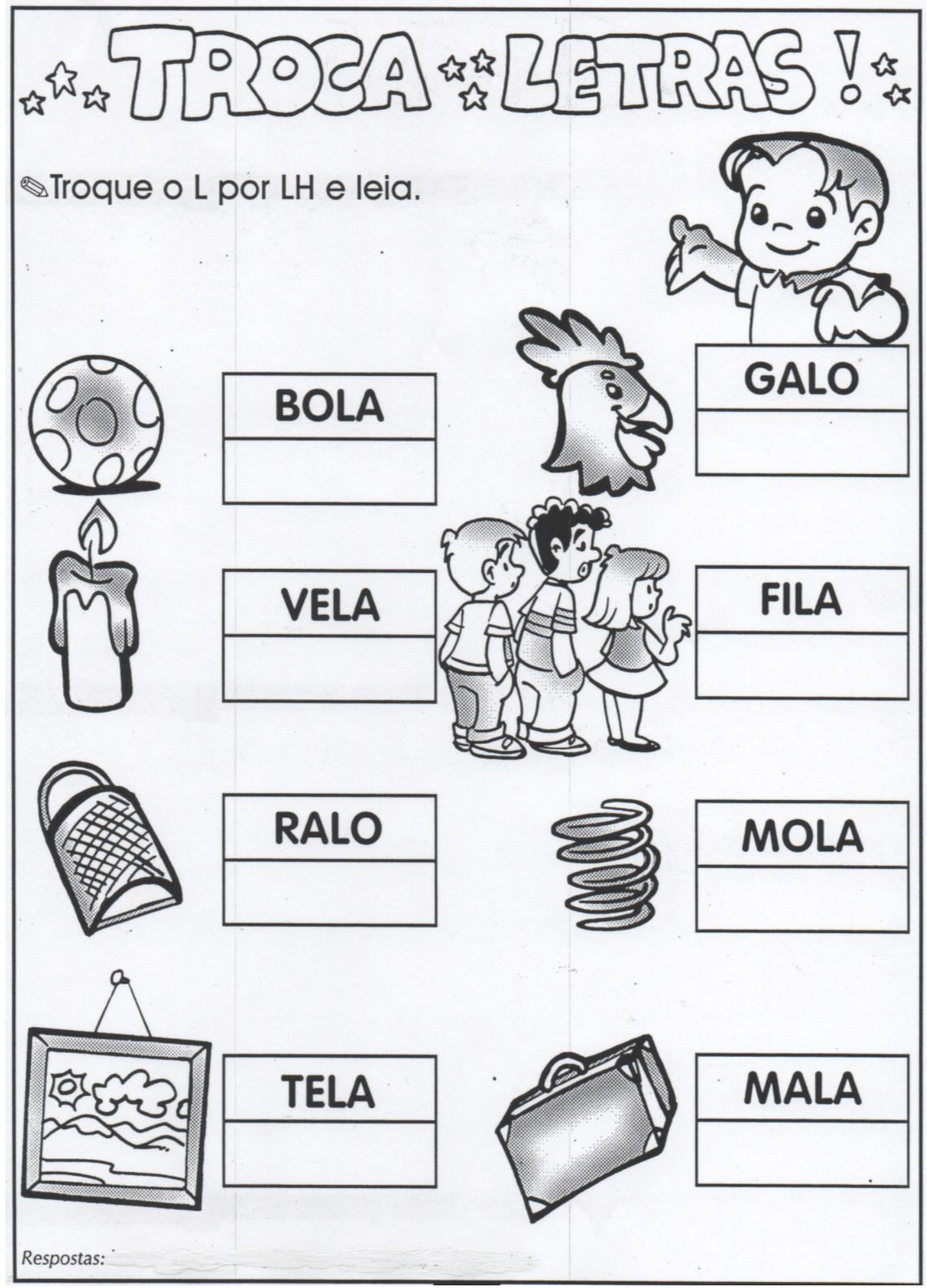




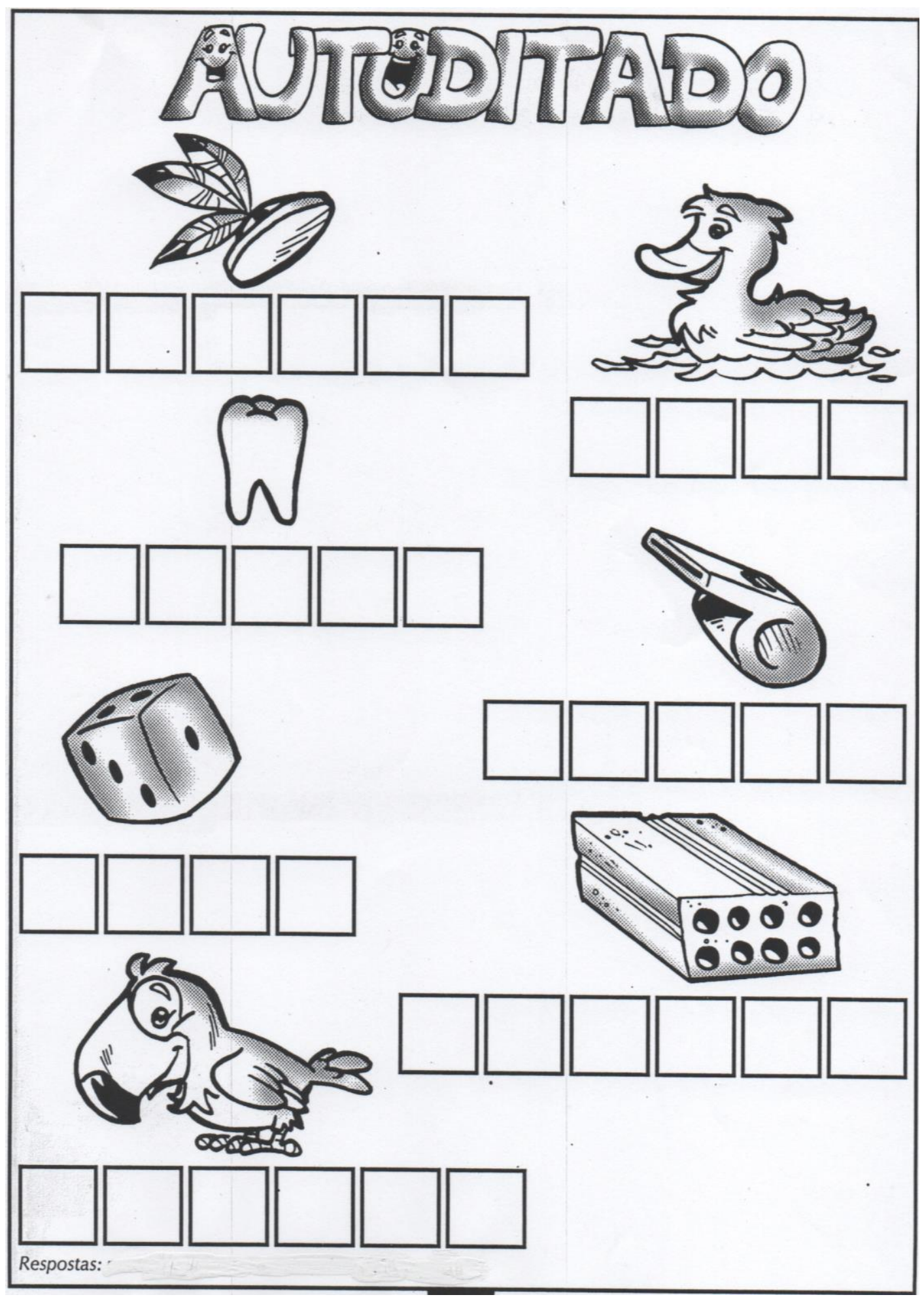




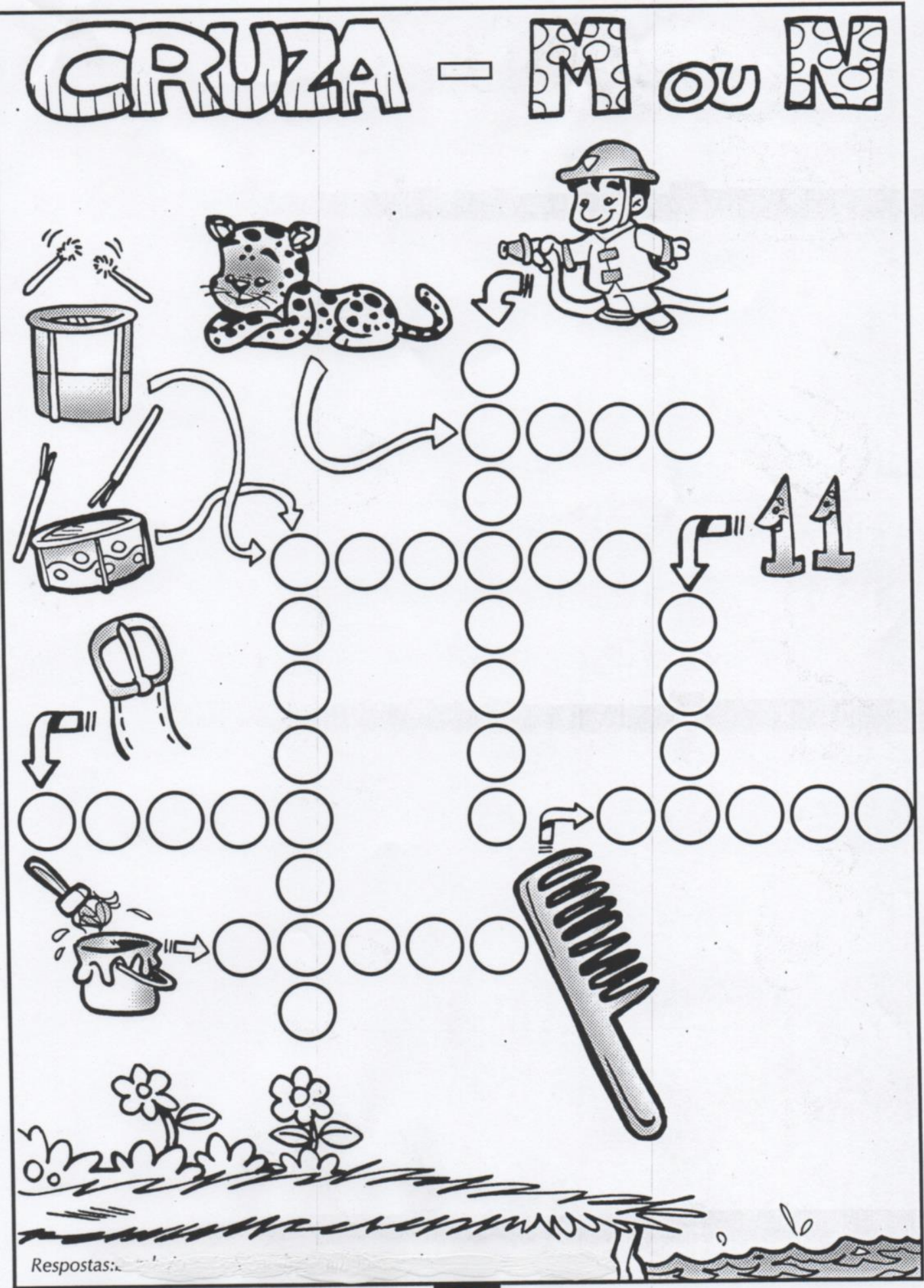




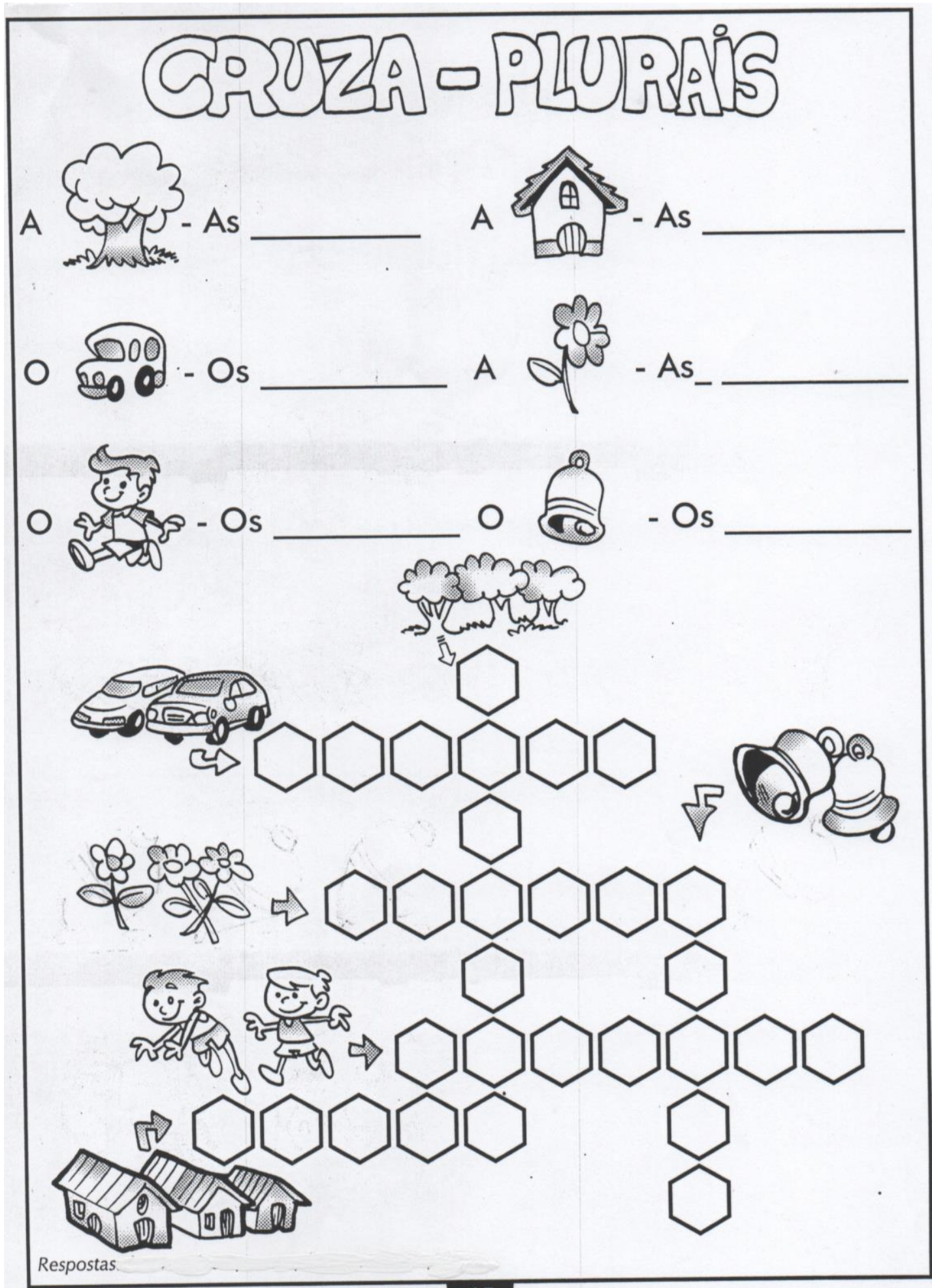




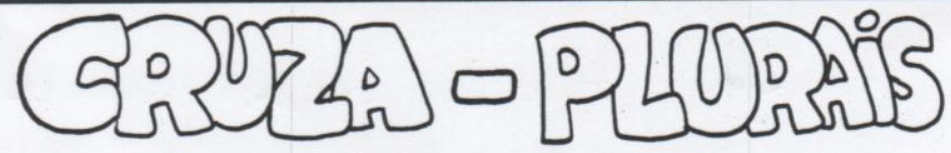

Q Complete com o plural:

O porco - Os

$O$ urso - Os

O cavalo - Os

O sapo - Os

O gato - Os

कि०

2

(2)

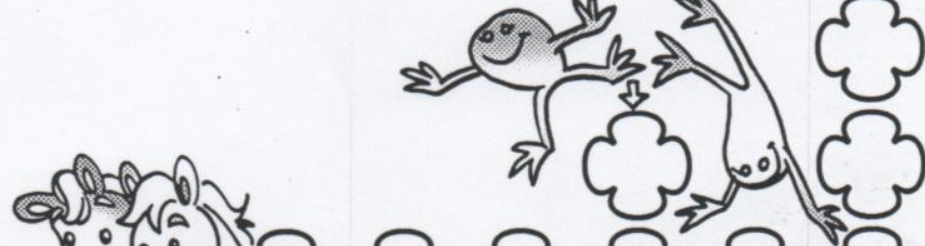

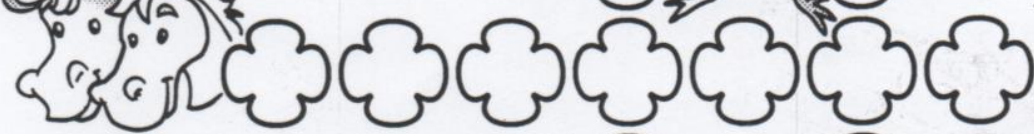

धु दु

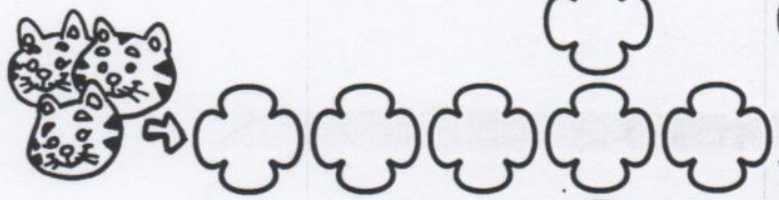

\&3

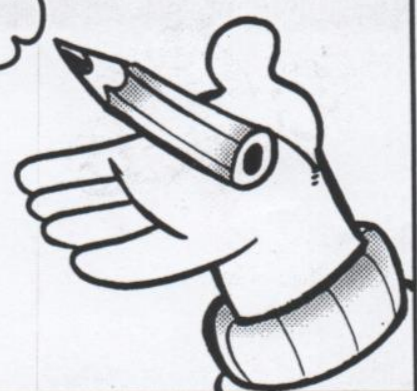


-Instruçoes:

Para brincar com o jogo dos 7 erros basta imprimir essa página, depois encontre os 7 erros que existem entre os desenhos abaixo. Marque-os com uma canetinha ou lápis para não perder a conta! Boa diversão!
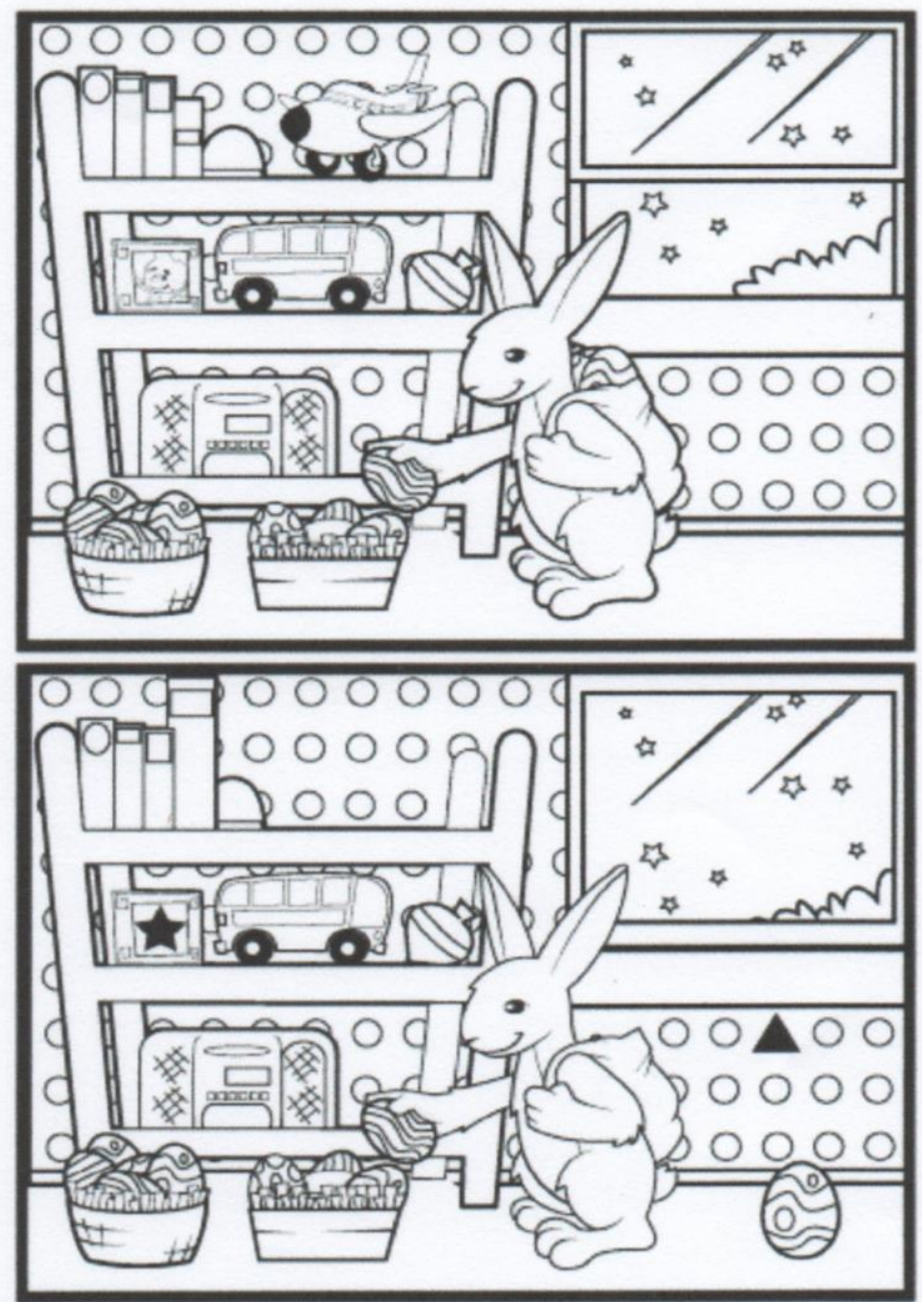


\section{Desafiande você!}

Descubra os preços e complete os quadros:

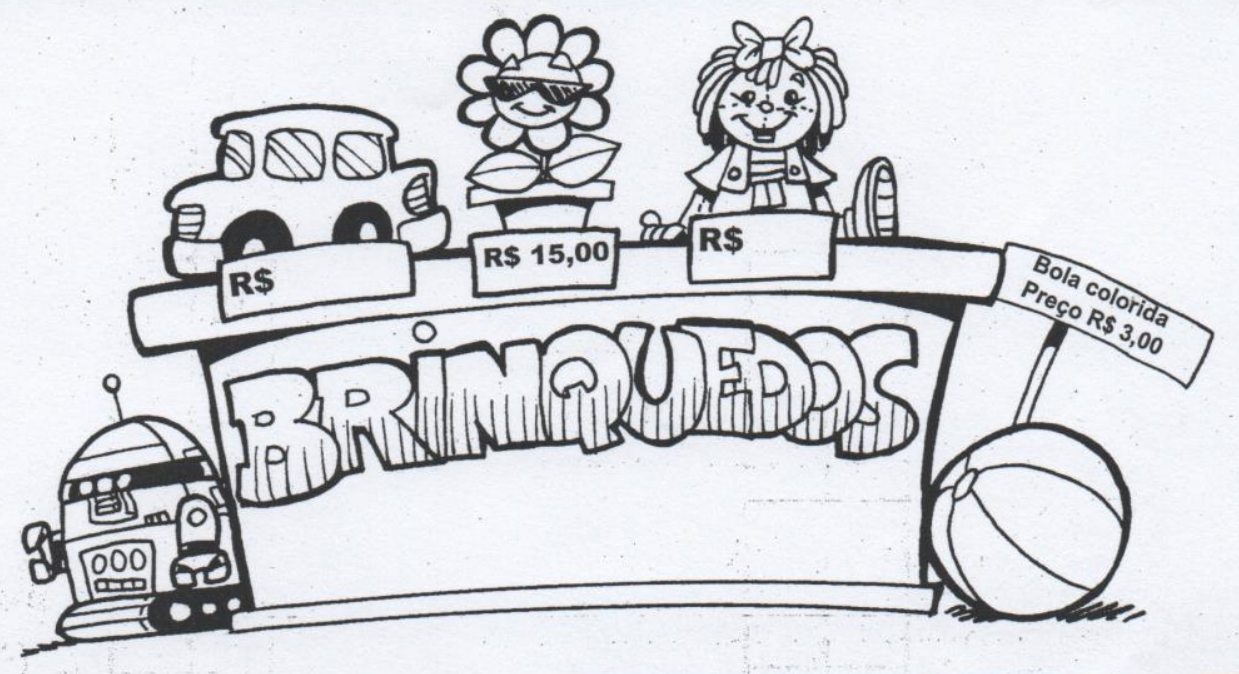

- O preço da boneca é o triplo do preço da bola. Qual é o preço da boneca?

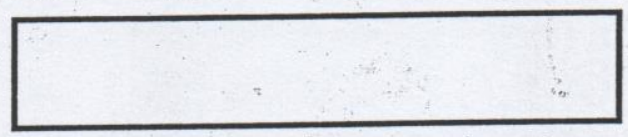

- O carrinho custa o preço da boneca, mais a metade do preço da bola. Quanto custa o carrinho?

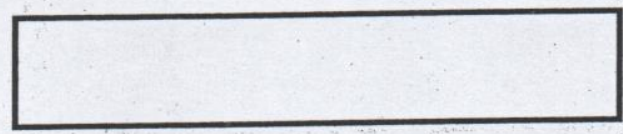

- Mamãe comprou dois carrinhos. Ela pagou

- Sula comprou uma flor e uma bola. Ela gastou

\begin{tabular}{|c|}
\hline OPERAÇÕES \\
\hline \\
\end{tabular}

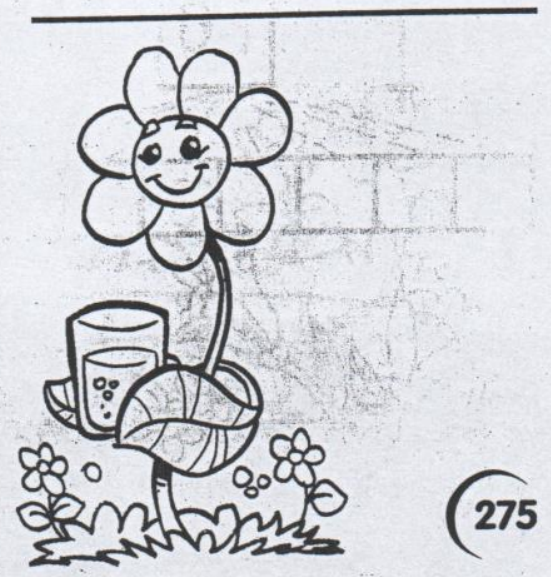




\section{Desafiande você}

- Um elevador saiu do andar térreo com 2 adultos, 3 crianças e o ascensorista.

- Na primeira parada, que foi no $2^{\circ}$ andar, desceram quatro pessoas.

- Na segunda parada, entraram 2 pessoas e não desceu ninguém.

- Na terceira parada só entrou uma pessoa.

- Na última parada desceram 4 pessoas e o elevador voltou ao térreo trazendo quem permaneceu.

- Quantas pessoas ficaram no elevador?

- Quem é essa pessoa?
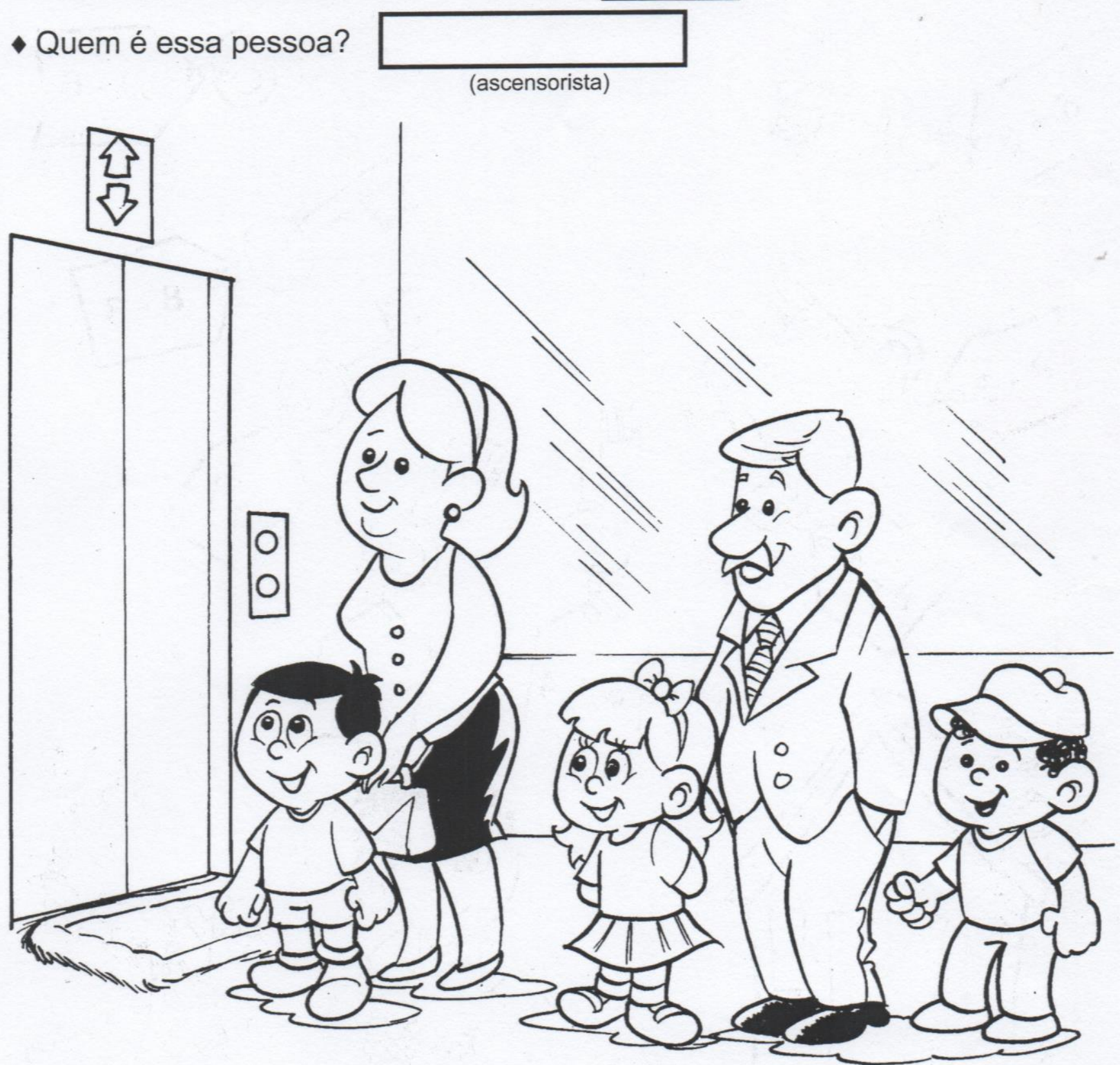


\section{APÊNDICE C - Termo de Consentimento Livre e Esclarecido}

\section{Termo de Consentimento Livre e Esclarecido}

Você está sendo convidado a participar da pesquisa "A influência da prática do xadrez no raciocínio infantil", de responsabilidade de Wellington Aguiar de Melo, aluno de mestrado da Universidade de Brasília. O objetivo desta pesquisa é analisar o desempenho de crianças, que praticaram xadrez por 10 semanas, em um teste de raciocínio e comparar seu desempenho com o de crianças que frequentaram o reforço escolar, a fim de verificar a existência de diferenças significativas entre o desempenho de ambos os grupos. Assim, gostaria de consultá-lo(a) sobre seu interesse e disponibilidade de cooperar com a pesquisa.

Você receberá todos os esclarecimentos necessários antes, durante e após a finalização da pesquisa, e Ihe asseguro que o seu nome não será divulgado, sendo mantido o mais rigoroso sigilo mediante a omissão total de informações que permitam identificá-lo(a). Os dados provenientes de sua participação na pesquisa, tais como questionários, testes ou entrevistas, ficarão sob a guarda do pesquisador responsável pela pesquisa.

A coleta de dados será realizada por meio de um teste de raciocínio denominado "TESTE NÃO VERBAL DE RACIOCÍNIO INFANTIL", em que cada criança deverá completar uma figura simples, encontrando entre as opções qual é o pedaço que falta para completar a figura. É para estes procedimentos que você está sendo convidado a participar. Sua participação na pesquisa não implica em nenhum risco.

Espera-se com esta pesquisa que as crianças participantes do estudo obtenham um incremento em seus índices de raciocínio, mediante a prática do xadrez ou pelo reforço escolar.

Sua participação é voluntária e livre de qualquer remuneração ou benefício. Você é livre para recusarse a participar, retirar seu consentimento ou interromper sua participação a qualquer momento. A recusa em participar não irá acarretar qualquer penalidade ou perda de benefícios.

Se você tiver qualquer dúvida em relação à pesquisa, você pode me contatar através do telefone 61 8168-4530 ou pelo e-mail xadrezw@gmail.com.

A equipe de pesquisa garante que os resultados do estudo serão devolvidos aos participantes por meio de um relatório contendo todos os dados obtidos, podendo ser publicados posteriormente na comunidade científica.

Este documento foi elaborado em duas vias: uma ficará com o pesquisador responsável pela pesquisa e a outra com o(a) senhor(a). 


\section{APÊNDICE D - Termo de aceite institucional}

\section{ACEITE INSTITUCIONAL}

O Sr.

está de

acordo com a realização da pesquisa A influência da prática do xadrez no raciocínio infantil, de responsabilidade do pesquisador Wellington Aguiar de Melo aluno de Mestrado no Departamento de Educação da Universidade de Brasília, realizado sob orientação de Prof. Dr. Antônio Villar Marques de Sá, após revisão e aprovação pelo Comitê de Ética em Pesquisa do Instituto de Ciências Humanas da Universidade de Brasília - CEP/IH.

O estudo tem como por objetivo avaliar se a prática do xadrez tem influência no desenvolvimento de habilidades cognitivas de crianças, em específico do raciocínio. A pesquisa terá a duração de 32 aulas (16 semanas) com previsão de início em março de 2014 e término em junho de 2014.

Eu,

declaro conhecer e cumprir as Resoluções Éticas Brasileiras, em especial a Resolução CNS 196/96. Esta instituição está ciente de suas co-responsabilidades como instituição coparticipante do presente projeto de pesquisa, e de seu compromisso no resguardo da segurança e bem-estar dos sujeitos de pesquisa nela recrutados, dispondo de infra-estrutura necessária para a garantia de tal segurança e bem-estar.

Brasília-DF, 17 de Março de 2014 